Florida International University FIU Digital Commons

\title{
Ant-diarrheal Plants of Central Anatolia: Do They Inhibit Diarrhea-causing Bacteria?
}

Janna L. Rose

Florida International University, jannarose00@yahoo.com

DOI: $10.25148 /$ etd.FI11072601

Follow this and additional works at: https://digitalcommons.fiu.edu/etd

\section{Recommended Citation}

Rose, Janna L., "Ant-diarrheal Plants of Central Anatolia: Do They Inhibit Diarrhea-causing Bacteria?" (2011). FIU Electronic Theses and Dissertations. 430.

https://digitalcommons.fiu.edu/etd/430 


\title{
FLORIDA INTERNATIONAL UNIVERSITY
}

\author{
Miami, Florida
}

ANTI-DIARRHEAL PLANTS OF CENTRAL ANATOLIA:

DO THEY INHIBIT DIARRHEA-CAUSING BACTERIA?

A dissertation submitted in partial fulfillment of the

requirements for the degree of DOCTOR OF PHILOSOPHY

in

\section{BIOLOGY}

by

Janna Leann Rose 
To: Dean Kenneth Furton

College of Arts and Sciences

This dissertation, written by Janna Leann Rose, and entitled Anti-Diarrheal Plants of Central Anatolia: Do they Inhibit Diarrhea-causing Bacteria?, having been approved in respect to style and intellectual content, is referred to you for judgment.

We have read this dissertation and recommend that it be approved.

Suzanne Koptur

Laura Ogden

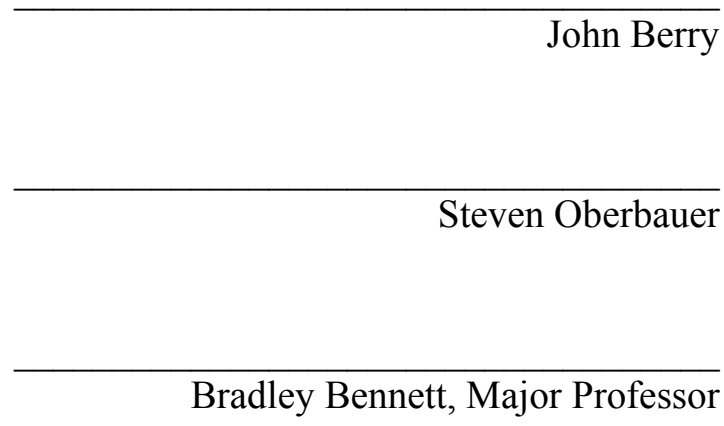

Date of Defense: June 27, 2011

The dissertation of Janna Leann Rose is approved.

Dean Kenneth Furton
College of Arts and Sciences

Florida International University, 2011 
C Copyright 2011 by Janna Leann Rose

All rights reserved. 


\section{DEDICATION}

For my brother, Michael, who never got over his shock and awe of nature.

May I spread that contagious sense of wonder to the people in my life. 


\section{ACKNOWLEDGMENTS}

I am honored to have worked with many erudite specialists and motivating professors during the course of my dissertation research. In the laboratories at Florida International University, beginning with the Center for Ethnobiology and Natural Products Research (CENaP), I received detailed instruction from my advisor, Brad Bennett, his colleagues Horacio Priestap and Martin Quirke, and my dear graduate school sisters, Cassandra Quave and Angelle Bullard-Roberts.

My dissertation committee was always there for me, even in the last minutes before I departed for Brazil or Turkey. With much appreciation, Laura Ogden kept me grounded in my anthropological roots while Suzanne Koptur and Steve Oberbauer assisted in improving my plant ecology endeavors. John Berry helped me formulate questions pertaining to chemistry and offered the use of his laboratory and materials for the cytotoxicity screening, for which I am very grateful.

Charles Bigger, Aileen Landry, Esther Lopez, and other dedicated members of the MBRS office helped me in countless ways (NIH NIGMS R25 GM 061347). Their assistance made my FIU graduate days much smoother and allowed me to give presentations at several conferences. Without a stipend from the MBRS/RISE program, I would not have been able to attend graduate school, much less complete my research. Receiving the Biomedical Research Initiative summer research award significantly augmented my doctoral studies and end results.

In Ankara, Turkey, with the assistance of the Fulbright Commission, I was able to work and live among Turkish villagers and my Turkish in-laws, to whom I am eternally grateful for their knowledge and hospitality. The professors and graduate students at Gazi University became my friends and my colleagues, and their assistance was necessary for 
the completion of my field and laboratory work. To Evrim Ölçer, Sema Demir, Ilhan Gürbüz, Berrin Özçelik, and Ekrem Sezik, I am very thankful for your cooperation. At the University of Miami, Drs. Lisa and Gary Plano graciously offered their assistance and some of their diarrhea-causing bacterial strains. At the University of Florida, Dr. Jodie Johnson assisted with the HPLC/UV/ESI-MSn Analysis of ellagic acid. Finally, I must acknowledge the unceasing support of my families - my Turkish family, my American family, and my Brazilian family. My mother and sister never stopped believing in me, even when the end never seemed in sight. My dad and stepmom wanted me to land a good job with dental insurance, and I hope to exceed their expectations one of these days. Gazi and Samia were both my inspiration and my strength. Please, Gazi, never stop your loving chatter. And yes, Samia-you can be anything you want to be, even a "plant doctor" like Mom. 


\begin{abstract}
OF THE DISSERTATION
ANTI-DIARRHEAL PLANTS OF CENTRAL ANATOLIA:

DO THEY INHIBIT DIARRHEA-CAUSING BACTERIA?
\end{abstract}

by

Janna Leann Rose

Florida International University, 2011

Miami, Florida

Professor Bradley Bennett, Major Professor

Infectious diarrhea results in 2 to 5 million deaths worldwide per year, and treatments that are safe, effective, and readily available are under investigation. The field of medicinal ethnobotany focuses on plants that are used by different cultural groups for treating various diseases and evaluates these plants for efficacy and cytotoxicity. In the present study, ethnobotanical research was conducted with Central Anatolian villagers in Turkey. Folk concepts and etiologies surrounding diarrhea were analyzed, as were salient plant-based remedies for diarrhea. Reviewing the literature, 91 plant species were described as anti-diarrheal in all of Turkey. In Central Anatolia, villagers described 35 species. For continued research via bactericidal and bacteriostatic bioassays, 15 plants were selected. Methanolic and aqueous extracts of medicinally used plant parts were evaluated for inhibitory properties against 10 diarrhea-causing bacteria in the first bioassay, and later 21 bacteria in a second assay utilizing spectrophotometry. The cytotoxic properties were also evaluated in an Alamar Blue Assay using HepG-2, PC-3, and SkMEL-5 human cell lines. While several extracts showed bactericidal and bacteriostatic properties, the methanolic extract of $R$. canina galls inhibited the most bacteria at the lowest concentrations. They were not cytotoxic. Thus, R. canina methanolic gall extracts were selected for bio-assay guided fractionation. Antibacterial 
activity was maintained in the third fraction which was composed of almost pure ellagic acid. The bioassay was repeated with standard ellagic acid, and the polyphenol retained potency in inhibiting multiple bacterial strains. Several other extracts showed promise for safe, effective anti-bacterial remedies for diarrhea. 
TABLE OF CONTENTS

CHAPTER

PAGE

I. DIARRHEAL DISEASE AND THE NEED FOR NEW

THERAPIES

Introduction

Plant-based Remedies for Diarrhea

Recent Highlights in Infectious Diarrhea Research

Anti-Diarrheal Plants of Central Anatolia, Turkey .....................................13

Dissertation Research

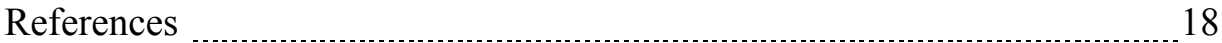

II. DISEASE CONCEPTS AND ETHNOBOTANY OF

DIARRHEAL DISEASES IN CENTRAL ANATOLIA

Introduction $\ldots \ldots \ldots$

The Field Site: Turkey

Methods

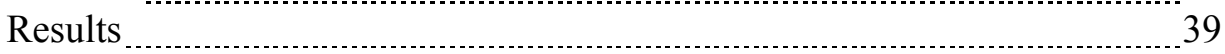

Discussion $\ldots \ldots$

Conclusions _......................................................................... 51

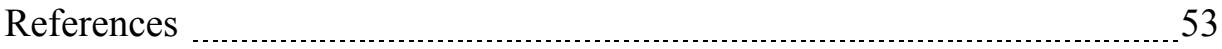

III. COMPARATIVE IN-VITRO BACTERICIDAL AND

BACTERIOSTATIC ACTIVITY OF ANTI-DIARRHEAL

PLANTS OF CENTRAL ANATOLIA 60

Introduction $\ldots$

Methods

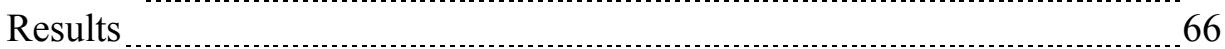

Discussion 68

Conclusions

Acknowledgments

References

IV. BACTERIAL INHIBITION AND CYTOTOXIC

PROPERTIES OF PLANTS USED TO TREAT DIARRHEA _ 75

Introduction 76

Methods

Results

Discussion $\quad 89$

Conclusions

Acknowledgments

References

V. IDENTIFICATION OF ELLAGIC ACID AS THE

ANTI-BACTERIAL COMPONENT OF

ROSA CANINA L. (DOG ROSE) GALLS _..................................................

Introduction $\ldots$

Methods 
Results

104

Discussion $\ldots 109$

Conclusions

Acknowledgments

References

APPENDICES 118

VITA 


\section{LIST OF TABLES}

TABLE

PAGE

1. Demographic Results for Group Interview Participants 40

2. Common Names for Diarrhea 40

3. Ranked Salient Types of Diarrheal Disease 41

4. Ranked Causes of Diarrheal Disease (22 Total) 41

5. Ranked Treatments for Diarrheal Disease (44 Total) 43

6. Plants Collected from Outdoors 44

7. Codes Used for Methanol and Aqueous Extracts 63

8. Bacterial Strains and Brief Descriptions 65

9. Extracts with MBS's of $32 \mu \mathrm{g} / \mathrm{ml}$ or Less and the Inhibited Bacteria 66

10, MICs $(\mu \mathrm{g} / \mathrm{ml})$ of Six Extracts against Staphylococcus aureus 67

11. MICs $(\mu \mathrm{g} / \mathrm{ml})$ of Rosa canina Extracts against Vibrio cholerae 68

12. Plant Extracts Listed with Codes 78

13. Bacteria Strains Listed with Codes and Standards 80

14. Results of the Initial Bioassay Showing MICs $(\mu \mathrm{g} / \mathrm{ml})$ 84

15. $\mathrm{MIC}_{50}$ and $\mathrm{MIC}_{90}$ Values for Top 5 Extracts and 5 Antibiotics 85

16. Significant MICs $(\mu \mathrm{g} / \mathrm{ml})$ Statistically Analyzed 87

17. Results of Preliminary Alamar Blue Assay 88

18. Secondary Assay MICs $(\mu \mathrm{g} / \mathrm{ml})$ of Rosa canina extracts 106

19. Bioassay Results $(\mu \mathrm{g} / \mathrm{ml})$ using Standard Ellagic acid 109 


\section{LIST OF FIGURES}

FIGURE

PAGE

1. Map of Turkey

2. Survey Participants near Çamlıdere $\ldots \ldots \ldots$

3. Differing Growth Curve Patterns

4. MICs $(\mu \mathrm{g} / \mathrm{ml})$ of Rose Galls against Bacteria from First Assay _......................... 105

5. HPLC Chromatogram of the Methanolic R. canina Gall Extract _..................... 107

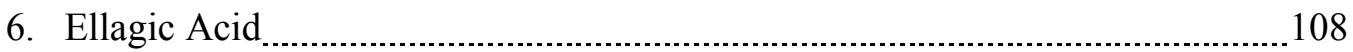




\section{Chapter I}

\section{DIARRHEAL DISEASE AND THE NEED FOR NEW THERAPIES}

\section{INTRODUCTION}

Acute gastrointestinal disease has many causes, yet the most intense and deadliest etiologies involve viruses and virulent bacteria and their toxins (Marcos and DuPont, 2007). Four billion people suffer from cases of acute diarrhea each year, leading to 2 million deaths (WHO and UNICEF, 2004). Children under the age of five account for 1.8 million of these deaths (UNICEF and WHO, 2009).

Although diarrheal disease affects billions of people, it is inadequately studied because of its complex etiology, diverse causes, prevalence in emerging countries, and minimal financial incentives for the development of pharmaceutical treatments (Guerrant et al., 2002). Regions of the world with the lowest Human Development Index (a measure of citizens' health, education, and living standards) inversely suffer from the highest diarrhea mortality rates (Sergio and Ponce de Leon, 2009). Consequently, WHO, UNICEF, various NGOs and funding agencies are promoting mucosal immunity research, vaccine exploration, and education campaigns for safe water acquisition, oral rehydration therapy (ORT), and effective diarrhea treatments (UNICEF and WHO, 2009).

Instead of treating diarrheal symptoms as natural pathways for ridding the body of disease, a new paradigm in the biomedical field calls for novel ways to treat the causes of infectious diarrhea. By treating the causes — viruses, bacteria, parasites - the severity of disease in patients is reduced, and the infectious agents cannot spread as rampantly 
(Ericsson, 2008; Levine and Svennerholm, 2008). However, with concerns over antibiotic resistance, new ways of reducing the virulence of bacteria without necessarily

killing them (which selects for resistance) is of vital importance, especially in species-rich microenvironments such as the human gut. Plants are common sources of therapies for diarrheal diseases, and analyzing their inhibitory properties against diarrhea-causing bacteria is a promising path toward effective treatments.

\section{PLANT-BASED REMEDIES FOR DIARRHEA}

Plants have been used as medicines by people for millennia. Today, the majority of people in the world use traditional medicines for their primary course of treatment because biomedical healthcare systems and pharmaceuticals are not available in most places. Thus, to improve health and to instill pride in traditional knowledge systems, several governments (e.g., China, India, and South Africa) are incorporating traditional healthcare practices into their national regimes (UNDP, 2010; UN EcoSoC, 2008; WHO, 2003).

\section{Theories that Support Plant-Based Remedies for Diarrhea}

Ethnobotanical theories support the effectiveness of plants for therapeutics, especially when treating gastrointestinal disease. Chemical ecology (Johns, 1990; 1996) and "foods-as-medicines" theories (Etkin, 2000; 2008; Pieroni and Price, 2006) examine the maintenance or restoration of human health through the nutritive and pharmaceutical activities of ingested plants. Foods-as-medicines theories blur the distinction between foods and medicines, as many foods serve therapeutic functions in cultural contexts. Johns (1996) distinguishes foods as substances ingested for energy and nutrients and non- 
foods as plants materials that are ingested as teas, gums, dental brushes, or other nonnutritive supplements. Johns (1996) further argues that the physiological benefits of these non-nutritive plants and human behaviors for their ingestion are not yet fully understood.

Stemming from plant-herbivore studies, chemical ecology places humans in the chemical co-evolution of herbivory, or omnivory. As animals, humans have evolved senses to select appropriate plants for ingestion, digestive enzymes to acquire nutrients from plants, and behaviors or detoxifying enzymes to neutralize harmful plant chemicals (Johns, 1996). On the basis of dietary practices and experimentation, humans have evolved to ingest plants and other matter as preventative and therapeutic aids (Hart, 2005). Johns (1999) postulates that "fundamental forms of medicine involve the gastrointestinal tract" because of the immediate cognitive link between ingesting effective medicinal plants and relief of gastrointestinal ailments. This cognizant association could be one reason why all known pharmacopeias of the world possess remedies for gastrointestinal illness. Another reason is that gastrointestinal ailments are ubiquitous. Therefore, the need for treatments is universal. Like the skin and respiratory tract, the gut is continuously open to potential pathogens and toxins, resulting in the need for therapies as people inevitably fall ill (Balick and Cox, 1997).

\section{Possible Mechanisms of Action for Anti-Diarrheal Plants}

Plant chemicals may relieve diarrhea in numerous ways. Besides providing nutrients and generally increasing gastrointestinal health, plant chemicals can act and bind with a number of different cells in the GI environment, including human epithelial cells, human immune system cells, commensal flora, or pathogenic bacteria. Much plant-based anti-diarrheal research has analyzed the effects of phytochemicals on intestinal tissues 
(e.g., Brijesh, et al., 2006; Grover, et al., 2002; Sagar, et al., 2005; Shaphiullah, et al., 2003; Shilpi, et al., 2006; Teke, et al., 2007). Using rodent models, extracts are evaluated for antispasmodic effects, gut motility suppression, or water and electrolyte reabsorption (e.g., Akindele and Adeyemi, 2006; Mbagwu and Adeyemi, 2008; Sairam, et al., 2003; Thakurta, et al., 2007) with tannins and flavonoids exhibiting promising results for water and electrolyte retention (Palombo, 2006). Astringent and pectin-rich plants often are used to treat diarrheal disease, as are opiates that slow smooth muscle contractions of the intestines (Lewis and Elvin-Lewis, 2003). However, these remedies that suppress intestinal function block the symptoms of diarrhea and not the causes.

Viruses, bacteria, and parasites are the major causes of infectious diarrhea, with bacteria leading to an estimated 2 to 4 billion cases of infectious diarrhea per year and 3 to 5 million deaths (Sanchez and Holmgren, 2005). Phytochemicals inhibit the growth and virulence of diarrhea-causing bacteria in many ways. When bacteria invade the intestines, they follow similar etiologies. The sequence, known as the five stages of pathogenicity (Mitchell, 1998), includes: 1) adherence to host tissue, 2) invasion or control of host tissues, 3) multiplication in host tissues or with nutrients from host tissues, 4) evasion of host defenses, and 5) damage and spread. Phytochemicals can inhibit bacterial growth or virulence at any of these five stages of pathogenicity.

For example, mucilaginous, astringent, and fibrous properties of some plants can mechanically prevent bacterial adhesion to host intestinal cells by direct competition between plant-derived lectins and bacterial membrane glycosides (Coutião Rodriguez, et al., 2001; Rabbani, et al., 2004). Oleanolic acid, ursolic acid, and betulinic acid from ethyl acetate extracts of Chaenomeles speciosa (Sweet) Nakai (Rosaceae) prevent the heat-labile enterotoxin of enterotoxigenic $E$. coli from binding to the appropriate host cell 
receptor, preventing diarrhea in mice (Chen, et al., 2007). As novel bioassays and technological advances are developed, the precise effects and mechanisms of action for plant-based remedies on bacterial pathogenicity is increasingly understood (Brijesh, et al., 2006).

\section{Diarrhea-Definitions and Types}

Diarrhea is defined as an abrupt increase in number of bowel movements to three or more per day, with a concomitant increase in the volume of feces (Wolters, 2010). Some physicians define diarrhea as the passing of $250 \mathrm{~g}$ of stool or more per day (Goljan, 2010). In high-volume diarrhea, fluids are lost as water molecules osmotically follow secreted ions (resulting from bacterial toxins) or excess salts and fats (from foods) into the lumen. The mucosa is not inflamed, so blood and leukocytes do not appear in the feces. Severe secretory diarrhea is often the result of enterotoxins, such as cholera toxin, or an inflammatory response (Wolters, 2010).

When pathogens such as Shigella dysenteriae, Campylobacter jejuni, or Entamoeba histolytica invade the intestinal epithelium, the result is a low-volume diarrhea with blood and leukocytes from the inflamed intestinal epithelium. This is known as dysentery or invasive diarrhea (Goljan, 2010). At the cellular level, intestinal mucosal cells respond to bacterial infection with edema of the superficial layers and inflammation of the lamina propria. As epithelial cells lyse, ulcers form and exude neutrophil-filled fluids. With the loss of goblet cells, mucin production halts and the protective mucus layer passes. Systemically, the results are fever, intestinal cramping, and diarrhea that contains sloughed-off bloody tissues, pus, and mucus. This is the most common result of bacterial infection of gut tissues (Fenoglio-Preiser, et al., 1999). 
Usually, tissues must be damaged or host defenses disrupted before bacteria can adhere to host intestinal tissues and establish infection. Damage might occur during previous infections, especially from viruses, or from bacterial products, such as toxins or enzymes (Jackson, et al. 1998). In the intestines, bacteria must reach epithelial cell surfaces to interact with specific target receptors that trigger cascade responses. Adherence to epithelial cells is more stable than adherence to mucus layers. Plus, adherence to epithelial cells allows for close proximity during toxin release and during nutrient uptake from damaged host cells (Jackson, et al. 1998).

Food poisoning is distinct from gastroenteritis. The former occurs when allocthonous (externally pre-made) toxins are ingested, and it is usually less virulent and of a shorter duration than gastroenteritis (Fenoglio-Preiser, et al., 1999). Food poisoning also causes nausea and vomiting, which are associated with the stomach and esophagus. Gastroenteritis leads to additional diarrhea, which is associated with the intestines. Nonetheless, several bacteria that establish infections in the intestines simultaneously produce toxins to assist in colonization.

When large sections of the intestinal mucosa are damaged, it is essential for the tissue to repair itself quickly. If the barrier function of the mucosa is disrupted, invading pathogens can easily travel throughout the human body and establish infections elsewhere. To keep a semblance of a barrier, the extracellular matrix that lies beneath the epithelial tissues regulates the restitution of the mucosa (Fenoglio-Preiser, et al., 1999). Undamaged epithelia cells form sheets that migrate rapidly over any damaged naked basement membrane, initially ignoring any defects. Once the membrane is restituted, cell proliferation is induced by growth factors. In an otherwise healthy individual, the intestinal epithelium can be completely repaired within a few days. 


\section{RECENT HIGHLIGHTS IN INFECTIOUS DIARRHEA RESEARCH}

Several major discoveries in the past decade have altered research methods in infectious diarrheal diseases and treatments. Four findings relate to the present research and are discussed below. These include 1) the vital role of the human gut flora, or microbiota, in intestinal development and immunity, 2) the diversity and specificity of bacterial secretion and communication systems that lead to colonization and infection of the human gut, 3), the primary immune function of the intestines and connections between inflammation and gastrointestinal health, and 4) the crucial antigen-sampling areas in the intestine, called $\mathrm{M}$ cells, that are targeted by virulent bacteria.

\section{Gut Flora and Illness Prevention}

Research over the past decade has highlighted the complex interactions between human epithelial tissues and both nonpathogenic and virulent bacteria (Granger, 2001; Relman, 2001; Black and Lanata, 2007). Around 400 bacterial species occur in the healthy flora of the small intestine, including Lactobacillus and Streptococcus species and Enterobacteriaceae species (Turnbaugh, et al., 2010). There are more bacteria near the distal (colon) end of the small intestine than the proximal (stomach) end, as there is a decrease in acidity further from the stomach. The colon has an even larger, more diverse population of bacteria than the small intestine (Fenoglio-Preiser, et al., 1999). Normally, one third of feces weight is composed of bacteria (Parker, 2007).

The small intestine controls bacterial growth through the effects of gastric, pancreatic and biliary secretions, as well as copious amounts of mucus, constant motility, and very secure intercellular tight junctions in the apical zona occludens of the columnar epithelium of the villi (Fenoglio-Preiser, et al., 1999). In the large intestine, bacteria 
assist in breaking down fibrous materials and releasing remaining nutrients. Throughout the intestines, bacteria keep the mesenteric immune system in a prepared defensive state by maintaining immune responses, mucus production, and antimicrobial secretions (Clarke and Sperandio, 2005; Stecher and Hardt, 2011).

The normal, commensal flora of the gut wards off virulent bacteria by occupying specialized niches and usurping limited resources. Microenvironments are created by the villi and crypt formations of mucosal tissues, which line the lumen of the small intestine, and by the microvilli on the apical ends of epithelial cells. A dense glycocalyx covers microvilli in the lumen, which is covered by a thick mucus layer and then an unstirred aqueous layer. Hydrogen ions, bicarbonate, mucus, and secretory immunoglobulins are pumped into the unstirred water layer where they interact with bacteria, toxins, and lumen contents (Fenoglio-Preiser, et al., 1999). These layers are barriers between bacteria and intestinal cells, but damaged tissues (from viral infection, toxins) lose the glycocalyx, mucus, and aqueous layers, thereby allowing virulent bacterial to attach and interact with the epithelium.

Phytochemicals alter the microenvironments of the gut. For example, tannic acid chelates iron, preventing iron-seeking bacteria from reaching critical levels of growth (Akiyama, et al., 2001). Polyphenols are capable of altering microenvironments by quenching free radicals, inactivating carcinogens, and stimulating cellular antioxidant defenses while repressing the expression of stress and apoptosis pathways (Vattem and Shetty, 2005). By altering ionic concentrations in the microenvironment, phytochemicals can disrupt communication and signaling pathways between the host and bacteria, thereby preventing or decreasing the severity of infection.

\section{Secretion Systems and Virulence Factors}


The gut is the largest and most complex environment in the human body, and commensal and pathogenic bacteria in the gut are able to communicate with each other and with their host through quorum-sensing (QS) mechanisms (Walters and Sperandio 2006). Through the AI-3/epinephrine/norepinephrine signaling cascade, bacteria use human hormones to respond to available nutrients in their environment and to sense stress pathways and immune responses of the host. Through indole and LuxR homologs, bacteria are able to communicate intercellularly and determine the concentrations of related or unrelated species in the environment (Nostro, 2006). If a quota of related species is reached, signal-cascade responses are induced, often leading to the upregulation of genes that encode virulence factors for motility, adherence, toxins, or secretion systems. In essence, the bacteria become pathogenic (Rendón, et al, 2007).

During the past decade, bacterial virulence factors and their delivery systems have been the focus of intense research (Anderson, 2006). Currently, six secretion systems and twin-arginine translocation proteins have been described in Gram negative bacteria, while the secretory ( $\mathrm{Sec}$ ) pathway has been examined in Gram positive bacteria. Several of the worst bacteria to cause gastrointestinal disease (E. coli, Shigella, Salmonella, and Yersinia spp.) utilize a Type III Secretion System (T3SS) to insert virulence factors directly into host epithelial cells (Deane, et al., 2006; Hueck, 1998; Stuber, et al., 2003). Pseudomonas spp. and other plant pathogens utilize the T3SS and virulence factors similar to human pathogenic bacteria (Deslandes, et al. 2003; Hauck, et al. 2003). Generally, virulence factors are genes for production of bacterial proteins, toxins that disrupt host cellular activities, or protein signals that subvert normal host cell activities (Arbeloa, et al., 2011; Dean, et al., 2006). Some injected virulence factors manipulate the host cytoskeleton to surround the bacterial cell in a protective manner, 
preventing detection of the bacteria by host immune defenses (García-del Portillo, et al., 2008). Other virulence factors, such as those in enteropathogenic E. coli, Salmonella, Helicobacter pylori, Staphylococcus, and Clostridium difficile, interact with the host mitochondria (Kozjak-Pavlovic, et al., 2008), thereby altering cellular metabolism in host tissues.

Further elucidation of these and other host-pathogen interactions could bring about effective points in the virulence and infection process where phytochemicals or other compounds could disrupt inter-bacterial communication, quorum sensing, virulence triggering, or secretion system construction and prohibit pathogenicity in gut bacteria (Nostro, 2006). More importantly, disrupting the pathogenicity of bacteria without killing them can prevent selection for resistant strains (Adonizio, et al. 2006).

\section{Inflammation and Mucosal Immunity}

The GI tract is the interface between the internal body and the external world. As such, it is continuously exposed to pathogens and dangerous chemicals and plays a critical role in generating and maintaining mucosal immunity (Cerf-Bensussan and GaboriauRouthiau, 2010). More than any other area of the body, the small intestine produces the most antibodies and contains the most lymphoid cells, resulting in impressive immunological activity (Fenoglio-Preiser, et al., 1999). In the lamina propria of the mucosa, besides the usual connective tissues, blood vessels, nerves, muscles, lacteals, and lymph ducts, there are numerous immunoglobulin-containing plasma cells. Most contain Ig-A, but Ig-M, D, G, and E are also present. Within the villi of the mucosa, macrophages aggregate at the tips and send pseudopods into the epithelial lining to absorb apoptotic cells and monitor for invasion (Fenoglio-Preiser, et al., 1999). 
The digestive system plays a critical role in immune response, but also, it is quickly converted to a site of inflammation in response to ingested chemicals, microbes, and allergens. Chronic gastrointestinal diseases such as Guillain-Barré Syndrome are associated with previous Campylobacter jejuni infections (Vucic, et al. 2009), and bacterial overgrowth of the intestines and deconjugation of bile acids can lead to chronic inflammatory diarrhea (Binder, 2009). Research now shows that bacteria such as E. coli are able to induce inflammatory responses through toxins (Jackson, et al., 1998), or read hormonal changes in already inflamed tissues (Sperandio, et al., 2003), which trigger bacterial virulence factors and gut colonization. Other related bacteria most likely carry out similar responses. Anti-inflammatory and anti-oxidant phytochemicals can reduce the inflammation associated with bacterial infections and prevent secondary disease of the GI tract.

\section{Cells as Targets for Bacterial Invasion}

With technological advances in physiology, specific cells in the intestines have been found to play a large role in human immunity and bacterial infection (Neutra, 1998). In Peyer's patches of the ileum, unique M cells reside in the central dome of the follicle. The M cells have fewer, shorter microvilli called microfolds and less glycocalyx than their surrounding enterocyte neighbors, to which they do not form tight junctions (Owen, 1999). The M cells create thin apical "cytoplasmic rims" that are full of endocytic vesicles. Abundant glycoconjugates are available on the surface of $\mathrm{M}$ cells for cationic molecules or lectin-like microbial surface binding (Fenoglio-Preiser, et al., 1999). The one-cell thick cytoplasmic rim of the $\mathrm{M}$ cell is all that stands between the lumen contents and lymphocytes. Antigens from the lumen are directly carried over to lymphoid tissues 
where they can induce immune responses that can quickly reach systemic proportions, if necessary (Jang, et al., 2004).

Although M cells are a quick, efficient way for antigen processing to occur, they are also the preferred route of entry for some pathogenic microbes. Listeria, Vibrio, Salmonella, Shigella, and rotoviruses all use M cells to invade the epithelium of the colon (Corr, et al., 2008). Yersinia enterocolitica and E. coli strains that express invasin, a virulence factor that binds to host cell integrins, actively seek out and select $\mathrm{M}$ cells for invasion (Jang, et al., 2004). Discovering that $\mathrm{M}$ cells are sites for specific receptors and trans-cytosis is imperative for developing ways to prevent and treat intestinal bacterial infection.

\section{Combining Intestinal Immunity and Bacterial Virulence Studies in Anti-Diarrheal \\ Plant Research}

A combination of techniques that utilize intestinal immunity factors and bacterial virulence factors should lead to more refined bioassays and evaluation procedures for analyzing plant-based remedies. For example, when E. coli or Yersinia strains express the virulence factor invasin which allows them to seek out $\mathrm{M}$ cells in the intestines, plant compounds might be able to disrupt infection by competing for binding sites with invasin or altering the $\mathrm{pH}$ of the microenvironment and slightly but significantly denaturing the signaling protein for invasin production. Phytochemicals can inhibit pathogenicity of bacteria at several points along the five stages of pathogenicity.

\section{ANTI-DIARRHEAL PLANTS OF CENTRAL ANATOLIA, TURKEY}


During the past 40 years, ethnopharmacologists have been gathering information about medicinal plants in various regions of Turkey. Villagers have related a rich botanical knowledge that varies with the landscape. However, new social reforms in Turkey have made medicines and healthcare relatively accessible and virtually free to all Turkish citizens. As a result, Turkish knowledge systems involving diarrhea and how to treat it are in a state of flux (Yeşilada, et al., 1999). Government hospitals and the World Health Organization (WHO) campaigned amongst Turkish villages to promote the use of hospitals and clinics in cases of childhood diarrhea as opposed to traditional treatments. With educational campaigns for oral-rehydration therapy (ORT) and improved awareness in clean food preparation, childhood cases of diarrhea dropped from more than 710,000 children in 1996 to 188,000 in 2000 (The Ministry of Health of Turkey, 2004).

Decreasing numbers in diarrheal morbidity and mortality are a welcomed accomplishment, and responsible organizations and individuals deserve applause. However, changes in health care practices at the level of the individual most likely lead to changes in the use of home remedies, such as plant-based remedies. Analyzing changes in knowledge of diarrheal disease and anti-diarrheal plants at the local level could lead to a better understanding of how people are relating to their health, their national healthcare system, and the plants in their environments.

\section{Diarrheal Disease in Turkey}

Neither precise estimates nor information pertaining to leading causes of diarrhea in Turkey are available. First, most cases of diarrhea are treated at home and are not reported to hospitals. Second, when a patient arrives at a hospital, the first concern is to treat dehydration and other diarrheal symptoms. Treatment of symptoms does not require 
knowing the cause. Third, many hospitals or clinics are not equipped to culture and identify pathogenic microbes. Fourth, no mechanism is in place to track or analyze data.

Global reports from the WHO (UNICEF and WHO 2009; Kosek, et al., 2003), the CDC (2008), and other sources (Guerrant, et al., 2002; Zhang, 2008) identify the major causative agents for diarrhea in rural areas on a global scale to be Campylobacter, Shigella, Salmonella, E. coli, Vibrio, Yersinia, Listeria, Staphylococcus, Clostridium, and Klebsiella. The most prevalent cases of diarrhea that result from food poisioning are caused by Salmonella enterica. However, the prevalence of Campylobacter is increasing, as are cases of enterohemorrhagic E.coli (EHEC). Apart from food poisoning, infective colitis often results from Yersinia enterocolitica, Campylobacter jejuni, and Shigella dysenteriae. Klebsiella, Pseudomonas, and Chlamydia are probably the most common causes of chronic colitis (Fenoglio-Preiser, et al., 1999).

Diarrheal disease etiologies in children under the age of five have been examined in hospitals in neighboring Bulgaria (Nedkova, et al., 2008). Preliminary results showed that $60 \%$ of pediatric diarrhea patients in hospitals had an identifiable pathogen present in stool samples, some with both viruses and bacteria. Bacterial strains were identified in $20 \%$ of the samples, with strains of Salmonella, E. coli, Shigella, Campylobacter, and Yersinia enterocolitica present in order from most to least.

More distant geographically, a study in diarrheal etiologies in children in Egypt (El-Mohamady, et al., 2006) identified causative agents in $46 \%$ of children sampled, with $17 \%$ of all children suffering from rotavirus, $20.7 \%$ of children infected with bacteria, $10.7 \%$ had Cryptosporidium, a Nile parasite, and $6.1 \%$ had a combination of causative agents. Bacteria included enterotoxigenic E. coli (10.8\%), Campylobacter jejuni or $C$. 
coli (5.6\%), Shigella flexneri, S. dysenteriae, or S.boydii (2\%), Aeromonas hydrophila (1.1\%), Salmonella (0.6\%), and Vibrio fluvialis $(0.6 \%)$.

Overall, the most likely bacterial causes of diarrheal disease in Turkey are pathogenic E. coli strains, Salmonella, Shigella, Campylobacter, Staphylococcus, Yersinia, and possibly Vibrio, Listeria, Aeromonas, and Klebsiella.

\section{The Phytogeography of Turkey}

Turkey straddles Europe and Asia, with Africa just across the Mediterranean. Three large ecosystems converge here (Davis, 1965). Sclerophyllous Mediterranean forests cover western mountains in Turkey. In the south, the Syrian-Iraqi desert influences coniferous and deciduous montane forests. To the northeast, the Russo-Iranian mountains are covered in deciduous (at times euxine-colchic) forests (Olson, et al., 2001). At the center of these varied mountain forests, a central plateau, described as semiarid steppe (BSk type in Peel, et al., 2007), gradually inclines in elevation from sea level in the west to 1700 meters in the east.

The plateau has cold, wet winters and dry, hot summers. Annual precipitation averages $400 \mathrm{~mm}$ in the central plateau and southeast desert borderlands, but along the coasts of Turkey, precipitation doubles (Ergener, 2002). Turkey is a temperate nation with rich biodiversity. Of the estimated 9,000 to 10,000 species of vascular plants in Turkey, a third of the species are endemic (Kaya and Raynal, 2001). More than 400 new Turkish plant species have been described in the past 30 years (Güner et al., 2001), illustrating the need for further research in Turkish botany and pharmacognosy. 


\section{Anti-diarrheal Plants of Turkey}

Many Turkish medicinal plant species, including anti-diarrheal plants, have been recorded in the past few decades (Ertuğ, 2000; Fujita, et al., 1995; Honda, et al., 1996; Özgökçe and Özçelik, 2004; Sezik, et al., 1991; Sezik, et al., 1992; Sezik, et al., 1997; Sezik, et al., 2001; Tabata, et al., 1994; Tuzlac1 and Aymaz, 2001; Tuzlac1 and Tolon, 2000; Yeşilada, et al., 1993; Yeşilada, et al., 1995; Yeşilada, et al., 1999). Consistent between reports, plants for gastrointestinal ailments comprise about a third of most regional pharmacopeias in Turkey, including Central Anatolia. Anti-diarrheal plants often belong to the well-represented Lamiaceae, Rosaceae, and Asteraceae, which are congruent with the semiarid steppe climate of Central Anatolia. Species in Lamiaceae comprise $22 \%$ of gastrointestinal remedies recorded in all of Turkey, while species in Rosaceae compose 12\%, and those in Asteraceae compose 10\% (personal data, Chapter II). Previous investigation (summarized in Duke, 1997; Lewis and Elvin-Lewis, 2003) of the medicinal use of these families records anti-oxidant and anesthetic properties in essential oils of Lamiaceae, soothing pectin and astringent tannins in Rosaceae, and antiinflammatory sesquiterpenes in Asteraceae. However, how these plants might inhibit pathogenic bacteria in the gut is still to be determined.

\section{DISSERTATION RESEARCH}

Many studies on the effectiveness of anti-diarrheal plants have examined the effects of plant chemicals on gastrointestinal tissues in mouse or rat models (see Palombo 2006 for a review) or on standard E. coli and Staphylococcus aureus strains of bacteria (Cowan, 1999). Until the present study, little has been done to screen anti-diarrheal plants for inhibitory properties against diarrhea-causing bacteria such as Shigella, 
Yersinia, Enterococcus, Klebsiella, Listeria, Vibrio, or Salmonella species. In the current study, bioassays using a wide range of diarrhea-causing bacteria were performed to evaluate the antibacterial properties of fifteen anti-diarrheal plants from Central Anatolia, Turkey.

From September 2008 to September 2009, I conducted ethnobotanical research in Central Anatolia with the following four objectives: The first was to determine the specific folk concepts, classifications, and etiologies of diarrheal diseases perceived by Turkish villagers of Central Anatolia and to identify botanical treatments that villagers used. I wanted to understand why villagers used the plants that they did and whether the present use of plants differed from plants reported in previous Turkish ethnobotanical studies. The second objective was to analyze the botanical remedies for bactericidal and bacteriostatic properties, especially in relation to infectious bacteria that cause diarrhea. The third aim was to evaluate the safety of plant-based remedies for human consumption. Plants commonly consumed as foods, spices, or medicines often are assumed to be safe, but cytotoxicity screenings can test dose-dependent toxicity and cellular responses to phytochemicals. Following the first three objectives of the research, my final aim was to isolate and identify the bioactive compound(s) from the extract that inhibited the most bacteria at the lowest concentrations with little human cytotoxicity.

Two hypotheses were formulated to address the first objective of understanding folk concepts of diarrheal disease and its treatment. H1a. Rural inhabitants of Central Anatolia treat diarrhea with plant-based remedies, and H1b. The anti-diarrheal pharmacopeia changes over time. To evaluate the antibacterial properties of the individual botanical treatments, two more hypotheses were devised. H2a. Each Central Anatolian anti-diarrheal plant is bacteriostatic against each bacterial strain. H2b. Each 
Central Anatolian anti-diarrheal plant is bactericidal against each bacterial strain. For the third objective involving cytotoxicity, I hypothesized: H3. Each Central Anatolian antidiarrheal plant shows no toxicity to the cell lines used in the Alamar Blue Cytotoxicity Assay. Finally, I hypothesized: H4. The combined inhibitory and toxicity data support the traditional use of Central Anatolian anti-diarrheal plants.

In chapter II, I address the first objective of my research. As biomedical definitions of diarrhea may differ from the conceptualizations of Turkish villagers, I employed free-listing techniques and saliency rankings to assess disease concepts, causes, and classifications, and I conducted an ethnobotanical survey to determine botanical remedies. The third chapter describes laboratory work conducted in Turkey with collaborators at my sponsoring institution, Gazi University. Bactericidal and bacteriostatic properties of 34 extracts from 15 Turkish plants used to treat diarrhea were determined in assays that included ten strains of diarrhea-causing bacteria. The fourth chapter describes a second antibacterial assay with a panel of twenty-one bacterial strains conducted at Florida International University and a cytotoxicity assay utilizing Alamar Blue to determine the cytotoxicity of the fifteen plants under investigation. The laboratory analysis led to the further investigation of one plant part, the galls from Rosa canina L. (Rosaceae), as it inhibited the most bacteria at the lowest minimum inhibitory concentrations (MICs). The fifth chapter details the bioassay-guided fractionation of the methanolic extract from $R$. canina galls and the resulting chemical identification of ellagic acid as the chemical responsible for bacterial inhibition.

\section{REFERENCES}

Adonizio A, Downum K, Bennett B, Mathee K. 2006. Anti-quorum sensing activity of medicinal plants in southern Florida. J Ethnopharmacol 105: 427-435. 
Akindele AJ, Adeyemi OO. 2006. Evaluation of the antidiarrhoeal activity of Byrsocarpus coccineus. J Ethnopharmacol 108: 20-25.

Akiyama H, Fujii K, Yamasaki O, Oono T, Iwatsuki K. 2001. Antibacterial action of several tannins against Staphylococcus aureus. Journal of Antimicrobial Chemotherapy 48: 487-491.

Anderson LL. 2006. Discovery of the 'porosome'; the universal secretory machinery in cells. Journal of Cellular and Molecular Medicine 10: 126-31.

Arbeloa A, Oates C, Marchés O, Hartland E, Frankel G. 2011. Enteropathogenic and enterohemorrhagic Escherichia coli type III secretion effector EspV induces radical morphological changes in eukaryotic cells. Infection and Immunity March: 1067-1076.

Balick M, Cox P. 1997. Plants, People, and Culture: The Science of Ethnobotany. Scientific American Library: New York.

Binder H. 2009. Mechanisms of diarrhea in inflammatory bowel diseases. Ann NY Acad Sci 1165: 285-293.

Black R, Lanata C. 2007. Diarrheal Diseases. In Infectious Disease Epidemiology: Theory and Practice, Nelson EK, Williams CF (eds). Jones and Bartlett: Sudbury, MA; 759-786.

Brijesh S, Daswani PG, Tetali P, Rokatkar SR, Birdi T J. 2006. Studies on Pongamia pinnata (L) Pierre leaves: understanding the mechanism(s) of action in infectious diarrhea. J. Zhejiang University Sci Bull 7: 665-674.

CDC, Centers for Disease Control and Prevention. 2008. Preliminary Foodborne Diseases Active Surveillance Network (FoodNet) Data. Morbidity and Mortality Weekly Report: (http://www.cdc.gov/epo/mmwr/preview/mmwrhtml/mm4910a1 .htm).

Cerf-Bensussan N, Gaboriau-Routhiau V. 2010. The immune system and the gut microbiota: friends or foes? Nature Reviews Immunology 10: 735-744.

Chen JC, Chang YS, Wu SL, Chao DC, Chang CS, Li CC, et al. 2007. Inhibition of Escherichia coli heat-labile enterotoxin-induced diarrhea by Chaenomeles speciosa. $J$ Ethnopharmacol 113: 233-239.

Clarke M, Sperandio V. 2005. Events at the host-microbial interface of the gastrointestinal tract III. Cell-to-cell signaling among microbial flora, host, and pathogens: there is a whole lot of talking going on. Amer J Physio: Gastrointestinal and Liver Physio 288: 1105-1109.

Corr S, Gahan CC, Hill C. 2008. M-cells: origin, morphology and role in mucosal immunity and microbial pathogenesis. F E M S Immuno Med Microbio 52: 2-12. 
Coutião Rodriguez R, Hernandez-Cruz P, Giles-Rãos H. 2001. Lectins in fruits having gastrointestinal activity: their participation in the hemagglutinating property of Escherichia coli O157:H7. Arch Med Res 32: 251-7.

Cowan MM. 1999. Plant products as antimicrobial agents. Clin Microbiol Rev 12: 564 582.

Davis PH. 1965. Flora of Turkey and the East Aegean Islands (Vol. 1). Edinburgh University Press: Edinburgh.

Dean P, Maresca M, Schüller S, Phillips A, Kenny B. 2006. Potent diarrheagenic mechanism mediated by the cooperative action of three enteropathogenic Escherichia coli-injected effector proteins. PNAS 103: 1876-1881.

Deane J, Roversi P, Cordes F, Johnson S, Kenjale R, Daniell S, et al. 2006. Molecular model of a type III secretion system needle: Implications for host-cell sensing. PNAS 103: 12529-12533.

Deslandes L, Olivier J, Peeters N, Feng DX, Khounlotham M, Boucher C, Somssich I, Genin S, Marco Y. 2003. Physical interaction between RRS1-R, a protein conferring resistance to bacterial wilt, and PopP2, a type III effector targeted to the plant nucleus. PNAS 100: 8024-8029.

Duke J. 1997. The Green Pharmacy: New Discoveries in Herbal Remedies for Common Disease and Conditions from the World's Foremost Authority on Healing Herbs. Rodale: New York.

El-Mohamady H, Abdel-Messih I, Youssef F, Said M, Farag H, Shaheen H, et al. 2006. Enteric pathogens associated with diarrhea in children in Fayoum, Egypt. Diagnostic Microbio Infec Dis 56: 1-5.

Ergener R. 2002. About Turkey: Geography, Economy, Politics, Religion, and Culture. Pilgrims' Process, Inc.: Boulder, CO.

Ericsson C. 2008. Traveler's Diarrhea. BC Desk, Inc.: Hamilton, Ontario.

Ertuğ F. 2000. An ethnobotanical study in Central Anatolia (Turkey). Econ Bot 54: 155182.

Etkin N. 2000. Eating on the Wild Side: The Pharmacologic, Ecologic, and Social Implications of Using Noncultigens. University of Arizona Press: Tucson.

Etkin N. 2008. Edible Medicines: An Ethnopharmacology of Food. University of Arizona Press: Tucson.

Fenoglio-Preiser CM, Noffsinger AE, Stemmermann GN, Lantz P, Listrom M, Rilke F. 1999. Gastrointestinal Pathology: An Atlas and Text (2nd edn). Lippincott-Raven Publishers: Philadelphia. 
Fujita T, Sezik E, Tabata M, Yeşilada E, Honda G, Takeda Y, et al. 1995. Traditional medicine in Turkey VII. Folk medicine in middle and west Black Sea Regions. Econ Bot 49: 406-422.

García-del Portillo F, Núñez-Hernández C, Eisman B, Ramos-Vivas J. 2008. Growth control in the Salmonella-containing vacuole. Curr Opinion Microbio 11: 46-52.

Goljan E. 2010. Rapid Review Pathology (3rd edn). Mosby Elsevier: Philadelphia.

Granger D. 2001. Basic Principles of Host Defense. In Current Diagnosis and Treatment in Infectious Diseases, Wilson W, Sande M (eds). McGraw Hill: New York; 3-19.

Grover JK, Khandar S, Vats V, Dhunnoo Y, Das D. 2002. Pharmacological studies on Myristica fragrans - antidiarrheal, hypnotic, analgesic and hemodynamic (blood pressure) parameters. Meth Find Exper Clin Pharmaco 10: 675-80.

Guerrant RL, Kosek M, Moore S, Lorntz B, Brantley R, Lima AA. 2002. Magnitude and Impact of Diarrheal Diseases. Arch Med Res 33: 351-5.

Güner A, Ozhatay N, Ekim T, Baser KH, Hedge I. 2001. Flora of Turkey and the East Aegean Islands (Vol. 11). Edinburgh University Press: Edinburgh.

Hart B. 2005. The evolution of herbal medicine: behavioural perspectives. An Beh 70: 975-989.

Hauck P, Thilmony R, He SY. 2003. A Pseudomonas syringae type III effector suppresses cell wall-based extracellular defense in susceptible Arabidopsis plants. PNAS 100: $8577-8582$.

Honda G, Yeşilada E, Tabata M, Sezik E, Fujita T, Takeda Y, et al. 1996. Traditional medicine in Turkey VI. Folk medicine in West Anatolia: Afyon, Kütahya, Denizli, Muğla, Aydın Provinces. J Ethnopharmacol 53: 75-87.

Hueck CJ. 1998. Type III protein secretion systems in bacterial pathogens of animals and plants. Microbio Molec Bio Rev 62: 379-433.

Jackson A, Dowling R, Wilson R. 1998. Interaction of bacteria and their products with tissues in organ culture. In Methods in Microbiology: Bacterial Pathogenesis, Williams P, Ketley J, Salmond G (eds). Academic Press: San Diego; 73-82.

Jang MH, Kweon MN, Iwatani K, Yamamoto M, Terahara K, Sasakawa C, et al. 2004. Intestinal Villous M cells: An antigen entry site in the mucosal epithelium. PNAS

101: 6110-6115. 
Johns T. 1999. The chemical ecology of human ingestive behaviors. Ann Rev Anthro 28: 27-50.

Johns T. 1996. The Origins of Human Diet and Medicine: Chemical Ecology. University of Arizona Press: Tucson.

Johns T. 1990. With Bitter Herbs They Shall Eat It. University of Arizona Press: Tucson.

Kaya Z, Raynal J. 2001. Biodiversity and conservation of Turkish forests. Biol Conserv 97: 131-141.

Kosek M, Bern C, Guerrant RL. 2003. The Global Burden of Diarrhoeal Disease, as estimated from studies published between 1992 and 2000. Bull WHO 81: 197-204.

Kozjak-Pavlovic V, Ross K, Rudel T. 2008. Import of bacterial pathogenicity factors into mitochondria. Curr Opin Microbio 11: 9-14.

Levine M, Svennerholm AM. 2008. Immunoprophylaxis and immunologic control. In Traveler's Diarrhea, Ericsson C (ed). BC Deck, Inc.: Hamilton, Ontario; 215-232.

Lewis W, Elvin-Lewis M. 2003. Medical Botany: Plants Affecting Human Health. John Wiley Interscience: New York.

Marcos L, DuPont H. 2007. Advances in defining etiology and new therapeutic approaches in acute diarrhea. J Infection 55: 385-383.

Mbagwu HO, Adeyemi OO. 2008. Anti-diarrhoeal activity of the aqueous extract of Mezoneuron benthamianum Baill (Caesalpiniaceae). J Ethnopharmacol 116: 16-20.

Mitchell T. 1998. Introduction: Host Interactions--Animals. In Methods in Microbiology: Bacterial Pathogenesis (Vol. 27), Williams P, Ketley J, Salmond G (eds). Academic Press: San Diego; 69-72.

Nedkova V, Komitova R, Popova V, Hitkova H, Mladenova Z, Korsun N, et al. 2008. Diarrheal etiology in children under five in Bulgaria - A prospective study - Preliminary results. 13th International Congress on Infectious Diseases Abstracts, Poster Presentations e80.

Neutra M. 1998. Current Concepts in Mucosal Immunity V. Role of M cells in transepithelial transport of antigens and pathogens to the mucosal immune system. Amer $J$ Physio: Gastrointestinal and Liver Physio 274: G785-G791. 
Nostro A. 2006. Activity of plant extracts and plant-derived compounds against drugresistant microorganisms. In Modern Phytomedicine: Turning Medicinal Plants into Drugs, Ahmad I, Aqil F, Owais M (eds). Wiley-VCH Verlag GmbH \& Co. KGaA: Weinham; 199-226.

Olson D, Dinerstein E, Wikramanaya E, Burgess N, Powell G, Underwood E, et al. 2001. Terrestrial ecoregions of the world: A new map of life on Earth. BioSci 51: 933-938.

Owen R. 1999. Uptake and transport of intestinal macromolecules and microorganisms by $\mathrm{M}$ cells in Peyer's patches - a personal and historical perspective. Immuno 11: 157-163.

Özgökçe F, Özçelik H. 2004. Ethnobotanical aspects of some taxa in East Anatolia, Turkey. Econ Bot 58: 697-704.

Palombo E. 2006. Phytochemicals from traditional medicinal plants used in the treatment of diarrhoea: Modes of action and effects on intestinal function. Phytother Res 20: 717 724.

Parker S. 2007. The Human Body Book. Dorling Kindersley, Ltd.: London New York.

Peel MC, Finlayson BL, McMahon TA. 2007. Updated world map of the Köppen-Geiger climate classification. Hydro Earth Sys Sci 11: 1633-1644.

Pieroni A, Price LL. 2006. Eating and Healing: Traditional Food as Medicine. The CRC Press: Boca Raton, FL.

Rabbani GH, Teka T, Saha SK, Zaman B, Majid N, Khatun M, et al. 2004. Green banana and pectin improve small intestinal permeability and reduce fluid loss in Bangladeshi children with persistent diarrhea. Digestive Disorders Sci 49: 475-484.

Relman D. 2001. Basic Principles of Microbial Virulence. In Current Diagnosis and Treatment in Infectious Diseases, Wilson MS (ed). McGraw Hill: New York; 20-27.

Rendón M, Saldaña Z, Erdem A, Monteiro-Neto V, Vázquez A, Kaper JB, et al. 2007. Commensal and pathogenic Escherichia coli use a common pilus adherence factor for epithelial cell colonization. PNAS 104: 10637-10642.

Sagar L, Sehgal R, Ojha S. 2005. Evaluation of antimotility effect of Lantana camara L. var. acuelata constituents on neostigmine induced gastrointestinal transit in mice. BMC Complementary and Alternative Medicines 175: 18. 
Sairam K, Hemalatha S, Kumar A, Srinivasan T, Ganesh J, et al. 2003. Evaluation of antidiarrhoeal activity in seed extracts of Mangifera indica. J Ethnopharmacol 84: 11-15.

Sanchez J, Holmgren J. 2005. Virulence factors, pathogenesis and vaccine protection in cholera and ETEC diarrhea. Curr Opin Immuno 17: 388-398.

Sergio JV, Ponce de Leon AC. 2009. Analysis of mortality from diarrheic diseases in under-five children in Brazilian cities with more than 150,000 residents. Cad. Saúde Pública 25: 1093-1102.

Sezik E, Tabata M, Yeşilada E, Honda G, Goto K, Ikeshiro Y. 1991. Traditional medicine in Turkey I. Folk medicine in North-east Anatolia. J Ethnopharmacol 35: 191-196.

Sezik E, Yeşilada E, Honda G, Takaishi Y, Takeda Y, Tanaka T. 2001. Traditional medicine in Turkey X. Folk medicine in Central Anatolia. J Ethnopharmacol 75: 95-115.

Sezik E, Yeşilada E, Tabata M, Honda G, Takaishi Y, Fujita T, et al. 1997. Traditional medicine in Turkey VIII. Folk medicine east Anatolia. Econ Bot 51: 195-211.

Sezik E, Zor M, Yeşilada E. 1992. Traditional medicine in Turkey II. Folk medicine in Kastamonu. Int J Pharmacognosy 30: 233-239.

Shaphiullah M, Bachar SC, Kundu JK, Begum F, Uddin MA, Roy SC, et al. 2003. Antidiarrheal activity of the methanol extract of Ludwigia hyssopifolia L. Pakistan J Pharmaceut Scie 16: 7-11.

Shilpi JA, Taufiq-Ur-Rahman M, Uddin SJ, Alam MS, Sadhu SK, Seidel V. 2006. Preliminary pharmacological screening of Bixa orellana L. leaves. J Ethnopharmacol 108: $264-271$.

Sperandio V, Torres A, Jarvis B, Nataro J, Kaper J. 2003. Bacteria-host communication: The language of hormones. PNAS 100: 8951-8956.

Stecher B, Hardt WD. 2011. Mechanisms controlling pathogen colonization of the gut. Curr Opin Microbio 14: 82-91.

Stuber K, Frey J, Burnens AP, Kuhnert P. 2003. Detection of type III secretion genes as a general indicator of bacterial virulence. Molec Cell Probes 17: 25-32.

Tabata M, Sezik E, Honda G, Yeşilada E, Goto K, Ikeshiro Y. 1994. Traditional medicine in Turkey III. Folk medicine in east Anatolia; Van and Bitlis Provinces. Int J Pharmacognosy 32: 3-12. 
Teke GN, Kuiate JR, Ngouateu OB, Gatsing AD. 2007. Antidiarrhoeal and antimicrobial activities of Emilia coccinea (Sims) G. Don extracts. J Ethnopharmacol 112: 278-283.

Thakurta P, Bhowmik P, Mukherjee S, Hajra T, Patra A, Bag P. 2007. Antibacterial, antisecretory and antihemorrhagic activity of Azadirachta indica used to treat cholera and diarrhea in India. J Ethnopharmacol 111: 607-612.

The Ministry of Health of Turkey. 2004. Turkey Health Report. The Ministry of Health of Turkey: Ankara.

Turnbaugh PJ, Quince C, Faith JJ, McHardy AC, Yatsunenko T, Niazi F, et al. 2010. Organismal, genetic, and transcriptional variation in the deeply sequenced gut microbiomes of identical twins. PNAS 107: 7503-7508.

Tuzlacı E, Aymaz P. 2001. Turkish folk medicinal plants, Part IV: Gönen (Balıkesir). Fitoter 72: 323-343.

Tuzlacı E, Tolon E. 2000. Turkish folk medicinal plants, part III: Sile (Istanbul). Fitoter 71: 673-685.

UN EcoSoC. 2008. The contribution of traditional medicine to the realization of international development objectives related to global public health. United Nations Economic and Social Council: 1-3. http://esango.un.org/event/documents/Draft\%20$\% 20$ Issues\%20note.Traditional\%20Medicine1.pdf

UNDP. 2010. Medicinal Plants: Traditional Formulae to Health Security. 2010 Human Development Report http://www.undp.org.in/conservation_medicinal_plants.

UNICEF and WHO. 2009. Diarrhoea: Why children are still dying and what can be done. World Health Organization: Geneva. http://whqlibdoc.who.int/publications /2009/9789241598415_eng.pdf

Vattem DA, Shetty K. 2005. Biological funcionality of ellagic acid: A review. J Food Biochem 29: 234-266.

Vucic S, Kiernan MC, Cornblath DR. 2009. Guillain-Barré syndrome: an update. J Clin Neurosci 16:733-41.

Walters M, Sperandio B. 2006. Quorum sensing in Escherichia coli and Salmonella. Int J Med Microbiol 296: 125-131.

WHO and UNICEF. 2004. Clinical Management of Acute Diarrhoea. World Health Organization and United Nations' Children's Fund: Geneva. http://www.who.int/ 
child_adolescent_health/documents/who_fch_cah_04_7/en/index.html

WHO. 2003. Traditional Medicine. Fifty-Sixth World Health Assembly A56/18 March 31: 1-4. (http://www.who.int/gb/eb_wha/pdf/wha56/ea5618.pdf.)

Wolters KH. 2010. Professional Guide to Pathophysiology (3rd edn). Lippincott, Williams \& Wilkins: Philadelphia.

Yeşilada E, Honda G, Sezik E, Tabata M, Fujita T, Tanaka T, et al. 1995. Traditional medicine in Turkey V. Folk medicine in the Inner Taurus Mountains. $J$ Ethnopharmacol 46:133-152.

Yeşilada E, Honda G, Sezik E, Tabata M, Goto K, Ikeshiro Y. 1993. Traditional medicine in Turkey IV. Folk medicine in the Mediterranean subdivision. J Ethnopharmacol 39: 3138 .

Yeşilada E, Sezik E, Honda G, Takaishi Y, Takeda Y, Tanaka T. 1999. Traditional medicine in Turkey IX: Folk medicine in north-west Anatolia. J Ethnopharmacol 64: 195-210.

Zhang Y. 2008. Encyclopedia of Global Health. SAGE Publications: Los Angeles, CA. 


\title{
Chapter II
}

\section{DISEASE CONCEPTS AND ETHNOBOTANY OF DIARRHEAL DISEASES IN CENTRAL ANATOLIA}

\begin{abstract}
Acute gastrointestinal illness is a common, life-threatening complication for rural villagers in developing countries such as Turkey. My study identifies and describes the classification schemes surrounding acute gastrointestinal illness and its folk etiologies and treatments among Central Anatolian villagers. I conducted informal small group interviews with rural Turkish villagers in the spring of 2009 and used scenarios, recall, free-listing, and ranked saliency techniques to determine the shared knowledge that residents held about diarrheal disease. The perceived causes of illness included germ theory, food preparation, evil eye, hot/cold values, and other folk theories. Common treatments included foods immediately available in the home as well as plants collected nearby. Central Anatolian villagers had a malleable, shifting understanding of gastrointestinal disease, influenced by recent biomedical education campaigns along with traditional village beliefs and practices. These findings are evidence of a culture dealing with change at local, national, and global levels.
\end{abstract}

Keywords: Ranked Saliency, Acute Gastrointestinal Illness, Diarrhea, Traditional Health, Turkey, Central Anatolia 


\section{INTRODUCTION}

Diarrheal disease in Turkey, as in most parts of the world, is ever-present and, at times, life-threatening. Worldwide, complications from diarrhea such as dehydration and malnutrition lead to the deaths of an estimated 2 to 5 million people annually, with 1.8 million being children under the age of five (WHO and UNICEF 2004). Morbidity affects even more children, as each child averages 3.3 episodes of diarrhea per year. In Turkey, $10 \%$ of infant mortality is caused by diarrhea (Ergener 2002), and uncounted others fall ill yet recover.

Episodes of diarrhea in children lead to vicious cycles of malnutrition, stunted development, and susceptibility to other pathogens (Simeon and Grantham-McGregor 1990). In some regions of Turkey, the Ministry of Health provides medicines, iron supplements, and nutritious foods in school lunches to combat malnutrition and helminthic diarrhea (PCD 2000). Diarrhea and its effects decrease performance measures in students (Ulukanlığgl and Seyrek 2004), which is a national concern.

Around the world, researchers have surveyed plant-based remedies for gastrointestinal disease (e.g., Mexico-Berlin and Berlin 1996; Heinrich, Rimpler, and Barrera 1992, India—-Tetali et al. 2009, Nigeria —Agunua et al. 2005, and South AfricaFawole et al. 2009; Mathabe et al. 2006). Plants are commonly used for treating infectious diarrhea and other gastrointestinal illnesses in these regions, as reliance on biomedical knowledge and pharmaceutical drugs is not always feasible. The same holds true in rural Turkey, although national healthcare clinics are working to provide biomedical services to all regions of the nation. These changes alter medicinal plant use and knowledge. 


\section{Health Care in Turkish Villages}

In 1920, Turkey was one of the first countries in the world to develop a national health ministry (Aydın 1997). The importance of health was symbolized in bodies of post-WWI Turkish citizens and in the figuratively ailing Ottoman sultanate. As new regimes overthrew the old, a political idea of the yeni adam (new man) came into the public imagination (Dole 2004). This idealized man was healthy, hygienic, rational, scientific, and proud to identify himself as a Turk (not an ethnic subgroup). With the 1940’s Kemalist nation-building regime came "a society based upon science, rationality and reason....a society free from, by implication, unscientific, and irrational religiopolitical authority" (Dole 2004:258). The new health initiative emphasized personal hygiene, medical doctors, new pharmaceuticals, and the right to health. However, healthcare clinics took several decades to reach rural Turkish villages and are still sparse in eastern regions.

In many Turkish villages, mothers are usually the first to dispense treatments when illness strikes. They use plants, foods, or other items available around the home. Plant-based remedies for diarrhea are ubiquitous in rural Turkey, with $30 \%$ or more of the pharmacopeias consisting of treatments for gastrointestinal ailments (Honda et al. 1996; Yesilada et al. 1995). Mothers react to illnesses using their knowledge of past experiences and socially-derived concepts about the disease. Some of their disease concepts have been influenced by biomedical experiences such as doctor visits or participation in clinical education programs. Women discuss situations with their friends and neighbors and glean information for future ordeals. The resulting social system of health and disease is similar to other cultural systems (religion, politics, economics, or 
kinship) in that symbolic meanings, social values, and normative behaviors are used to construct knowledge that is shared by the community (Kleinman 1978).

Disease concepts are folk etiologies that describe why a person becomes ill, the symptoms they experience, and the proper response and treatment (Hughes 1968).

Disease concepts involving diarrhea might include biomedical germ theory, Mediterranean cold-hot beliefs, or novel blended theories. People describe symptoms using personally meaningful words and perceptions, and they seek treatments from a range of locally available health specialists including doctors, nurses, herbalists, wise old ladies, imams, and other traditional healers.

In the past, traditional healers were abundant in Turkey. Today, healers are difficult to locate because of political tensions. There are several different specialties, including Koranic healers who are gifted at holy prayers and blessings, either spoken or written (Eyüboğlu 1987). The cinci hoca (genie master) or üfürükçü (anger man) employ spiritual therapies to resolve problems resulting from $\operatorname{cin}$ (jinn, genie, or spirit) possession or harassment. Other healers included the ocaklı (miracle worker), the kurşuncu (lead pourer), the evliya (saint-like person), and the aktar (herbalist) (Dole 2004). Knowledge of each specialty is passed down along familial lines. Today, aktarlar (herbalists) own family-run shops, which supply herbs, tonics, powders, prepared remedies, pastes, and healing balms. Some shops also import European botanical medicines. However, the national government requires herbal shops to maintain pharmaceutical licenses if they are to administer drugs and give advice on remedies.

Turkish villagers have ambivalent attitudes toward herbal remedies. Since plants bear an association with past medical schools and herbaria, plant-based remedies are tenuously legitimated in Turkey. However, in public attitudes, association with 
traditional healing practices antiquates the rigor of herbal remedies and belittles their use and application despite the significant contribution of medicinal plants to people's health. In the 1970s and 1980s, a growing number of pharmaceutical professors in Turkey and Japan began collaborative research on traditional Turkish medicines. Lists of vouchered plants, their preparations, and their treatment procedures were tabulated and published in Turkish and international journals as a way to salvage some of the invaluable Turkish traditional knowledge. For example, Tabata, Honda and Sezik state:

Villagers are the only source of correct and practical information on folk medicine. Other knowledge is generally based on Islamic medicine or European books of phytotherapy. There have been few studies that disclosed the accumulation of folk medicine in villages, and no analytical investigation on such knowledge has yet been carried out [1988:11].

If traditional Turkish knowledge is considered backward and affiliated with religion, Turkish researchers worry that medicinal plant knowledge, since it is considered traditional, will be left by the wayside as the country's politics focus on western, biomedical healthcare. Today, every Turkish citizen has access to subsidized healthcare and medications. Although numbers of doctors, dentists, and hospitals are still low (one doctor for 852 citizens, one dentist for 3900 citizens, and one hospital bed for 396 citizens), the numbers are steadily growing (Ergener 2002). Ethnopharmacologists are concerned that people will opt for biomedical care and forget age-old, regional plantbased remedies (Yeşilada et al. 1999). 


\section{THE FIELD SITE: TURKEY}

For centuries, Turkey has been a physical and cultural bridge between Asia and Europe (Figure 2.1). Today, Turkey is continuing to act as a moderator between the East and West (Göle 2008). World leaders view Turkey as a successful, secular country with a growing economy, a young work force, and much to offer in world politics (Dismorr 2008; Fuller 2008).

Figure 2.1 Map of Turkey, Central Anatolia outlined in gray

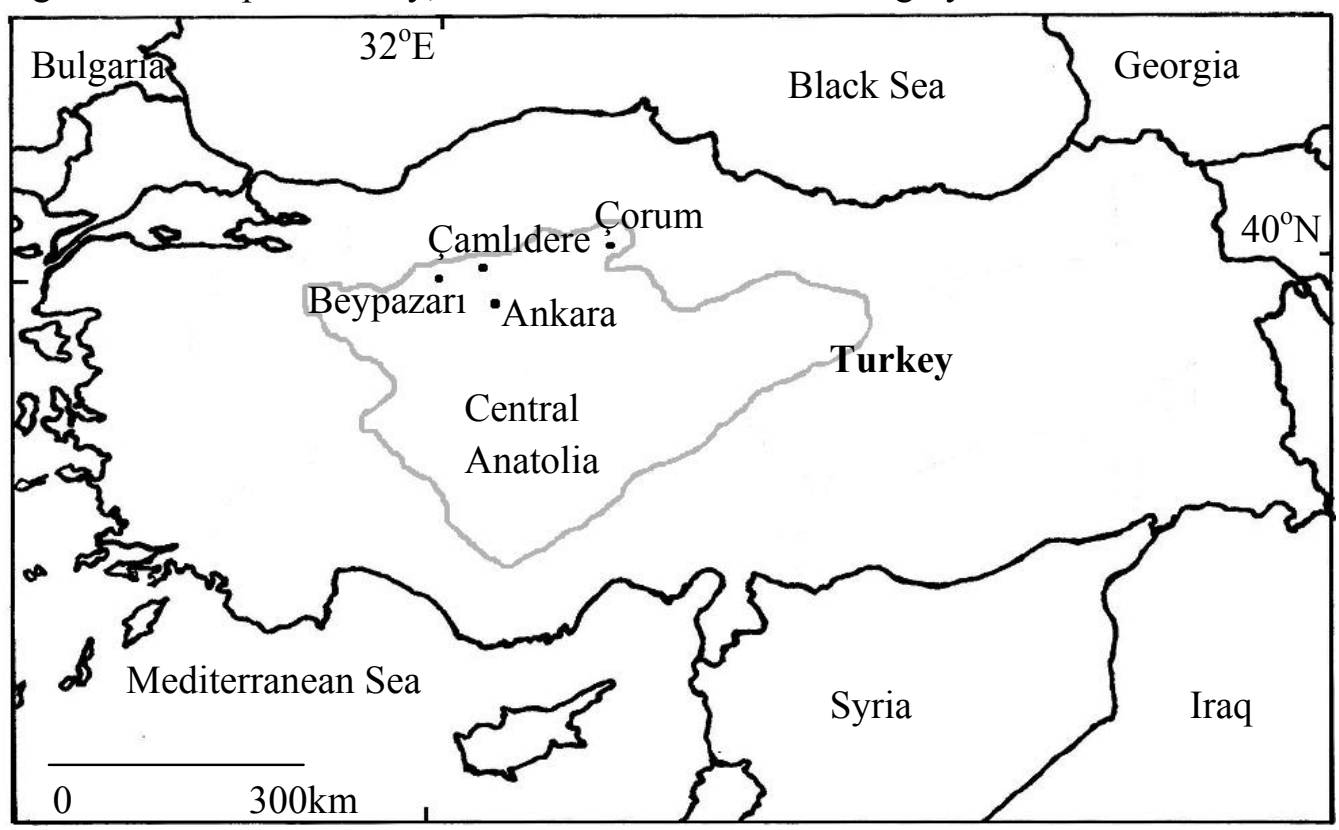

Turkey is situated on the Eastern edges of the Mediterranean and Aegean Seas and the Southern edge of the Black Sea. Neighboring countries include Greece, Bulgaria, Georgia, Armenia, Iran, Iraq, and Syria. While a small portion of Turkey lies in Europe (the $24,378 \mathrm{~km}^{2}$ of Thrace), the rest lies within Asia (Anatolia, 790,200 $\mathrm{km}^{2}$ ). Turkey ranges from $40^{\circ} \mathrm{N}$ to $42^{\circ} \mathrm{N}$ in latitude and $25^{\circ} \mathrm{E}$ to $45^{\circ} \mathrm{E}$ in longitude.

Anatolia is a high plateau bounded on all sides by mountain ranges. Elevation ranges from sea level in the west and steadily rises to $1700 \mathrm{~m}$ in the east. Anatolia is 
divided into six phytogeographic regions (Davis 1965), including Central Anatolia. Central Anatolia ranges from $30^{\circ} \mathrm{E}$ to $38^{\circ} \mathrm{E}$ longitude and $37^{\circ} \mathrm{N}$ to $41^{\circ} \mathrm{N}$ latitude. In the WWF Terrestrial Ecoregion terms, the biome consists of steppe interspersed with mixed conifer and deciduous forests or solely deciduous forests (Olson et al. 2001). According to the Köppen-Geiger climate classification system (Peel, Finlayson and McMahon 2007), the region is predominantly semi-arid steppe (BSk), with a middle latitude temperature range. The climate is hot and dry from July to September. Temperatures average $25^{\circ} \mathrm{C}$ with rainfall less than $10 \mathrm{~mm}$ a month (Atalay 2002). Winters are cold and wet, with average temperatures of $0^{\circ} \mathrm{C}$ from December to February. Rainfall is $40 \mathrm{~mm}$ per month from October through June (Atalay 2002), with annual precipitation at 414mm in Ankara (Ergener 2002).

\section{Demographics and Livelihoods}

Turkey has a population of 72.5 million, according to the 2009 census (Turkish Ministry of the Interior 2010). Three-quarters of the population live in cities (Ergener 2002). Turkey's economy relies on exports of steel and concrete and on agricultural products such as cotton, wool, hazelnuts, apricots, pistachios, citrus, and olives (Ergener 2002). Agriculture is the primary mode of subsistence for Central Anatolian villagers, with approximately $25 \%$ of Turkey's wheat grown in this region (Ergener 2002). Other major crops in the plains of Central Anatolia include barley, oats, lentils, and chickpeas. Sheep are the most common domesticated animal in Turkey $(60 \%)$, but cows and goats are also raised for meat, yoghurt, cheese, and milk (Ergener 2002). 


\section{Language}

Turkish is the official language of Turkey. It is a Ural-Altaic language (Laffont 1995), related to other Turkic languages of Central Asia (Kyrgyzh, Tatar, Azerbaijani, Turkmen, Uyghur). Common characteristics of Turkic languages are agglutination, vowel harmony, non-gendered nouns, and verbs occurring at the end of sentences. During the Ottoman Empire, Arabic script was used, but a reform in 1928 led to the implementation of a phonetic variety of the Latin alphabet which is used currently. Today, 77 million people speak Turkish worldwide (Ergener 2002).

\section{History}

Turkish lands encompass trade routes, water supplies, mountain passes, fertile fields, and natural migratory pathways, over which several peoples and empires have fought throughout the millennia. In 1923, Turkey became a republic. Ever since, Turkey's political drive has pushed blatantly for modernity. Under the guidance of the remarkable Kemal Atatürk, social, political, and economic institutions were completely overhauled in the 1920s, including the health sector (Mango 2002).

Turks first ask about hometowns when meeting a new acquaintance. Rootedness to a fatherland or hometown is very important in Turkish culture (Delaney 1991). Over 30,000 villages dot the countryside of Turkey and each is distinct.

\section{Village Research Sites}

My study took place amongst Turkish villagers in Central Anatolia, in the towns and surrounding rural lands of Beypazarı, Çorum, and Çamlıdere (Figure 2.3). Beypazarı $\left(40^{\circ} 10^{\prime} \mathrm{N}\right.$ by $\left.31^{\circ} 55^{\prime} \mathrm{E}\right)$ is a town of about 34,000 people and a province that covers 1814 
$\mathrm{km}^{2}$ and another 16,400 people. Since it is near Ankara (100 km west), the village is in a dynamic relationship with the capital, promoting day trips and shopping sprees for urbanites in the village market. Beypazarı is home to two museums, many silver shops, and is well known for its sweet carrots.

Çorum is a large city of 212,000 people on the northeastern edge of Central Anatolia $\left(40^{\circ} 32^{\prime} \mathrm{N}\right.$ and $\left.34^{\circ} 57^{\prime} \mathrm{E}\right)$. It is $244 \mathrm{~km}$ east of Ankara on a high plateau $(800 \mathrm{~m})$, with mountains blocking northern passage to the Black Sea. The province of Çorum covers $12,800 \mathrm{~km}^{2}$ with 580,000 people who work in agricultural or industrial sectors. Çorum is famous for its dried chickpeas (leblebi).

Çamlıdere is located $100 \mathrm{~km}$ northwest of Ankara $\left(40^{\circ} 29^{\prime} \mathrm{N}\right.$ and $\left.32^{\circ} 29^{\prime} \mathrm{E}\right)$. It is known for its petrified forests, rolling hills, and a beautiful lake that is the source of drinking water for Ankara. About 6300 people live in the town while 15,339 people live within the district of $633 \mathrm{~km}^{2}$.

Figure 2.3 Survey participants near Çamlıdere

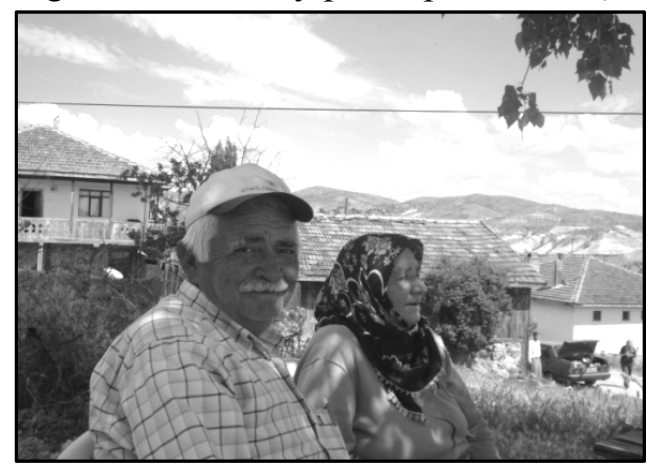

Of importance, Turkish villagers, not city-dwellers, were interviewed for this study. Urban lifestyles are very different from village life, although numerous similarities exist in basic beliefs and cultural nuances. Village life is considered closed, endogamous, 
and self-sufficient, and the disjunction between rural and urban Turks is socially marked in daily conversations, TV shows, and even manners of greeting or presenting oneself.

Most villagers in Central Anatolia are Sunni Muslims (with a heritage descended from Fatima, a daughter of Mohamed the Prophet). However, Alevi Muslims are influential in eastern portions of Central Anatolia. The Alevi are a special sect of Muslims who maintain some Turkic Central Asian traditions of mysticism, nomadism and shamanism. Many Sunni do not consider the Alevi to be truly Muslim; this is a source of political tension in Turkish society.

\section{Aims of Study}

This study aimed to 1) determine folk concepts and classification of diarrheal diseases in Central Anatolia, 2) identify perceived causes of diarrhea (i.e., folk etiologies), 3) determine botanical treatments for diarrhea, and 4) determine whether the present use of plants differs from plants reported in previous Turkish ethnobotanical studies. Hypotheses included: H1. Rural inhabitants of Central Anatolia treat diarrhea with plantbased remedies, and $\mathrm{H} 2$. The Central Anatolian anti-diarrheal pharmacopeia changes over time.

\section{METHODS}

\section{Interviews}

To gather folk concepts, classifications, and etiologies of diarrheal diseases, I conducted informal, semi-structured interviews with Turkish villagers in Central Anatolia. Fieldwork was undertaken for one year (from September 2008 to 2009) with the assistance of a J. William Fulbright Foreign Scholarship Award and the Turkish 
Fulbright Commission. I selected the capital city of Ankara, Turkey, for permanent residence because of its central location and because my sponsoring institution, Gazi University, was situated in Ankara.

Prior informed consent was obtained verbally for each interview session (FIU IRB Approval No. 082508-01). Ethical guidelines of the American Anthropology Association and the Society for Economic Botany were followed during the course of research.

I visited Çorum, Çamlıdere, and Beypazarı multiple times during the Spring (April to June) of 2009. As it was important to establish contacts before visiting a village, these areas were selected because of collaborators (Evrim Özünel and Sema Demir) who were from these areas and because professors (İlhan Gübüz and Ekrem Sezik) in the Pharmacy Department at Gazi University had access from previous studies.

In the villages and surrounding rural areas, I first visited the market or the mayor's home to drink tea, discuss research goals, and conduct an interview with the family. Using snowball sampling techniques, other homes in the area or tables in the markets were visited. Culturally, it was difficult to interview people of the opposite sex and to interview people individually. Thus, most interviews were held in small groups of two to seven women.

Interviews were conducted in Turkish. Collaborators were present to assist in the flow of conversation and later interpretation. Semi-structured questionnaires (Appendix 1 and 2) were translated, checked for cultural relevancy, and back-translated with the assistance of Turkish collaborators. Questions were asked about diarrhea, illness scenarios (e.g., If your child has diarrhea, what do you do?) and plant-based treatments.

Free-listing exercises and saliency ranking techniques (Alexiades 1996, Nolan 2001, Quinlan 2010) were performed with every group interview. While saliency is 
normally calculated for individual informants, the formula was modified to analyze a small group's comments and listings. The formula for saliency ranking is

$$
\mathrm{s}_{\mathrm{i}}=\frac{\text { inverse rank order of item }}{\mathrm{N} \text { of items listed }}
$$

Each group's free-listed items were ranked in order and then inversely valuated according to the total number of items listed for that question or concept. Then the composite saliency (S) for every listed item from all groups was calculated to determine the intracultural saliency of each item.

$$
\text { Composite } \mathrm{S}=\frac{\sum \mathrm{s}_{\mathrm{i}}}{\mathrm{N}_{\mathrm{i}}}
$$

Items with the highest composite saliency values are those that villagers are most likely to think about first. Free listing exercises were conducted to discover the most prominent names for diarrhea, the types and classification of diarrhea, culturally relevant causes of illness, and preferences for botanical treatments.

\section{Demographics}

The sex, age, marital status, parental status, and grandparental status were collected from one person in each group interview. The person's time of residence in the village was recorded along with other locations of residence and time spent elsewhere. Class and ethnicity were not recorded, as these categories are not locally relevant.

\section{Literature Review of Turkish Ethnobotanical Resources}

To better understand folk illnesses and plant-based remedies, I conducted a literature review of Turkish resources. While several articles involving Turkish medicinal plants are available in international journals, I reviewed reports that were difficult to 
acquire while in residence at Gazi University. I only included publications that reported vouchers and expert botanical identifications (Ertuğ, 2000; Fujita, et al., 1995; Honda, et

al., 1996; Özgökçe and Özçelik, 2004; Sezik, et al., 1991; Sezik, et al., 1992; Sezik, et al., 1997; Sezik, et al., 2001; Simsek, et al., 2004; Tabata, et al., 1994; Tuzlacı and Aymaz, 2001; Tuzlacı and Tolon, 2000; Yeşilada, et al., 1993; Yeşilada, et al., 1995; Yeşilada, et al., 1999).

\section{Botanical Specimens}

Following interviews, medicinal plants were gathered from fields, gardens, and roadsides. I recorded GPS coordinates and habitat information for each plant specimen. For taxonomic identification, I used the 11 volumes of the Flora of Turkey (Davis 1965, Güner, et al. 2001) along with the taxonomic expertise of Zeki Aytaç and Ufuk Özbek from the Botany Department at Gazi University. The Angiosperm Phylogeny Group (APG III 2009, Stevens 2001 onwards) was used for familial nomenclature. I prepared and deposited 43 voucher specimens in GAZI.

\section{RESULTS}

\section{Interviews}

Over 130 participants (Table 2.1) were interviewed in 46 small-group sessions. Key informants and collaborators in research included two doctoral graduate students (Sema Demir and Evrim Özçelik) from Gazi University’s Folklore Department. 
Table 2.1 Demographic results for group interview participants

\begin{tabular}{|c|c|c|c|c|c|c|c|}
\hline Age & Gender & Marital & atus & Paren & Status & Reside & \\
\hline \multirow{2}{*}{$\begin{array}{l}\text { Range: } \\
26 \text { to } 72\end{array}$} & \multirow[t]{2}{*}{ Female $87 \%$} & Married & $87 \%$ & \multirow[t]{2}{*}{ Parent } & \multirow[t]{2}{*}{$91 \%$} & \multirow[t]{2}{*}{ Local } & \multirow[t]{2}{*}{$52 \%$} \\
\hline & & Widowed & $7 \%$ & & & & \\
\hline \multirow[t]{2}{*}{ Ave $=46.3$} & \multirow[t]{2}{*}{ Male $\quad 13 \%$} & Single & $2 \%$ & \multirow{2}{*}{\multicolumn{2}{|c|}{$\begin{array}{l}\text { Grand- } \\
\text { parent }\end{array}$}} & \multirow{2}{*}{$\begin{array}{l}15+\text { yrs } \\
\text { Resident }\end{array}$} & \multirow{2}{*}{$91 \%$} \\
\hline & & No Reply & $4 \%$ & & & & \\
\hline
\end{tabular}

From the ranking and free listing exercises, several ideas and concepts about diarrhea were obtained. The common name for diarrhea (ishal) did not differentiate between desired diarrhea, as in the case of constipation, and undesirable diarrhea, as in illness. Therefore, I learned to use alternative, locally appropriate words for undesired diarrhea (Table 2.2). These referred to amel (the deed) or bozulma (broken) intestines. Another name was descriptive of the sound of diarrhea ( $\mathrm{Clr} \mathrm{clr}$, pronounced jur jur). Inappropriate names were not gathered systematically.

Table 2.2 Common names for diarrhea

\begin{tabular}{|l|l|}
\hline $\begin{array}{l}\text { Turkish Names } \\
\text { for Diarrhea }\end{array}$ & $\begin{array}{l}\text { English } \\
\text { Translation }\end{array}$ \\
\hline İshal & Diarrhea \\
\hline Amel & The Deed \\
\hline Cir cır & Onomatopoeia \\
\hline Bozulma & Broken \\
\hline Ötürük & $\begin{array}{l}\text { After constipation } \\
-- \text { desirable }\end{array}$ \\
\hline
\end{tabular}

When people were asked to free list the types of diarrhea they knew, their responses overwhelmingly ranked poisonous diarrhea (zehirli ishal) first (Table 2.3). Participants animatedly discussed how horrible and deadly it was. Symptoms included black or green diarrhea, with occasional vomiting or fever. Even though many cases of 
diarrhea were normal and not poisonous, the poisonous type was feared because of the unknown source of poison, severity of disease, and high rate of mortality.

Table 2.3 Ranked salient types of diarrheal disease

\begin{tabular}{|l|l|c|l|}
\hline Turkish Terms & $\begin{array}{l}\text { Translated } \\
\text { Terms }\end{array}$ & Saliency & Symptoms \\
\hline zehirli ishal & Poison & 1.647 & $\begin{array}{l}\text { Green or black, deadly, sometimes fever or } \\
\text { vomiting }\end{array}$ \\
\hline kanlı olur & Bloody & 0.677 & Red blood in stool, weakness \\
\hline Sulu & Watery & 0.147 & High volume, colorless \\
\hline Normal & Normal & 0.118 & Cramping, powerful urge \\
\hline
\end{tabular}

When asked about causes of diarrheal disease, villagers mentioned 22

possibilities. There was high saliency in the first seven causes mentioned (Table 2.4) and less consensus in the remainder. Interviewees mentioned being cold or having cold feet as the primary cause of diarrhea and illness in general. Causes associated with germ theory were highly ranked and included concepts such as dirty hands when preparing food, microbes in food or water, food that had spoiled, and dirty water. Sun poisoning and eating oily foods were ranked next in saliency for causes of diarrhea.

Table 2.4 Ranked causes of diarrhea (22 total)

\begin{tabular}{|c|l|l|}
\hline Rank & Top 10 Causes & Saliency \\
\hline 1 & Being cold, feet are cold & 0.472 \\
\hline 2 & Dirty food preparation & 0.306 \\
\hline 3 & Microbes & 0.278 \\
\hline 4 & Spoiled food & 0.250 \\
\hline 5 & Drink unhealthy water & 0.222 \\
\hline 6 & Heat, sun poisoning & 0.194 \\
\hline 7 & Eat oily foods & 0.181 \\
\hline 8 & Eat Dried Apricots, Prunes & 0.069 \\
\hline 9 & Evil Eye & 0.042 \\
\hline 9 & Sit in dirt & 0.042 \\
\hline 9 & Eat green chickpeas & 0.042 \\
\hline
\end{tabular}




\begin{tabular}{|c|l|l|}
\hline 9 & Broken inside & 0.042 \\
\hline 9 & From things we eat & 0.042 \\
\hline 9 & Eat junk food-nuts, chocolate & 0.042 \\
\hline 9 & Don't eat bread with sour things & 0.042 \\
\hline 9 & When salt and water lost from body & 0.042 \\
\hline 10 & Sugar overdose in children & 0.028 \\
\hline 10 & Teething babies & 0.028 \\
\hline 10 & Drink tea with milk & 0.028 \\
\hline 10 & Eat dried beans & 0.028 \\
\hline 11 & Eat too much pestili, or dried fruit roll & 0.014 \\
\hline 11 & Eat unhealthy foods & 0.014 \\
\hline
\end{tabular}

The free-listing of salient treatments of diarrhea identified 44 plant-based remedies, including foods and wild plants (Table 2.5). The differentiation between foods and wild plants was acquired from interviewees. Food plants were called by their specific household names (lemons were limonlar), but wild plants were called yabanıl (wild, uncultivated) or deemed yayla'dan (from the countryside, summer grazing lands, or nearby fields). Therefore, the translated term wild was used to indicate uncultivated plants collected outside in a variety of locations.

Many women listed food items that were readily available in their homes for treating diarrhea. Half the groups only listed food items (e.g., potatoes, rice, coffee), and $38 \%$ of the groups mentioned both foods and wild plants used to treat diarrhea. Of these, $58 \%$ preferred to use wild plants instead of foods when treating diarrhea, and the remaining $42 \%$ preferred food-based treatments. Only $8 \%$ of the interview groups listed solely wild plants for treatments, and $4 \%$ went straight to a doctor without using any plant-based remedies. All participants said that after a day or two with no improvement, they would take a child suffering from diarrhea to a nearby clinic or doctor. 
Table 2.5 Ranked treatments for diarrhea (44 total)

\begin{tabular}{|c|c|c|}
\hline Rank & Treatments & Saliency \\
\hline 1 & Boiled Potato & 0.677 \\
\hline 2 & Coffee Powder (with lemon, salt) & 0.647 \\
\hline 3 & Pirinç, or watery rice soup & 0.588 \\
\hline 4 & Cola syrup or flat soda & 0.459 \\
\hline 5 & Yogurt, Torba yoğurt, Ayran & 0.406 \\
\hline 6 & Övez or Yuvaz, Sorbus domestica fruits & 0.288 \\
\hline 7 & Dry tea (with honey) & 0.282 \\
\hline 8 & Salt-Sugar-Water Solution (ORT) & 0.247 \\
\hline 9 & Lemon wedge with salt & 0.241 \\
\hline 10 & Mint-Honey-Lemon Water & 0.212 \\
\hline 11 & $\dot{I}$ ğde, Elaeagnus angustifolia & 0.200 \\
\hline 12 & Muz, banana & 0.171 \\
\hline 13 & Pestil, dried Cornus mas fruit paste & 0.159 \\
\hline 13 & Lemon and vinegar mix & 0.159 \\
\hline 14 & Water, ample amounts & 0.147 \\
\hline 15 & Leblebi, or dry roasted chickpeas & 0.130 \\
\hline 16 & Aspirin, with cola or coffee & 0.124 \\
\hline 17 & Lemon, eaten & 0.118 \\
\hline 18 & Maya, yeast, drunk or eaten & 0.106 \\
\hline 19 & Şeftali, peach juice or peel & 0.100 \\
\hline 20 & Ihlamur, Tilia spp. & 0.094 \\
\hline 20 & Karaçall, Ulex europaeus & 0.094 \\
\hline 21 & Yavșan otu, Artemisia vulgaris & 0.077 \\
\hline 22 & Garlic cloves, swallowed & 0.047 \\
\hline 23 & Ŏgul otu, Melissa officinalis & 0.041 \\
\hline 23 & Papatya, chamomile varieties & 0.041 \\
\hline 23 & Apple, peeled and boiled & 0.041 \\
\hline 23 & Nişasta, starch, drunk & 0.041 \\
\hline 23 & Acr gevendikeni, Astragalus spp. & 0.041 \\
\hline 24 & Istrgan, Urtica dioica & 0.035 \\
\hline 24 & Parl yavșan, Teucrium polium & 0.035 \\
\hline 24 & Kekik, oregano or thyme & 0.035 \\
\hline 24 & Hot water from local natural spring & 0.035 \\
\hline 24 & Breast milk for baby & 0.035 \\
\hline 24 & $U n$, flour, drunk & 0.035 \\
\hline 24 & Honey, in cold water & 0.035 \\
\hline 24 & Warm feet & 0.035 \\
\hline 24 & Salt in bag, on stomach & 0.035 \\
\hline 24 & Butter biscuits & 0.035 \\
\hline 24 & Salted crackers & 0.035 \\
\hline 24 & Dried apricots & 0.035 \\
\hline 24 & Coffee lokum, Turkish delight & 0.035 \\
\hline 24 & Bread, with butter and fruit jam & 0.035 \\
\hline
\end{tabular}




\begin{tabular}{|l|l|l|}
\hline 24 & Apple vinegar & 0.035 \\
\hline
\end{tabular}

Women rarely gave coffee to their children during diarrheal episodes, but they often treated themselves or their spouses with a spoonful of coffee powder, usually mixed with lemon and salt. A similar mixture of powdered tea leaves and honey was used, as were mixtures of lemon juice and salts or vinegar and lemons.

The ten most salient treatments for diarrhea included commonly available household food items. However, almost every interview discussed one or more plants collected in fields or along roadways. While not sown outright, a few plants such as isirgan (stinging nettle), papatya (chamomile), and kekik (oregano or thyme) were fostered to grow in their places of germination, including backyard gardens and orchards. A list of plants collected from the outdoors is available in Table 2.6. Herbs were also purchased in markets or as spices in grocery stores, but these were not collected as voucher specimens or bulk samples.

Table 2.6 Plants collected outdoors, ranked by saliency, 13 of 21 plants

\begin{tabular}{|l|l|l|l|}
\hline Turkish Name & English Name & Latin Name & Family \\
\hline övez & service tree & Sorbus domestica L. & Rosaceae \\
\hline nane & mint & $\begin{array}{l}\text { Mentha longifolia } \text { (L.) } \\
\text { Huds. }\end{array}$ & Lamiaceae \\
\hline iğde & oleaster & Elaeagnus angustifolia L. & Elaeagnaceae \\
\hline pestil & cornelian cherry & Cornus mas L. & Cornaceae \\
\hline hlamur & linden tree & $\begin{array}{l}\text { Tilia cordata } \text { Mill., } \\
\text { T. tomentosa } \text { Moench }\end{array}$ & Malvaceae \\
\hline karaçal1 & gorse, furze & Ulex europaeus L. & Fabaceae \\
\hline yavşan otu & mugwort & Artemisia vulgaris L. & Asteraceae \\
\hline oğul otu & lemon balm & Melissa officinalis L. & Lamiaceae \\
\hline papatya & chamomile & $\begin{array}{l}\text { Anthemis tinctoria } \text { L., } \\
\text { A. coelopoda } \text { Boiss. }\end{array}$ & Asteraceae \\
\hline gevendikeni & vetch & Astragalus spp. & Fabaceae \\
\hline par yavşan1 & germander & Teucrium polium L. & Lamiaceae \\
\hline kekik & oregano, thyme & $\begin{array}{l}\text { Origanum } \text { spp., } \\
\text { Thymus } \text { zygoides } \text { Griseb. }\end{array}$ & Lamiaceae \\
\hline 1sirgan & stinging nettle & Urtica dioica L. & Urticaceae \\
\hline
\end{tabular}


All the plants were prepared as infusions, decoctions or teas. Fruits such as övez and $i \breve{g} d e$ were eaten fresh or boiled and drunk. Pestil was boiled, mashed, and dried as a fruit roll-up for storage until winter months. It was either eaten or melted in hot water as a tea. All of the plants were collected and available for sale in local markets in dried forms, just as people were able to collect the plants for themselves from the nearby landscape.

\section{Literature Review of Plants}

The literature review identified 155 different uses of 91 species of plants from 33 families to treat gastrointestinal illnesses. Since each literary source had its own method of categorizing illnesses or use patterns, categories such as diarrhea, colitis, abdominal pain, intestinal pain, abdominal cramping, stomachache, stomach upset, gastrointestinal ailments, and nausea were tabulated. Of these citations, 77 uses of 53 species from 25 plant families directly mentioned diarrhea as an illness and use category (Appendix 3).

\section{Botanical Specimens}

Forty-three vouchers of 35 plant species from 20 families were collected during fieldwork with informants. Voucher specimens were collected during flowering season; fruits were collected when available. 


\section{DISCUSSION}

\section{Folk Concepts of Diarrheal Diseases}

\section{Types of Diarrhea}

The most salient type of diarrhea among the villagers was the green or black poisonous kind. The symptoms of poisonous diarrhea are similar to those described in biomedical text books as bacteria-induced diarrhea, caused by small intestinal infections and toxins from Salmonella, E. coli, Shigella, Yersinia and Campylobacter species (Fenoglio-Preiser et al. 1999). The green color occurs because of un-processed green bile secretions from the upper small intestines which normally turn brown during transit. The black color results from blood that is acidified, as in the acidic environment of the upper small intestine (Navaneethan and Giannella 2011).

Bloody diarrhea can be linked to bacterial infection of the intestines, as well. Most cases of bacillary dysentery, caused by Shigella species, lead to blood in the stool as bacteria lyse and kill the epithelial lining of the intestines (Fernandez and Sansonetti 2003). Watery diarrhea can be caused by too many salts or fats in the colon (from a big meal). A more serious form of watery diarrhea is caused by bacterial infection and toxin release, such as toxins produced by E. coli, Vibrio cholerae, V. parahaemolyticus, or Campylobacter jejuni. In neighboring Bulgaria, the most common causes of diarrhea in children are rotaviruses (31\%), followed by bacteria (20\%), with Salmonella, E. coli, Shigella, Campylobacter, and Yersinia species comprising the most cases, in that order (Nedkova et al. 2008). Considering that $20 \%$ of global deaths of children under the age of five (Zhang 2008), and 10\% of infant deaths in Turkey (Ergener 2002) are caused by infectious diarrhea, the fear of poisonous diarrhea in villages is understandable. 


\section{Causes of Diarrhea}

The most salient cause of diarrhea for village women was cold feet. Throughout Turkey, wearing shoes and slippers is believed to ward off illness, as is keeping the body warm in general. Guests are given slippers and tea upon arrival, and outdoor shoes are not permitted inside the living area of a home. When asked about the use of slippers, some people stated that a lot of heat is lost by the feet and head, so they must be covered. Women also mentioned the need to protect themselves from cold winds, some with names, which blow over the Central Anatolian plains and bear good or bad influences into the region.

The second through fifth most salient causes of diarrhea were related to biomedical germ theory. Women often mentioned and quoted national healthcare education campaigns in which they were taught healthy hand washing techniques and food storage practices. Bad water was also discussed frequently as dirty water opposes religious notions of purity. Some villages were well-known for their healing waters, with springs linked to activities of past saints. In these locations, villagers maintained large waterworks for people (and animals) to stop and drink. Healthy water was described as a critical resource in both mundane and religious matters.

Sun poisoning or sunstroke was discussed as a cause of diarrhea, and several plants in Turkish pharmacopeias are used to treat it. Since most villagers have agricultural livelihoods, sunstroke affects many people. Most field workers are women, and women remain covered for cultural reasons and to prevent sunburn and chapped skin from winds. The month of fasting, Ramadan, proves a difficult period for laborers when it falls during the agricultural season, as sunstroke becomes more prevalent. 
Other causes of diarrhea mentioned by villagers included consumption of certain foods or practices such as sitting in the dirt or not drinking hot tea after a big meal. Evil eye was also cited as a cause of diarrhea and a source of a numerous afflictions in Turkish culture. Glass beads that resemble blue eyes (mavi boncuklar or blue beads) are frequently worn as protection from jealous glances and evil stares. The bead is thought to take the cursing glance in place of the person wearing it. If one is caught without protection, the evil eye can bring on difficulties such as diarrhea.

\section{Treatments for diarrhea}

Since many cases of diarrhea are self-limiting, treatments such as bland foods usually are sufficient in sustaining the sufferer through a bout. Villagers commonly gave a boiled potato to a person with diarrhea. The potato was thought to bind up contents of the intestines, making them less watery and adding bulk. In biomedical reports, small quantities of starchy or fibrous foods relieve cramping during diarrhea (Lewis and ElvinLewis 2003). The adult treatments involving coffee grounds, lemons, salts, vinegar, or dried tea leaves probably lead to a drastic increase in acidity of the GI tract and possibly act as a diuretic, an intestinal muscle stimulant, or denature bacterial toxins to end an infection in the gut.

A watery rice soup preparation was described in health education campaigns, as were sugar-salt solutions. Women explained that these treatments were often used to treat children's diarrhea, with good results. Yoghurt, a staple food in the Turkish diet, was used to settle upset stomachs as well as diarrhea. Varieties of mints were found in the fields or roadsides and were often collected for teas or infusions. People ate 10-15 iğde (Elaeagnus angustifolia) fruits to treat diarrhea and stored them for use in winter. 
Comparing the results of the ethnobotanical literature review with the plants listed by villagers in this study, seven plants were mentioned (Camellia sinensis, Cicer arietinum, Coffea arabica, Cornus mas, Sorbus domestica, Teucrium polium, and Urtica dioica). The literature review covered all of Turkey, while the present research covered only Central Anatolia. Turkish phytogeography is diverse, and several plant species do not occur in multiple regions. Only two previous studies covered the pharmacopeias of Central Anatolia (Honda, et al., 1996, Sezik, et al. 2001) and of Ankara (Simsek, et al. 2004). Besides the seven plants mentioned above, these sources listed eight other botanical treatments for diarrhea: Rhus coriaria L., Viscum album L., Rumex patientia L., Punica granatum L., Cydonia oblonga L., Pyrus ealaeagnifolia L., Rosa canina L, and Lycopersicon esculentum Mill.

While previous researchers collected entire repertoires of medicinal plants for all diseases, I asked specifically about diarrheal diseases and related treatments. Also, I geared my questions to collect information on all types of botanical remedies, including foods and wild plants, as I wanted to know exactly how local women treated diarrhea. Other ethnobotanical studies might have focused more on wild plants. Nonetheless, plants used as treatments today are from similar families as those reported in the literature, although over half of the published plants used in the past were not mentioned in the recent village interviews.

Women who collected plants tended to be older (40+ years). They viewed a collecting trip as a wonderful way to spend a spring or autumn day outdoors, when plants would be ripe for harvest. Women went out with friends and children to locations where specific plants and trees were known to grow. Locales included narrow forest plots that lined fields outside the villages, fencerows, or road edges along expansive non- 
agricultural plains. Some women also nurtured opportunistic plants in their gardens, orchards, or backyards. For the town markets, the men of Beypazarı worked together to collect wild plants while the women sat in the market, tending booths.

When I asked about specialists who might know of herbal remedies, interviewees responded that such specialists existed in the past but died 10 to 15 years ago. If they wanted specialist knowledge now, they consulted popular books on herbal remedies, of which there were many for purchase at bookstores, or they might look on-line at Turkish herbal websites. Many women noted that it was just as easy to go to the clinic or call a doctor as to find an herbalist nearby. Younger women in group discussions knew fewer plant-based remedies (wild or food plants) and often argued within groups that water, oral rehydration therapy (ORT), and doctor visits were the best ways to treat diarrhea, especially for children. This aligned with WHO and government health campaign information.

Turkish women are dealing with changes in healthcare regimes at the local, national, and even global levels. Women who attend health education campaigns gain knowledge that shapes their perceptions of disease and, by extension, their practices in treating it. With more local clinics available, women are able to visit doctors more easily. Nationally, the government has worked for years to instill in its citizens the need for better healthcare, which translates directly into biomedical healthcare. Doctors and staff with biomedical training are esteemed and their advice is highly regarded by villagers. Turkey has been working to expand its healthcare system for decades, to improve its citizens' health and also to meet global EU, IMF, and other multilateral corporations' expectations. Additionally, diarrhea was one of the leading topics for social health reform of the UN and UNICEF in the 1990s. As such, diarrheal disease and its management 
have received considerable attention in countries such as Turkey. The effects of these global, multilateral forces can be seen in local village women's changing ethnobotanical knowledge and practices.

\section{CONCLUSIONS}

Central Anatolian villagers have a malleable, shifting understanding of gastrointestinal disease, influenced by recent biomedical education campaigns along with traditional village beliefs and practices. With the implementation and growth of federal health care programs and UN health education campaigns in Turkey, mothers have the option, and are encouraged, to seek medical care in cases of acute diarrhea instead of using home remedies. These and other factors are altering the folk classifications for gastrointestinal diseases as well as the ethnobotanical knowledge used to treat diarrhea in rural communities.

Currently, villagers include biomedical paradigms such as microbe theory, food preparation, and dirty water along with folk theories involving the evil eye or hot/cold values as salient causes of diarrheal illness. Common treatments include foods immediately available in the home as well as plants collected nearby. Therapies may also involve prayers or blessings from powerful Koranic scriptures.

As is common in ethnobotanical studies, older participants ( $>40 \mathrm{yrs})$ knew more treatments for diarrhea in general, including more wild (yabanıl) plant-based remedies. They readily offered a variety of treatments in group discussions. Several had sheets of pestil ready for use, and others sold plants as herbs and spices in the market. This difference in age might be explained by older mothers having greater mobility, as their children are older and able to collect plants for or with them. As older women with more 
children, they also have a more established position in the family, which enables them to leave the home more freely.

A minority of younger participants opined that no home treatment of any sort except water or ORT should be used in the case of diarrhea, especially for children. They preferred to immediately go to the clinic and seek professional help. However, most women (96\%) agreed that some plant-based remedy, whether food or not, should be used to treat diarrhea. Women also said that they discussed these topics with their peers and family members, and they saw infomercials during their favorite television shows advocating for healthy Turkish children. Younger women have grown up going to school, seeing the doctor, watching television, and generally accruing more experience with foreign commodities and livelihoods. The older women grew up working more in the fields. They were more intimately exposed to the plants lining the roadways and field edges and have a different relationship with the land in their village.

Today, traditional knowledge in Turkey is treated ambivalently. Sometimes traditions are berated for being backward. At other times, traditions are deemed the heritage and birthright of every Turk. Often, anthropologists define traditional knowledge as a knowledge system preceding colonization or as a social perception of old-versus-new ways of life. Turkish definitions of traditions involve constant use and change. Turkish traditions are equated to air (Glassie 1993). Everyone in a close-knit group has to breathe, and eventually, they exchange air by inhaling and exhaling. People take what they need from the air (ideas, nourishment, or artistic styles), change it, and release it. Understanding Turkish perceptions of traditional knowledge is important for better understanding the acceptance and expectations of constantly changing trends and trajectories in local knowledge, including medicinal plant knowledge. Change is normal, 
unsurprising, and even anticipated in this context, albeit constrained somewhat by cultural values.

When considering diarrheal disease concepts, Turkish villagers act and change at a local or individual level while they are informed by national and global media to treat diarrhea in specific ways. While some women still know of wild or food medicinal plants used to treat diarrhea, the actual use of plants and transmittance of this knowledge appears to be waning as the national healthcare system becomes entrenched in the daily lives of Turkish villagers. Understanding this multi-level process is a first step in addressing the future needs of Turkish villagers and re-setting ethnobotanical theory to address these concerns.

\section{REFERENCES}

Agunua, A., S. Yusuf, G. O. Andrew, A. U. Zezi and E. M. Abdurahman 2005 Evaluation of five medicinal plants used in diarrhoea treatment in Nigeria. Journal of Ethnopharmacology 101: 27-30.

Alexiades, M. 1996 Selected Guidelines for Ethnobotanical Research: A Field Manual. Bronx, NY: The New York Botanical Garden Press.

APG III.

2009 An update of the Angiosperm Phylogeny Group classification for the orders and families of flowering plants: APG III. Botanical Journal of the Linnean Society 161: 105-121.

Atalay, I.

2002 Coğrafya Atlasi. Istanbul: Inkilap Kitabevi.

Aydin, E.

1997 Türkiye'de Tasra ve Kirsal Kesim Sağlik Hizmetleri Örgütlenmesi Tarihi. Toplum ve Hekim 12(80): 21-44.

Berlin, E. and B. Berlin 
1996 Medical Ethnobiology of the Highland Maya of Chiapas, Mexico: The Gastrointestinal Diseases. Princeton, NJ: Princeton University Press.

Davis, P. H.

1965 Flora of Turkey and the East Aegean Islands. 11 vols. Edinburgh: Edinburgh University Press.

Delaney, C.

1991 The Seed and the Soil: Gender and Cosmology in Turkish Village Society. Berkeley: University of California Press.

Dismorr, A.

2008 Turkey Decoded. London and Beirut: SAQI.

Dole, $\mathrm{C}$.

2004 In the Shadows of Medicine and Modernity: Medical Integration and Secular Histories of Religious Healing in Turkey. Culture, Medicine and Psychiatry 28: 255-280.

Ergener, R. 2002 About Turkey: Geography, Economy, Politics, Religion, and Culture. Boulder, CO: Pilgrims' Process, Inc.

Ertuğ, F.

2000 An ethnobotanical study in Central Anatolia (Turkey). Economic Botany 54: 155-182.

Eyüboğlu, I. Z. 1987 Anadolu Halk Ilaçları. Istanbul: Gecit Kitabevi.

Fawole, O. A., A.R. Ndhlala, S.O. Amoo, J.F. Finnie, and J. Van Staden 2009 Anti-inflammatory and phytochemical properties of twelve medicinal plants used for treating gastro-intestinal ailments in South Africa. Journal of Ethnopharmacology 123: 237-243.

Fenoglio-Preiser, C. M., A. E. Noffsinger, G. N. Stemmermann, P. Lantz, M. Listrom and F. Rilke

1999 Gastrointestinal Pathology: An Atlas and Text. $2^{\text {nd }}$ edition. Philadelphia: Lippincott-Raven Publishers.

Fernandez, M. I. and P. J. Sansonetti 2003 Shigella interaction with intestinal epithelial cells determines the innate 
immune response in shigellosis. International Journal of Medical Microbiology 293: 55-67.

Fujita, T., E. Sezik, M. Tabata, E. Yeşilada, G. Honda, and Y. Takeda 1995 Traditional medicine in Turkey VII. Folk medicine in middle and west Black Sea Regions. Economic Botany 49: 406-422.

Fuller, G. E.

2008 The New Turkish Republic: Turkey as a Pivotal State in the Muslim World. Washington, D.C.: United States Institute of Peace Press.

Glassie, H.

1993 Turkish Traditional Art Today. Bloomington, IN: Ministry of Culture of the Turkish Republic and Indiana University Press.

Göle, N.

2008 İç İçe Girişler: İslam ve Avrupa. İstanbul: Metis.

Güner, A., N. Ozhatay, T. Ekim, K. Husnu, C. Baser and I. Hedge 2001 Flora of Turkey and the East Aegean Islands. Vol. 11. Edinburgh: Edinburgh University Press.

Heinrich, M., H. Rimpler and N. A. Barrera 1992 Indigenous Phytotherapy of Gastrointestinal Disorders in Lowland Mixe Community (Oaxaca, Mexico): Ethnopharmacologic Evaluation. Journal of Ethnopharmacology 36: 63-80.

Honda, G., E. Yeşilada, M. Tabata, E. Sezik, T. Fujita, and Y. Takeda 1996 Traditional medicine in Turkey VI. Folk medicine in West Anatolia: Afyon, Kütahya, Denizli, Muğla, Aydın Provinces. Journal of Ethnopharmacology 53: 7587.

Hughes, C. C.

1968 Ethnomedicines. In International Encyclopedia of the Social Sciences, vol 10. Pp. 87-93. New York: Free Press/MacMillan.

Kleinman, A.

1978 Concepts and a Model for the Comparison of Medical Systems as Cultural Systems. Social Science and Medicine 12: 85-93. 
Laffont, R.

1995 Les Langages de L’Humanité: Une Encyclopédie des 3.000 Langues Parlées dans le Monde. Paris: Seghers.

Lewis, W. and M. Elvin-Lewis 2003. Medical Botany: Plants Affecting Human Health. New York: John Wiley Interscience.

Mango, A.

2002 Ataturk: The Biography of the Founder of Modern Turkey. New York: Overlook, TP.

Mathabe, M. C., R. V. Nikolova, N. Lall and N. Z. Nyazema 2006 Antibacterial activities of medicinal plants used for the treatment of diarrhoea in Limpopo Province, South Africa. Journal of Ethnopharmacology 105: 286-293.

Navaneethan, U. and R. A. Giannella 2011 Definition, Epidemiology, Pathophysiology, Clinical Classification, and Differential Diagnosis of Diarrhea. In Clinical Gastroenterology. G. Wu, ed. New York: Humana Press.

Nedkova, V., R. Komitova, V. Popova, H. Hitkova, Z. Mladenova and N. Korsun 2008 Diarrheal Etiology in Children Under Five in Bulgaria - A Prospective Study - Preliminary Results. 13th International Congress on Infectious Diseases Abstracts, Poster Presentations. e80: 15.044.

Nolan, J.

2001 Pursuing the Fruits of Knowledge: Cognitive Ethnobotany in Missouri's Little Dixie. Journal of Ethnobiology 21(2): 29-50.

Olson, D. M., E. Dinerstein, E. D. Wikramanaya, N. D. Burgess, G. V. N. Powell, E. C. Underwood, J. A. D’Amico, I. Itoua, H. E. Strand, J. C. Morrison, C. J. Loucks, T. F. Allnutt, T. H. Ricketts, Y. Kura, J. F. Lamoreux, W. W. Wettengel, P. Hedao and K. R. Kassem

2001 Terrestrial Ecoregions of the World: A New Map of Life on Earth. BioScience 51(11): 933-938.

Özgökçe, F. and H. Özçelik

2004 Ethnobotanical aspects of some taxa in East Anatolia, Turkey. Economic Botany 58: 697-704. 
PCD (The Partnership of Child Development)

2000 What's new in health \& nutrition of the school-age child and in school health and nutrition programmes? Partnership of Child Development: 1-46.

Peel, M. C., B. L. Finlayson and T. A. McMahon 2007 Updated World Map of the Köppen-Geiger Climate Classification. Hydrology and Earth System Sciences 11: 1633-1644.

Quinlan, M. B.

2010 Ethnomedicine and ethnobotany of fright, a Caribbean culture-bound psychiatric syndrome. Journal of Ethnobiology and Ethnomedicine 6: 1-18.

Sezik, E., M., Tabata, E. Yeşilada, G. Honda, K. Goto and Y. Ikeshiro 1991 Traditional medicine in Turkey I. Folk medicine in North-east Anatolia. Journal of Ethnopharmacology 35: 191-196.

Sezik, E., E. Yeşilada, G. Honda, Y. Takaishi, Y. Takeda and T.Tanaka 2001 Traditional medicine in Turkey X. Folk medicine in Central Anatolia. Journal of Ethnopharmacology 75: 95-115.

Sezik, E., E. Yeşilada, M. Tabata, G. Honda, Y. Takaishi and T. Fujita 1997 Traditional medicine in Turkey VIII. Folk medicine east Anatolia. Economic Botany 51: 195-211.

Sezik, E., M. Zor and E. Yeşilada 1992 Traditional medicine in Turkey II. Folk medicine in Kastamonu. International Journal of Pharmacognosy 30: 233-239.

Simeon, D. T. and S. Grantham-McGregor 1990 Nutritional deficiencies and children behaviour and mental development. Nutritional Research Review 3: 1-24.

Simsek, I., F. Aytekin, E. Yeşilada and Ş Yildirimli 2004 An ethnobotanical survey of the Beypazar1, Ayas, and Güdül district towns of Ankara Province (Turkey). Economic Botany 58: 795-720.

Stevens, P. F.

2001 onwards Angiosperm Phylogeny Website. St. Louis, MO: Missouri Botanical Garden. Version 9, June 2008. http://www.mobot.org/MOBOT/ research/APweb/. 
Tabata, M., G. Honda and E. Sezik

1988 A Report on Traditional and Medicinal Plants in Turkey (1986). Kyoto and Ankara: Faculty of Pharmaceutical Sciences, Kyoto University.

Tabata, M., E. Sezik, G. Honda, E. Yeşilada, K. Goto and Y. Ikeshiro 1994 Traditional medicine in Turkey III. Folk medicine in east Anatolia; Van and Bitlis Provinces. International Journal of Pharmacognosy 32: 3-12.

Tetali, P., C. Waghchaure, P. G. Daswani, N. H. Antia and T. J. Birdi 2009 Ethnobotanical Survey of Antidiarrhoeal Plants of Parinche Valley, Pune District, Maharashtra, India. Journal of Ethnopharmacology 123: 229-236.

The Ministry of Health of Turkey 2004 Turkey Health Report. Ankara: The Ministry of Health of Turkey (Türkiye Cumhuriyeti Sağlık Bakanlığı) and The School of Public Health (Refik Saydam Hıfzıssıhha Mektebi Müdürlüğü).

Turkish Ministry of the Interior 2010 Address based population registration system population census results, 2009. Turkish Statistical Institute, Prime Ministry (Türkiye Cumhuriyeti İçişleri Bakanlığ1): http://www.turkstat.gov.tr/PreHaberBultenleri.do?id=6178, Accessed February 15, 2011.

Tuzlac1, E. and P. Aymaz

2001 Turkish folk medicinal plants, Part IV: Gönen (Balıkesir). Fitoterapia 72: 323-343.

Tuzlac1, E. and E. Tolon 2000 Turkish folk medicinal plants, part III: Sile (Istanbul). Fitoterapia 71: 673685.

Ulukanlı̆̆ıl, M. and A. Seyrek 2004 Anthropometric status, anaemia and intestinal helminthic infections in shantytown and apartment schoolchildren in the Sanliurfa province of Turkey. European Journal of Clinical Nutrition 58: 1056-1061.

WHO and UNICEF

2004 Clinical Management of Acute Diarrhoea. WHO/FCH/CAH/04.7. Geneva: World Health Organization and United Nations' Children's Fund. 
Yeşilada, E., G. Honda, E. Sezik, M. Tabata, T. Fujita and T. Tanaka 1995 Traditional Medicine in Turkey. V. Folk Medicine in the Inner Taurus Mountains. Journal of Ethnopharmacology 46: 133-152.

Yeşilada, E., G. Honda, E. Sezik, M. Tabata, K. Goto and Y. Ikeshiro 1993 Traditional medicine in Turkey IV. Folk medicine in the Mediterranean subdivision. Journal of Ethnopharmacology 39: 31-38.

Yeşilada, E., E. Sezik, G. Honda, Y. Takaishi, Y. Takeda and T. Tanaka 1999 Traditional medicine in Turkey IX: Folk medicine in north-west Anatolia. Journal of Ethnopharmacology 64: 195-210.

Zhang, Y. 2008 Encyclopedia of Global Health. Los Angeles, CA: SAGE Publications. 


\title{
Chapter III
}

\section{COMPARATIVE IN-VITRO BACTERICIDAL AND BACTERIOSTATIC ACTIVITY OF ANTI-DIARRHEAL PLANTS OF CENTRAL ANATOLIA}

\begin{abstract}
In vitro bactericidal and bacteriostatic properties of methanol and aqueous extracts of 15 anti-diarrheal plants used in Central Anatolia were evaluated against 10 diarrhea-causing bacteria. Gram negative Escherichia coli, Pseudomonas aeruginosa, Klebsiella pneumoniae, Salmonella enteriditis, Shigella dysenteriae, and Vibrio cholerae, as well as Gram positive Staphylococcus aureus, Enterococcus faecalis, Bacillus cereus, and B. subtilis were used in a microdilution broth bioassay. Clinical and Laboratory Standards Institute (CLSI) protocols were used to determine percent inhibition and minimum inhibition concentrations (MICs). Minimum bacteriostatic inhibition concentrations (MBSs) and minimum bactericidal concentrations (MBCs) were determined as $\mu \mathrm{g} / \mathrm{mL}$. The MBCs were defined as the concentration at which bacteria ceased to grow and were no longer viable. The MBSs were further counted as colony forming units $(\mathrm{CFU}) / \mathrm{mL}$ and were defined as extract concentrations that disrupted macroscopic growth but did not kill the bacteria. Ninety-five MICs were $64 \mu \mathrm{g} / \mathrm{mL}$ or less, with $21 \mathrm{MICs}$ at $32 \mu \mathrm{g} / \mathrm{mL}$ or less. Vibrio cholerae, Staphylococcus aureus, and Enterococcus faecalis showed the most susceptibility to plant extracts, particularly those of Rosa canina, Cydonia oblonga, Hypericum perforatum, Rhus coriaria, and Rumex patientia. In summary, nine antidiarrheal plants from Central Anatolia had bacteriostatic activity against bacterial strains that cause acute gastrointestinal illness.
\end{abstract}




\section{INTRODUCTION}

Acute gastrointestinal disease (or diarrhea) is a significant threat to children under the age of five throughout the world. At least 2 million people die each year from diarrhea, and $90 \%$ of these deaths are children under the age of five (WHO 2009). Finding a prevention or treatment that is accessible and affordable to rural populations could alleviate some of these deaths.

Acute gastrointestinal disease is a significant problem for children in rural and peri-urban sites in Turkey (The Ministry of Health of Turkey 2004). Turkish WHO and government organizations promote Oral Rehydration Therapy (ORT) to treat diarrhea. While ORT decreases mortality, it alleviates symptoms of diarrhea and not their causes. Ineffectual therapies lead to chronic malnutrition, lowered school performance, and death (Ulukanlığgl and Seyrek, 2004). Moreover, ORT does not decrease morbidity, with children averaging 3.2 cases of diarrhea per year (Parashar, et al. 2003).

Diarrhea often is treated in homes with infusions or decoctions of wild or cultivated plants. A review of the Turkish ethnobotanical literature identified 91 species of plants from 35 families used to treat diarrhea (Chapter II). The present study identified 35 anti-diarrheal plant species from 20 families that are used in Central Anatolia, a semiarid steppe region in the center of the country. Of these species, 15 were evaluated for their anti-bacterial properties. These were selected on the basis of their availability, their flowering and fruiting seasons, and whether previous research had been conducted on their antibacterial properties. Because these plants were ingested regularly by locals, their toxicity was thought to be negligible by ethnopharmacologists (Sezik, et al., 2001). Later evaluation with an Alamar Blue Cytotoxicity Assay (Chapter IV) tested these assumptions. 
Pathogens that commonly cause diarrhea in Turkey are not databased, but 10 used in this study were chosen because they are: 1) common gut flora that can become pathogenic under certain conditions (E.coli, Klebsiella pneumoniae), 2) severe infectious agents (Vibrio cholerae, Shigella dysenteriae) which cause epidemics with high mortality rates, 3) difficult pathogens to treat because of innate and acquired antibiotic resistance (Enterococcus faecalis, Staphylococcus aureus, Pseudomonas aeruginosa), 4) common causes of food poisoning (Salmonella enterica, Bacillus cereus), and 5) common soil pathogens (B. subtilis). All are capable of toxifying or infecting the GI tract, albeit in different ways, and bringing on diarrhea and other complications.

Here, the antibacterial properties of each plant extract are evaluated against 10 diarrhea-causing bacteria. The primary questions addressed are: Do crude extracts from anti-diarrheal plants of Turkish villages exhibit bacteriostatic activity against bacteria strains that commonly cause diarrhea? Do crude extracts from anti-diarrheal plants of Turkish villages exhibit bactericidal activity against bacteria strains that commonly cause diarrhea? Does the activity of methanolic extracts differ from that of aqueous extracts (that are analogous to traditional preparations)? I tested the following hypotheses: H1. each Central Anatolian anti-diarrheal plant is bacteriostatic against each bacterial strain, and H2. each Central Anatolian anti-diarrheal plant is bactericidal against each bacterial strain.

\section{METHODS}

\section{Plant materials}

I collected the 15 plants in this study in their flowering and fruiting seasons between March and July in 2009. Determinations and names follow the Flora of Turkey (Davis, 1965, Güner, et al. 2001). Experts in the Botany Department at Gazi University 
assisted in plant identification when necessary. The Angiosperm Phylogeny Group III (2009, Stevens 2001 onwards) was used for familial nomenclature. Voucher specimens for all species were deposited in GAZI. Botanical data for the tested plants are included in Table 3.1.

Table 3.1 Codes used for methanol and aqueous extracts.

Two parts $\left({ }^{1},{ }^{2}\right)$ used for RP and RoC.

\begin{tabular}{|c|c|c|c|c|}
\hline Code & Latin Name & Family & Local Name & Parts used \\
\hline $\mathbf{A M}$ & Achillea millefolium L. & Asteraceae & $\begin{array}{l}\text { Amelotu, } \\
\text { Ayvadene }\end{array}$ & Herb \\
\hline $\mathrm{AC}$ & $\begin{array}{l}\text { Ajuga chamaepitys (L.) Schreb. subsp. } \\
\text { laevigata (Banks \& Sol.) P.H.Davis }\end{array}$ & Lamiaceae & Kiraçotu & Herb \\
\hline $\mathrm{CO}$ & Cydonia oblonga Mill. & Rosaceae & Ayva & Leaves \\
\hline HP & Hypericum perforatum L. & Hypericaceae & Sarı kantoron & Aerial Parts \\
\hline ML & Mentha longifolia Huds. & Lamiaceae & Yarpuz & Herb \\
\hline PR & Papaver rhoeas L. & Papaveraceae & Gelincik & Aerial Parts \\
\hline $\mathbf{R h C}$ & Rhus coriaria L. & Anacardiaceae & Sumak, somak & Fruits \\
\hline RoC & Rosa canina $\mathrm{L}$. & Rosaceae & Kuşburnu & Fruits $^{1}$, Galls $^{2}$ \\
\hline $\mathbf{R P}$ & Rumex patientia $\mathrm{L}$. & Polygonaceae & Enikmancar & Leaves $^{1}$, Fruits $^{2}$ \\
\hline TF & Tussilago farfara $\mathrm{L}$. & Asteraceae & Derekabalağ1 & Leaves \\
\hline TP & Teucrium polium $\mathrm{L}$. & Lamiaceae & $\begin{array}{l}\text { Acı yavşan, } \\
\text { Oğlanotu }\end{array}$ & Herb \\
\hline TT & Tribulus terrestris L. & Zygophyllaceae & Dadaşotu & Herb \\
\hline UD & Urtica dioica $\mathrm{L}$. & Urticaceae & Isırgan & Leaves \\
\hline VAA & Viscum album $\mathrm{L}$. & Santalaceae & Güveltekotu & Herb \\
\hline VAC & Vitex agnus-castus L. & Lamiaceae & Ayit & Fruits \\
\hline
\end{tabular}

From various field sites, I collected bulk samples (over 100g dry weight) and recorded habitat information, including GPS coordinates. I left a few plants in village areas for future populations and local use, but I collected multiple individuals for each species. To prevent cross-contamination, I isolated plant materials from dirt and kept plant species separated. Bulk materials were divided into ethnobotanically-relevant parts (leaves, stems, flowers, herbs) and dried in the open, in the lab for 48-72 hours. After drying, plant materials were stored in large plastic bags in an acquisitions storage unit in the Pharmaceuticals building at Gazi University. 
Before extraction, I pulverized dried plant samples with a mortar and pestle. Methanolic extracts of all plant samples were made by soaking $1 \mathrm{~g}$ plant material in $20 \mathrm{ml}$ methanol for $72 \mathrm{hrs}$, with daily agitation. To mimic traditional preparations, I prepared aqueous extracts by infusion (distilled water and plant material held at $80^{\circ} \mathrm{C}$ for $20 \mathrm{~min}$ ) at the ratio of $1 \mathrm{~g}$ plant material to $15 \mathrm{~mL}$ distilled water.

Methanolic extracts were vacuum filtered (Weißband 0.00007gr, Carl Schleicher \& Schüll no18089) and rotary-evaporated (Büchni Rotovapor R-200). Extracts were further dried in a sealed vacuum desiccant dome. Aqueous extracts were filtered, frozen at $-70^{\circ} \mathrm{C}$ and lyophilized (Lyolab C, LSL SecFroid). Main stocks of all extracts were stored in glass vials at $4^{\circ} \mathrm{C}$ in the Gazi University Pharmacognosy Laboratory. Extracts were re-constituted at $1 \mathrm{mg}$ dried extract to $1 \mathrm{~mL}$ excipient. Dimethylsulphoxide (DMSO) was used as the vehicle for methanolic extracts, and $\mathrm{H}_{2} \mathrm{O}$ for aqueous extracts. The stocks were sterile-filtered using $0.22 \mu \mathrm{m}$ Millipore filters (MA 01730, USA), and were stored in the dark at $4^{\circ} \mathrm{C}$.

\section{Materials Preparation}

Sterilized plant extracts (1-34) were concentrated at $1024 \mu \mathrm{g} / \mathrm{ml}$ for use in the microdilution assay. Stock solutions of reference antibiotics were prepared in solvents according to the CLSI (Barry, et al. 1999). Anti-bacterial controls (ampicillin, ciprofloxacin, gentamicin, nitrofurantoin, azithromicin, vancomycin, and trimethoprimsulfamethoxazole) were dissolved in phosphate buffer solution (ampicillin, nitrofurantoin, $\mathrm{pH}: 8.0 ; 0.1 \mathrm{~mol} \mathrm{~mL}$ ), in water (gentamicin, ciprofloxacin, vancomycin, trimethoprimsulfamethoxazole), or in 95\% ethanol and medium (azithromicin). 


\section{Bacterial Assay}

Bacterial strains (Table 3.2) belonged to the American Type Culture Collections (ATCC), the Culture Collection of the Refik Saydam Central Hygiene Institute (RSKK), and the NRRL, now the USDA Agricultural Research Service (ARS). Mueller Hinton Broth (MHB, Difco) and Mueller Hinton Agar (MHA, Oxoid) were used for growing and diluting the bacteria suspensions (Özçelik et al. 2005). The microorganism suspensions used for inoculation were prepared at $5 \times 10^{5} \mathrm{CFU} / \mathrm{ml}$ by determining the McFarland 0.5 turbidity $\left(1.5 \times 10^{8} \mathrm{CFU} / \mathrm{ml}\right)$ and diluting. Bacteria were in log phase of growth at the time of preparation.

Table 3.2 Bacterial Strains and Brief Descriptions

\begin{tabular}{|r|l|l|l|}
\hline 1 & Escherichia coli & ATCC 35218 & - Rod, motile \\
\hline 2 & Pseudomonas aeruginosa & ATCC 10145 & - Rod, unipolar motility \\
\hline 3 & Klebsiella pneumoniae & RSKK 574 & - Rod, non-motile, encapsulated \\
\hline 4 & Salmonella enteriditis & RSKK 538 & - Rod, motile \\
\hline 5 & Shigella dysenteriae & RSKK 851 & - Rod, non-motile \\
\hline 6 & Vibrio cholerae & RSKK 96023 & - Comma, polar flagellum \\
\hline 7 & Staphylococcus aureus & ATCC 25923 & + Clustered Coccus, non-motile \\
\hline 8 & Enterococcus faecalis & ATCC 29212 & + 2-Coccus, non-motile \\
\hline 9 & Bacillus cereus & NRRL B3711 & + Rod, Endospore \\
\hline 10 & Bacillus subtilis & ATCC 6633 & + Rod, Endospore \\
\hline
\end{tabular}

In a clear 96-well plate, each well was filled with Mueller-Hinton broth. Extract solutions were added to the first row to make a final concentration of $512 \mu \mathrm{g} / \mathrm{ml}$. Then I serially diluted the extracts across the remainder of the plate to constitute a range of concentrations from $512 \mu \mathrm{g} / \mathrm{ml}$ to $0.25 \mu \mathrm{g} / \mathrm{ml}$. Control wells were included for positive growth, negative growth, vehicle influence, and sterility of media. Wells were inoculated with $10 \mu 1$ of appropriate bacterial suspensions. All organisms, controls, and extracts were tested in triplicate. The 96 -well plates were incubated at $35^{\circ} \mathrm{C}$ overnight. The lowest 
concentration (MIC) of the extracts that completely inhibited visible, macroscopic growth was determined, as described in Özçelik, et al. (2008). When no growth was observed in a well, $10 \mu \mathrm{l}$ of the well contents were transferred onto an agar plate. When macroscopic growth was not observed in liquid medium but growth was seen on agar plates, I recorded the concentration as bacteriostatic. Viable cells counts were determined as CFU/ml. The effect was deemed bactericidal when growth was observed in neither the broth nor the agar plate.

\section{RESULTS}

Twenty different extracts had MBSs of $32 \mu \mathrm{g} / \mathrm{ml}$ or less (Table 3.3). Bactericidal concentrations (MBCs) were high $(512-256 \mu \mathrm{g} / \mathrm{ml})$ in most cases. The $R$. canina methanolic gall extract was bactericidal at $128 \mu \mathrm{g} / \mathrm{ml}$ and bacteriostatic at $16 \mu \mathrm{g} / \mathrm{ml}$. In this instance, the CFU was reduced to $9.0 \times 10^{3}$, an order of magnitude less than the initial $5.0 \times 10^{5}$ concentration of bacterial cells.

Table 3.3 Extracts with MBSs of $32 \mu \mathrm{g} / \mathrm{ml}$ or less and the inhibited bacteria

\begin{tabular}{|l|l|l|r|r|r|}
\hline Bacterium & Plant Name & Solvent & MBC & MBS & CFU/ml \\
\hline V. cholerae & Rosa canina-galls & Methanol & 128 & 16 & $9.0 \times 10^{3}$ \\
\hline S. aureus & Ajuga chamaepitys & Methanol & 512 & 32 & $2.4 \times 10^{4}$ \\
\hline S. aureus & Cydonia oblonga & Methanol & 512 & 4 & $1.6 \times 10^{4}$ \\
\hline S. aureus & Cydonia oblonga & Aqueous & 512 & 8 & $3.5 \times 10^{4}$ \\
\hline S. aureus & Hypericum perforatum & Methanol & 512 & 16 & $2.7 \times 10^{4}$ \\
\hline S. aureus & Hypericum perforatum & Aqueous & 512 & 8 & $3.7 \times 10^{4}$ \\
\hline S. aureus & Rhus coriaria & Methanol & $>512$ & 8 & $1.1 \times 10^{4}$ \\
\hline S. aureus & Rosa canina-galls & Methanol & $>512$ & 16 & $2.4 \times 10^{4}$ \\
\hline S. aureus & Rosa canina-galls & Aqueous & $>512$ & 4 & $3.9 \times 10^{4}$ \\
\hline S. aureus & Rumex patientia-fruit & Methanol & $>512$ & 8 & $2.4 \times 10^{4}$ \\
\hline S. aureus & Rumex patientia-fruit & Aqueous & $>512$ & 32 & $3.1 \times 10^{4}$ \\
\hline E. faecalis & Teucrium polium & Methanol & 256 & 32 & $3.6 \times 10^{4}$ \\
\hline
\end{tabular}




\begin{tabular}{|l|l|l|r|r|r|} 
E. faecalis & Teucrium polium & Aqueous & 256 & 32 & $1.8 \times 10^{4}$ \\
\hline E. faecalis & Tribulus terrestris & Methanol & 256 & 32 & $1.8 \times 10^{4}$ \\
\hline E. faecalis & Tribulus terrestris & Aqueous & 256 & 32 & $1.7 \times 10^{4}$ \\
\hline E. faecalis & Urtica dioica & Methanol & 256 & 32 & $1.9 \times 10^{4}$ \\
\hline E. faecalis & Urtica dioica & Aqueous & 256 & 32 & $3.3 \times 10^{4}$ \\
\hline E. faecalis & Viscum album & Methanol & 256 & 32 & $2.8 \times 10^{4}$ \\
\hline E. faecalis & Viscum album & Aqueous & 256 & 32 & $3.9 \times 10^{4}$ \\
\hline E. faecalis & Vitex agnus-castus & Methanol & 256 & 32 & $3.5 \times 10^{4}$ \\
\hline E. faecalis & Vitex agnus-castus & Aqueous & 256 & 32 & $2.0 \times 10^{4}$ \\
\hline
\end{tabular}

V. cholerae $=$ Vibrio cholerae $;$ S. aureus $=$ Staphylococcus aureus $;$ E. faecalis=Enterococcus faecalis

Methanolic and aqueous extracts of Teucrium polium, Tribulus terrestris, Urtica dioica, Viscum album, and Vitex agnus-castus inhibited Enterococcus faecalis at MBSs of $32 \mu \mathrm{g} / \mathrm{ml}$ and MBCs at $256 \mu \mathrm{g} / \mathrm{ml}$, with a decrease in CFUs. Six plants inhibited S. aureus at MBSs ranging from $4 \mu \mathrm{g} / \mathrm{ml}$ to $64 \mu \mathrm{g} / \mathrm{ml}$ (Table 3.4). Cydonia oblonga methanolic leaf extract was bacteriostatic at $4 \mu \mathrm{g} / \mathrm{ml}$ against $S$. aureus, while the aqueous extract was bacteriostatic at $8 \mu \mathrm{g} / \mathrm{ml}$ against $S$. aureus. These MBSs are at clinically relevant concentrations, similar to pharmaceutical drug concentrations.

Table 3.4 MICs $(\mu \mathrm{g} / \mathrm{ml})$ of six extracts against Staphylococcus aureus

\begin{tabular}{|l|l|l|l|l|l|l|}
\cline { 2 - 7 } & $\begin{array}{l}\text { Rumex } \\
\text { patientia }\end{array}$ & $\begin{array}{l}\text { Rosa } \\
\text { canina }\end{array}$ & $\begin{array}{l}\text { Rhus } \\
\text { coriaria }\end{array}$ & $\begin{array}{l}\text { Hypericum } \\
\text { perforatum }\end{array}$ & $\begin{array}{l}\text { Cydonia } \\
\text { oblonga }\end{array}$ & $\begin{array}{l}\text { Ajuga } \\
\text { chamaepitys }\end{array}$ \\
\cline { 2 - 8 } & Fruits & Galls & Fruits & Herb & Leaves & Herb \\
\hline Aqueous & 32 & 4 & 16 & 8 & 8 & 64 \\
\hline Methanolic & 8 & 16 & 8 & 16 & 4 & 32 \\
\hline
\end{tabular}

Rhus coriaria fruit extracts inhibited S. aureus at $8 \mu \mathrm{g} / \mathrm{ml}$ in methanolic extract and $16 \mu \mathrm{g} / \mathrm{ml}$ in aqueous extract. The aqueous extract of Ajuga chamepitys inhibited S. aureus at $64 \mu \mathrm{g} / \mathrm{ml}$ and the methanolic extract inhibited S. aureus at $32 \mu \mathrm{g} / \mathrm{ml}$. Galls of $R$. canina 
are effective against $S$. aureus and $V$. cholerae, and rosehips showed similar yet less potent activity. The methanolic extract of $R$. canina galls had MBS concentrations of $16 \mu \mathrm{g} / \mathrm{ml}$ and $\mathrm{MBC}$ concentrations at $128 \mu \mathrm{g} / \mathrm{ml}$ against $V$. cholerae (Table 3.5).

Table 3.5 MICs $(\mu \mathrm{g} / \mathrm{ml})$ of Rosa canina extracts against Vibrio cholerae

\begin{tabular}{|l|l|l|l|l|}
\cline { 2 - 6 } \multicolumn{1}{c|}{} & \multicolumn{2}{c|}{ Galls } & \multicolumn{2}{c|}{ Fruits } \\
\cline { 2 - 6 } \multicolumn{1}{c|}{} & Methanol & Aqueous & Methanol & Aqueous \\
\hline MBC & 128 & 512 & 512 & 512 \\
\hline MBS & 16 & 64 & 64 & 64 \\
\hline
\end{tabular}

Of the crude extracts tested in this study, $28 \%$ inhibited bacteria at or below $64 \mu \mathrm{g} / \mathrm{ml}$, and $6 \%$ inhibited bacteria at or below $32 \mu \mathrm{g} / \mathrm{ml}$. Nine plants (Rosa canina, Cydonia oblonga, Ajuga chamaepitys, Rhus coriaria, Rumex patientia, Teucrium polium, Tribulus terrestris, Urtica dioica, and Viscum album) are of further interest against $E$. coli, Vibrio cholerae, Staphylococcus aureus, and Enterococcus faecalis.

\section{DISCUSSION}

Phytochemicals that exhibit bacteriostatic instead of bactericidal properties can disrupt pathogenicity and halt disease without selecting for resistance in bacteria. In this study, the severe pathogen $V$. cholerae was inhibited by methanolic extracts of $R$. canina galls at MBSs of $16 \mu \mathrm{g} / \mathrm{ml}$ and MBCs of $128 \mu \mathrm{g} / \mathrm{ml}$. Enterococcus faecalis was inhibited by aqueous and methanolic extracts of T. polium, T. terrestris, U. dioica, V. album, and $V$. agnus-castus at MBSs of $32 \mu \mathrm{g} / \mathrm{ml}$ and MBCs of $256 \mu \mathrm{g} / \mathrm{ml}$. Enterococcus faecalis has several innate resistance factors for disrupting the efficacy of various antibiotics, including last-resort antibiotics such as vancomycin (Garrity 2004). It is a major concern in nosocomial settings, as is S.aureus, another bacteria with increasing antibiotic 
resistance. Methanolic extracts of $C$. oblonga and $R$. canina galls showed bacteriostatic activity at $4 \mu \mathrm{g} / \mathrm{ml}$, while bactericidal activity was not observed until extract concentrations reached $512 \mu \mathrm{g} / \mathrm{ml}$ or more (Table 3.3). The aqueous extracts of $C$. oblonga and $H$. perforatum had MBSs of $8 \mu \mathrm{g} / \mathrm{ml}$, as did the methanolic extracts of $R$. coriaria and $R$. patientia fruit. MBCs remained high, at or above $512 \mu \mathrm{g} / \mathrm{ml}$.

Cydonia oblonga, a member of Rosaceae, has high concentrations of pectins and polyphenolic compounds such as highly astringent hydrolyzable tannins. In Portugal, an HPLC analysis revealed high polyphenolic content of $C$. oblonga leaves (Oliveira, et al. 2007). Previous research has analyzed fruit pulp and peels of quince fruits for antibacterial activity, with acetone extracts of pulp showing inhibition of $S$. aureus in a disc diffusion assay (Fattouch, et al. 2007).

Several previous studies have analyzed $R$. coriaria spice for antibacterial properties against Bacillus, Listeria, E. coli, Salmonella, Staphylococcus, Shigella, Klebsiella, Branhamella, and Pseudomonas with varying effects (Fazeli, et al. 2007, Khalil, 1996, Sokmen, et al. 1999).

Ajuga chamaepitys is a plant endemic to eastern Turkey. No previous research on the antibacterial properties of $A$. chamaepitys was found in the published literature. Antiviral and antifungal properties of $A$. chamaepitys have been published (Orhan, et al. 2009), and research on the relief of colitis with the use of teupolioside, a phenylpropanoid glycoside harvested from $A$. reptans, was shown to slow intestinal motility and fecal transit (DiPaola, et al. 2009).

Many species of Lamiaceae are used in circum-Mediterranean regions. Researchers analyzed synergistic capabilities of $T$. polium with various pharmaceutical antibiotics against $S$. aureus (Darwish, et al. 2002) and P. aeruginosa (Aburjai, et al. 
2001). Ethyl acetate extracts of the leaves of V. agnus-castus inhibited methicillinresistant Staphylococcus aureus, carbapenem-resistant Acinetobacter spp., and Enterobacteriaceae species at $0.312,0.625$, and $0.625 \mathrm{mg} / \mathrm{ml}$ respectfully (Arokiyaraj, et al. 2009). Menthol isolated from M. longifolia leaves in Iraq inhibited S. aureus and $S$. mutans at $15.6 \mu \mathrm{g} / \mathrm{ml}$ and S. faecalis, S. pyogenis, and L. acidophilus at $31.2 \mu \mathrm{g} / \mathrm{ml}$ (AlBayati 2009). In the current study, M. longifolia had MICs of $128 \mu \mathrm{g} / \mathrm{ml}$ or above, but $T$. polium and $V$. agnus-castus inhibited E. faecalis at $32 \mu \mathrm{g} / \mathrm{ml}$.

A second important plant family in this region is the Asteraceae. In this study, Achillea millefolium and Tussilago farfara were evaluated. In Siberia, where T. farfara is used as an antiseptic and antiphlogistic, ethanolic extracts of T. farfara had an MIC of $62.50 \mathrm{mg} / \mathrm{ml}$ against $S$. aureus (Kokoska, et al. 2002). Achillea millefolium exhibited antibacterial activity at high concentrations, but the essential oils were found to be more active than aqueous or methanolic extracts (Stojanovic, et al. 2005). In some villages in Turkey, A. millefolium is known as amelotu or "the deed weed," which refers to the vernacular term for diarrhea, amel ("the deed").

While several studies have analyzed rosehips for antioxidant properties, only one previous publication was found evaluating antibacterial activities. Rosa canina seeds from Scotland were shown to inhibit E. coli at $0.10 \mathrm{mg} / \mathrm{ml}$ (Yashodharan, et al. 2002).

Other plants commonly used to treat diarrhea include the rind of Punica granatum, Sorbus domesticus, and other Rosaceae species as well as Cornus mas L. (Cornaceae). The ripe fruits of these plants were not available for collection at the time of study. Plants in the Rosaceae are known for their astringency, which affects the mucosal lining of the gut and tightness of cell junctions. Mucus is a critical attachment and nourishment factor for the pathogenicity of many gastrointestinitis-inducing bacteria. Rosaceous fruits also 
often contain pectin, which adds bulk to the intestinal contents and facilitates proper muscle movement. Pectins and astringent coumpounds are known to affect the human gut and treat symptoms of diarrhea (Lewis and Elvin-Lewis 2003).

\section{CONCLUSION}

Results showed $95 \mathrm{MBSs}$ at $64 \mu \mathrm{g} / \mathrm{ml}$ or below. Twenty-one MBSs were read at $32 \mu \mathrm{g} / \mathrm{ml}$ or less, yet their MBCs were much higher, at $256 \mu \mathrm{g} / \mathrm{ml}$ or more. Thus, plant extracts were inhibiting bacterial growth without killing the bacteria. Such bacteriostatic

effects are desirable in novel treatments against bacteria. Since bacteria are only inhibited in bacteriostatc circumstances and not killed, resistant strains evolve much less rapidly.

Of the clinically relevant MICs, with MBSs of $32 \mu \mathrm{g} / \mathrm{ml}$ or less, nine of the extracts were aqueous while 12 were methanolic. Since traditional uses of plants usually prescribe aqueous preparations, the relatively high effectiveness of aqueous extracts in this study supports the continued use of these plants and their reliability in treating infectious diarrhea.

Of special significance, the galls from the $R$. canina showed low MICs against 6 of the 10 bacteria. Galls form from a complex interaction between an insect, in this case, and a host plant part. The novel up-/down-regulation of genes in this process could lead to a change in anabolic pathways or new chemicals.

This study included only 15 of the 35 non-domesticated plant species collected in Central Anatolia. Throughout Turkey, 91 plant species were recorded as medicinal for diarrhea. Further research for biologically active chemical constituents, cytotoxicity levels, and mechanisms of action could lead to a readily-available treatment for acute gastroenteritis in the region. 


\section{ACKNOWLEDGMENTS}

A scholarship for research abroad was awarded to Rose by the Turkish Fulbright Commission and the USDS. Gazi University was the sponsoring insitution in Ankara, Turkey, with collaborative efforts in the Pharmaceutical Department. Special thanks to the villagers who participated.

There were no financial or commercial conflicts of interest.

\section{REFERENCES}

Aburjai T, Darwish RM, Al-Khalil S, Mahafzah A, Al-Abbadi A. 2001. Screening of antibiotic resistance inhibitors from local plant materials against two different strains of Pseudomonas aeruginosa. J Ethnopharmacol 76: 39-44.

Al-Bayati FA. 2009. Isolation and identification of antimicrobial compound from Mentha longifolia L. leaves grown wild in Iraq. Ann Clin Microbiol Antimicrob 8: 20-25.

APG III. 2009. An update of the Angiosperm Phylogeny Group classification for the orders and families of flowering plants: APG III. Botan J Linn Soc 161: 105-121.

Arokiyaraj S, Perinbam K, Agastian P, Kumar RM. 2009. Phytochemical analysis and antibacterial activity of Vitex agnus-castus. Int J Green Pharmacy 3: 162-164.

Barry A, Craig W, Nadler N, Reller LB, Sanders C, Swenson J. 1999. M26-A, Methods for Determining Bactericidal Activity of Antimicrobial Agents; Approved Guideline. NCCLS Catalog, now the Clinical and Laboratory Standards Institute (CLSI). 19: 1-30.

Darwish R M, Aburjai T, Al-Khalil S, Mahafzah A. 2002. Screening of antibiotic resistant inhibitors from local plant material against two strains of Staphylococcus aureus. J Ethnopharmacol 79: 359-364.

Davis P. 1965. Flora of Turkey and the East Aegean Islands. Edinburgh University Press: Edinburgh.

DiPaola R, Esposito E, Mazzon E, Riccardi L, Caminiti R, Dal Toso R, Pressi G, Cuzzocrea S. 2009. Teupolioside, a phenylpropanoid glycosides of Ajuga reptans 
biotechnologically produced by IRBN22 plant cell line, exerts beneficial effects on a rodent model of colitis. Biochem Pharmacol 77: 845-857.

Fattouch S, Caboni P, Coroneo V, Tuberoso CIG, Angioni A, Dessi S, Marzouki N, Cabras P. 2007. Antimicrobial activity of Tunisian quince (Cydonia oblonga Miller) pulp and peel polyphenolic extracts. J Agricult Food Chem 55: 963-969.

Fazeli M, Amin G, Attari M, Ashtiani H, Jamalifar H, Samadi N. 2007. Antimicrobial activities of Iranian sumac and avishan-e shirazi (Zataria multiflora) against some foodborne bacteria. Food Control 18: 646-649.

Garrity GM. 2004. Bergey's Manual of Systematic Bacteriology. Springer: New York.

Güner, et al. 2001 Flora of Turkey and the East Aegean Islands (vol 11). Edinburgh University Press: Edinburgh.

Khalil M. 1996. Antimicrobial properties of Rhus coriaria seeds (Sumach). J King Saudi Uni 8(2): 257-267.

Kokoska L, Polesny Z, Rada V, Nepovim A, Vanek T. 2002. Screening of some Siberian medicinal plants for antimicrobial activity. $J$ Ethnopharmacol 82(1): 51-53.

Lewis W, Elvin-Lewis M. 2003. Medical Botany: Plants Affecting Human Health. Wiley \& Sons, Inc.: Hoboken, NJ.

Oliveira A, Pereira J, Andrade P, Valentão P, Seabra R, Silva B. 2007. Phenolic profile of Cydonia oblonga Miller leaves. J Agricult Food Chem 55: 7926-7930.

Orhan I, Deliorman-Orhan D, Özçelik B. 2009. Antiviral activity and cytotoxicity of the lipophilic extracts of various edible plants and their fatty acids. Food Chem 115: 701-705.

Özçelik B, Deliorman-Orhan D, Karaoglu T, Ergun F. 2005. Antimicrobial activities of various Cirsium hypoleucum extracts. Ann Micro 55: 51-54.

Özçelik B, Deliorman-Orhan D, Özgen S, Ergün F. 2008. Antimicrobial activity of flavonoids against extended-spectrum ß-Lactamase (ESBL)-producing Klebsiella pneumoniae. Tropl J Pharmaceut Res 7: 1151-1157.

Parashar U, Bresee J, Glass R. 2003. The global burden of diarrhoeal disease in children. Bull WHO 8: 236. 
Sezik E, Yeşilada E, Honda G,Takaishi Y, Takeda Y, Tanaka T. 2001 Traditional medicine in Turkey X. Folk medicine in Central Anatolia. $J$ Ethnopharmacol 75: 95-115.

Sokmen A, Jones B, Erturk M. 1999. The in vitro antibacterial activity of Turkish medicinal plants. $J$ Ethnopharmacol 67: 79-86.

Stevens PF. 2001 onwards. Angiosperm Phylogeny Website, Version 9. Missouri Botanical Gardens: June 2008; http://www.mobot.org/MOBOT/research/APweb/.

Stojanovic G, Radulovic N, Hashimoto T, Palic R. 2005. In vitro antimicrobial activity of extracts of four Achillea species: the composition of $A$. clavennae L. (Asteraceae) extract. J Ethnopharmacol 101: 185-190.

The Ministry of Health of Turkey. 2004. Turkey Health Report. The Ministry of Health of Turkey (Türkiye Cumhuriyeti Sağlık Bakanlığı) and The School of Public Health (Refik Saydam Hifzıssıhha Mektebi Müdürlüğü): Ankara.

Ulukanlığıl M, Seyrek A. 2004. Anthropometric status, anaemia and intestinal helminthic infections in shantytown and apartment schoolchildren in the Sanliurfa province of Turkey. Euro J Clin Nutr 58: 1056-1061.

WHO. 2009. Diarrhoeal Diseases. World Health Organization: Geneva. http://www.who.int/vaccine_research/diseases/diarrhoeal/en/index.html

Yashodharan K, Cox PJ, Jaspars M, Nahar L, Sarker SD. 2002. Screening seeds of Scottish plants for antibacterial activity. J Ethnopharmacol 83: 73-77. 


\title{
Chapter IV
}

\section{BACTERIAL INHIBITION AND CYTOTOXIC PROPERTIES OF PLANTS USED TO TREAT DIARRHEA}

\begin{abstract}
I evaluated 15 Central Anatolian plants for their safety and efficacy in inhibiting the growth of 21 bacterial strains that commonly infect the human intestinal tract and cause diarrhea. I carried out ethnobotanical research in Central Anatolia for one year, beginning in September 2008. Following interviews and a literature review, I collected plants used to treat diarrhea. Voucher specimens were deposited in Gazi University's Herbarium (GAZI). I collected plant materials and processed them in bulk, with methanolic and aqueous extracts prepared from medicinally-relevant parts of the plants for a total of 34 extracts. I used a microtiter broth dilution assay (CLSI protocol) to evaluate antibacterial activity and an Alamar Blue cytotoxicity assay to evaluate the cytotoxicity of the plants for human cells. The percent inhibition was used to calculate the effectiveness of the 34 extracts in inhibiting one or more of the 21 bacteria. Rosa canina, Hypericum perforatum, Vitex agnus-castus, and Rhus coriaria showed significant inhibition at low concentrations $(32,16,8$, and $4 \mu \mathrm{g} / \mathrm{ml}$ ) against 8 bacteria (Enterococcus faecalis, Klebsiella pneumoniae, Listeria monocytogenes, Pseudomonas aeruginosa, Staphylococcus aureus, Shigella flexneri, Vibrio parahaemolyticus, and Yersinia pseudotuberculosis). Further evaluation of these Turkish plants could lead to an easily accessible, readily available plant-based remedy for diarrhea in the region.
\end{abstract}




\section{INTRODUCTION}

Plants are commonly used to treat gastrointestinal problems and often are the first line of defense against diarrhea or gastroenteritis. Acute gastrointestinal disease (or diarrhea) is a major concern for children under the age of five in rural and peri-urban areas all over the world (WHO 2009). Bacteria cause 2 to 4 billion cases of infectious diarrhea every year, leading to 3 to 5 million deaths in developing countries (Sanchez and Holmgren 2005). Infectious diarrhea disproportionately affects residents of less affluent countries (Guerrant, et al. 2002).

In rural Turkey, diarrhea usually is treated in homes with infusions or decoctions of wild or cultivated plants (Chapter II). Turkish ethnobotanical literature lists 91 species of plants from 35 families that are used to treat diarrhea. Research conducted in this study recorded 35 plant species from 20 families that are used to treat diarrhea in Central Anatolia, a semiarid steppe region in Turkey (Peel, et al. 2007). Fifteen of these species are herein evaluated for their safety and anti-bacterial properties.

Previous research on anti-diarrheal plants generally focused on phytochemical properties to slow motility, decrease spasms, and increase water and electrolyte readsorption in the intestines (e.g., Palombo 2006). In addition to human physiological changes, plant compounds might interrupt the attachment of bacteria to intestinal epithelia or unfavorably alter microenvironments for pathogenic bacterial growth. Blocking or disrupting bacterial pathogenicity treats the cause of infectious diarrhea, not just the symptoms, and therefore decreases the severity of infection in a patient and prevents the spread of the infectious agent (Levine and Svennerholm 2008).

The aim of this study was to evaluate the anti-bacterial and cytotoxic properties of anti-diarrheal plants from Central Anatolia. The three primary questions addressed here 
are: Do crude extracts from plants that are used to treat diarrhea in rural Central Anatolia exhibit antibacterial activity against bacteria strains that commonly cause diarrhea? Do these plant extracts have acceptable levels of cytotoxicity and are therefore safe for human ingestion? Do the activities of aqueous and methanolic extracts of the same plant differ?

Four hypotheses were tested. H1. Each Central Anatolian anti-diarrheal plant inhibits each bacterial strain. H2. There is no difference in inhibitory concentration between more traditional aqueous extracts of a plant and methanolic extracts of the same plant. H3. Each Central Anatolian anti-diarrheal plant shows no toxicity to the cell lines used in the Alamar Blue Cytotoxicity Assay. H4. The combined inhibitory and toxicity data support the traditional use of Central Anatolian anti-diarrheal plants.

\section{METHODS}

\section{Plant Extract Preparation}

I prepared crude plant extracts from dried bulk plant specimens collected in Turkey during ethnobotanical field work (IRB Approval \#082508-01). Plants were identified by using the Flora of Turkey and the East Aegean Islands (Davis 1965, Güner, et al. 2001). I deposited vouchers in GAZI in Ankara, Turkey. Methanolic and aqueous extractions were made from medicinally-used parts of 15 plants, with two parts used in two plants and one part used in the remaining thirteen. In total, 34 crude extracts were screened in the cytotoxicity and anti-bacterial assays (Table 4.1). 
Table 4.1 Plant extracts listed with Codes, Local Names, Family Names, and Parts Used. Note that two plant parts $\left({ }^{1},{ }^{2}\right)$ were used for Rumex patientia and Rosa canina.

\begin{tabular}{|l|l|l|l|l|}
\hline Code & Latin Name & Family & Local Name & Parts used \\
\hline AM & Achillea millefolium L. & Asteraceae & $\begin{array}{l}\text { Amelotu, } \\
\text { Ayvadene }\end{array}$ & Herb \\
\hline AC & $\begin{array}{l}\text { Ajuga chamaepitys } \text { (L.) } \\
\text { Schreb. subsp. laevigata } \\
\text { (Banks \& Sol.) } \text { P.H.Davis }\end{array}$ & Lamiaceae & Kiraçotu & Herb \\
\hline CO & Cydonia oblonga Mill. & Rosaceae & Ayva & Leaves \\
\hline HP & Hypericum perforatum L. & Hypericaceae & Sarı kantoron & Aerial Parts \\
\hline ML & Mentha longifolia Huds. & Lamiaceae & Yarpuz & Herb \\
\hline PR & Papaver rhoeas L. & Papaveraceae & Gelincik & Aerial Parts \\
\hline RhC & Rhus coriaria L. & Anacardiaceae & Sumak, somak & Fruits \\
\hline RoC & Rosa canina L. & Rosaceae & Kuşburnu & Fruits ${ }^{1}$ Galls ${ }^{2}$ \\
\hline RP & Rumex patientia L. & Polygonaceae & Enikmancar & Leaves ${ }^{1}$ Fruits ${ }^{2}$ \\
\hline TF & Tussilago farfara L. & Asteraceae & Derekabalağ1 & Leaves \\
\hline TP & Teucrium polium L. & Lamiaceae & Ac1 yavşan, & Herb \\
& & & Oğlanotu, & \\
\hline TT & Tribulus terrestris L. & Zygophyllaceae & Dadaşotu & Herb \\
\hline UD & Urtica dioica L. & Urticaceae & Isirgan & Leaves \\
\hline VAA & Viscum album L. & Santalaceae & Güveltekotu & Herb \\
\hline VAC & Vitex agnus-castus L. & Lamiaceae & Ayıt & Fruits \\
\hline
\end{tabular}

I made methanolic extracts by soaking homogenized plant materials in methanol $(1 \mathrm{~g} / 20 \mathrm{ml})$ for $72 \mathrm{hr}$, with daily agitation. Analogous to traditional preparations, I prepared aqueous extracts by infusion (distilled water and plant material held at $80^{\circ} \mathrm{C}$ for 20 minutes) at the ratio of $1 \mathrm{~g}$ plant material to $15 \mathrm{ml}$ distilled water, so that plant materials were completely submerged during the procedure.

Methanolic extracts were vacuum-filtered (Weißband 0.00007gr, Carl Schleicher \& Schüll no18089), rotary-evaporated (Büchni Rotovapor R-200), and dried in a sealed vacuum desiccant dome. Aqueous extracts were filtered, frozen $\quad\left(-80^{\circ} \mathrm{C}\right)$ and lyophilized (Lyolab C LSL SecFroid). Main stocks of all extracts were stored in glass vials at -5 to $4^{\circ} \mathrm{C}$. I re-constituted dried plant extracts at $10 \mathrm{mg} / \mathrm{ml}$ in dimethylsulphoxide 
(DMSO) for methanol extracts and phosphate-buffered saline solution (PBS) for aqueous extracts. The final concentrations of DMSO and PBS solvents constituted less than $5 \%$ of total well volume, thereby preventing false positives. The re-constituted extracts were sterile-filtered (0.2 microns, Corning Incorporated 431222) and stored in amber glass vials at $-5^{\circ} \mathrm{C}$.

\section{Anti-Bacterial Assay}

Twenty-one bacteria strains (Table 4.2) were established on agar plates and grown in Cation-Adjusted Mueller Hinton Broth (CAMHB, Difco) at $37^{\circ} \mathrm{C}$ according to the Clinical Laboratory Standards Institute (CLSI) protocol M26-A (Barry, et al. 1999). Growth curves for each bacterial strain were determined by kinetic readings (every 10 $\min / 24$ hrs) on a BioTek Powerwave Spectrophotometer with incubator and shaker capabilities. Each strain was inoculated in log phase and analyzed at its peak log phase of growth.

A preliminary broth dilution assay (Amsterdam 1996, Isenberg 2004) was used to evaluate all 34 extracts and to determine the five that were most active. All extracts were serially diluted in a 96-well plate so that concentrations ranged from $512 \mu \mathrm{g} / \mathrm{ml}$ to $8 \mu \mathrm{g} / \mathrm{ml}$. Controls included positive and negative growth controls as well as DMSO and PBS solvent controls. The antibiotics ampicillin, ciprofloxacin, nitrofurantoin, azithromicin, and vancomycin were used as positive controls. 
Table 4.2 Bacteria strains listed with codes (abbreviations) and standards

\begin{tabular}{|l|l|l|l|}
\hline$\#$ & Code & Bacteria & Standard \\
\hline $\mathbf{1}$ & Bs-1 & Bacillus subtilis & ATCC 6051 \\
\hline $\mathbf{2}$ & Ec-0 & Escherichia coli & Nat OH5 alpha \\
\hline $\mathbf{3}$ & Ec-1 & Escherichia coli & ATCC 10836 \\
\hline $\mathbf{4}$ & Ef-1 & Enterococcus faecalis & ATCC 19433 \\
\hline $\mathbf{5}$ & Kp-1 & Klebsiella pneumoniae & ATCC BAA-1705 \\
\hline $\mathbf{6}$ & Lm-1 & Listeria monocytogenes & ATCC 19115 \\
\hline $\mathbf{7}$ & Lm-2 & Listeria monocytogenes & ATCC19015 \\
\hline $\mathbf{8}$ & Pa-1 & Pseudomonas aeruginosa & PA 01 \\
\hline $\mathbf{9}$ & Se-1 & Salmonella enterica & ATCC 14028 \\
\hline $\mathbf{1 0}$ & St-4 & Salmonella enterica typhimurium & Plano Lab, UM \\
\hline $\mathbf{1 1}$ & Sa-1 & Staphylococcus aureus & Mathee Lab, FIU \\
\hline $\mathbf{1 2}$ & Sa-2 & Staphylococcus aureus & ATCC 10882 \\
\hline $\mathbf{1 3}$ & Sa-3 & Staphylococcus aureus & ATCC 25923 \\
\hline $\mathbf{1 4}$ & Sa-4 & Staphyloccocus aureus & ATCC 29213 \\
\hline $\mathbf{1 5}$ & Sf-1 & Shigella flexneri (1a) & ATCC 9199 \\
\hline $\mathbf{1 6}$ & Ss-1 & Shigella sonnei & ATCC 25931 \\
\hline $\mathbf{1 7}$ & Ye-1 & Yersinia enterocolitica & 8081c w/o pYv \\
\hline $\mathbf{1 8}$ & Ye-2 & Yersinia enterocolitica & O18 8081v w/ pYv \\
\hline $\mathbf{1 9}$ & Yu-1 & Yersinia pseudotuberculosis & III YP KmR \\
\hline $\mathbf{2 0}$ & Yu-2 & Yersinia pseudotuberculosis & ATCC 6903 \\
\hline $\mathbf{2 1}$ & Vp-1 & Vibrio parahaemolyticus & ATCC 17802 \\
\hline
\end{tabular}

Bacteria were grown to log phase, concentrated to McFarland Standard 0.5 turbidity, and then diluted to $5 \times 10^{5}$ colony-forming units (CFU)/ml. Serial dilution colony counts were performed to evaluate bacterial concentrations. Assays were completed in triplicate. After incubation at $37^{\circ} \mathrm{C}$, plates were read for the absence or presence of macroscopic growth in wells at the peak of log growth for each strain and at 18 hours (or 24 hours for slow-growing Yersinia spp.).

After the preliminary screening, the five extracts that showed the most inhibition against the most bacteria were run through a second analysis involving kinetic optical density (OD) readings at 600nm wavelength (BioTek Powerwave Spectrophotometer). Readings were taken so that minor shifts in growth curves brought about by extracts could 
be analyzed. For instance, in Figure 4.1, Box A shows a normal growth curve, while Box B shows a growth curve of bacteria growing in the presence of a plant extract. More sensitive data were acquired by taking multiple readings and comparing bacterial growth at peak log phases instead of at one standard 18 or $24 \mathrm{hr}$ reading.

Figure 4.1 Differing growth curve patterns betwen Box A and Box B with optimal reading time at peak of logarithmic growth versus later at 18 or 24 hours

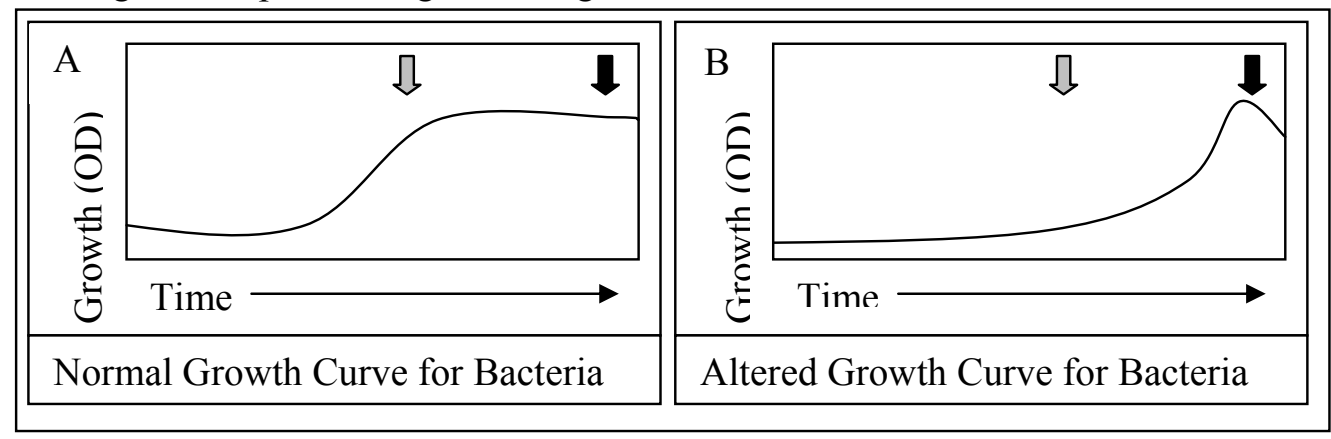

Kinetic OD readings were taken $(10 \mathrm{~min} / 24 \mathrm{hr})$ for the top five extracts and five antibiotic controls. The peaks of the bacterial growth control triplicates were averaged and used to calculate \% inhibition with the following formula (Quave, et al. 2008).

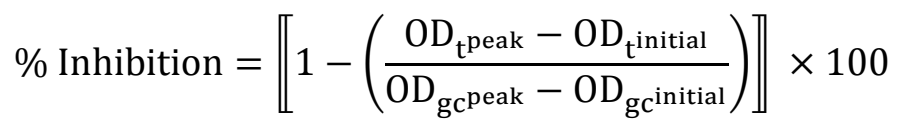

The difference in initial and log peak optical density (OD) readings of the treatment group were divided by the difference in initial and log peak OD readings of the growth control for that bacterial strain. The resulting number was then subtracted from one and multiplied by 100 to create a percentage.

The $\mathrm{MIC}_{50}\left(50 \%\right.$ of bacteria growth inhibited) and $\mathrm{MIC}_{90}(90 \%$ inhibited $)$ were then tabulated using the percent inhibitions of each extract. When $\mathrm{MIC}_{50}$ or $\mathrm{MIC}_{90}$ were 
at or below $64 \mu \mathrm{g} / \mathrm{ml}$, a one-way ANOVA with Tukey post-hoc tests was performed using PASW SPSS software to analyze the significant differences $(\mathrm{p}<0.05)$ in OD readings between concentrations of the extract for a specific bacterial strain.

\section{Cytotoxicity Assay}

I performed a cytotoxicity assay to evaluate the relative safety of the crude extracts by determining whether the extracts disrupt human cellular metabolism. The Alamar Blue Assay measures cellular metabolic activity in a time- and concentrationdependent manner. Unlike the MTT Assay, cells are kept alive and handling of cells and potential contamination is minimized (Gloeckner, et al. 2001). As a dye, Alamar Blue is conveniently stable, non-radioactive, and non-toxic. It is composed of the blue, nonfluorescent indicator resazurin which is naturally, continuously, and reversibly reduced by living cells to red, fluorescent resorufin (O'Brien, et al. 2000). The reduction can be measured quantitatively, with higher absorbance levels correlating with higher metabolic activity.

Human cell lines included prostate adenocarcinoma PC-3 (ATCC CRL-1435), skin melanoma SKMEL-5 (ATCC HTB-70), and hepatocellular carcinoma HEP G-2 (ATCC CRL-11997). Since the liver filters ingested materials such as phytochemicals, any inhibition of the HEP G-2 cell line was taken into special consideration.

I established the HEP G-2 cell line in Eagle's Medium (ATCC 30-2003) with 10\% Fetal Bovine Serum (Sigma-Aldrich F0926) and 1\% Antibiotic and Antimycotic Solution (100x, Sigma A 5955). The HEP G-2 cells grew to confluency in 4-5 days. I established the PC-3 and SKMEL-5 cell lines in HyClone RPMI-1640 Medium (Thermo Scientific SH 30027.01 ) with $10 \%$ Fetal Bovine Serum and 1\% Antibiotic and Antimycotic 
Solution. PC-3 cells grew quickly to confluency in 1-2 days while the SKMEL-5 cells took slightly longer (3-4 days). All cell lines were incubated at $37^{\circ} \mathrm{C}$ with $100 \%$ humidity and $5 \%$ carbon dioxide.

I added cells to flat-bottomed 96-well plates with suitable medium and allowed them to grow to confluency. For a preliminary screening of the 34 extracts and 3 cell lines, I pipette plant extracts into wells to make $200,100,50$, and $25 \mu \mathrm{g} / \mathrm{ml}$ concentrations in duplicate. Cells grew in the presence of the extracts for 18 hours. As the extracts are colored and might prevent accurate dye readings, I removed spent media from the wells and added fresh media with 10\% Alamar Blue (AbD Serotec BUF012B). After waiting 4 hours (O'Brien, et al. 2000), I graded well color on a scale from 1 to 5. Red was scored 1(reduced and viable), 2 was reddish purple, 3 was purple, 4 was bluish-purple, and 5 was blue (nonviable).

From these data, I used a more rigorous screening to evaluate extracts that showed inhibition at concentrations of $100 \mu \mathrm{g} / \mathrm{ml}$ or less against one or multiple cell lines. In the second phase of testing, I serially diluted extracts from $512 \mu \mathrm{g} / \mathrm{ml}$ to $0.5 \mu \mathrm{g} / \mathrm{ml}$ in wells with fresh confluent cells. The last well was left as a control. Other controls included DMSO, PBS, media, and camptothecin, a known lethal phytochemical for human cells. After 18 hours, I removed spent media and added fresh media with 10\% Alamar Blue. After 4 hours and 18 hours, the plates were read in a Bio-Tek Synergy HT

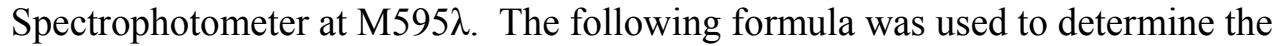
difference in growth between absorbance at $595 \mathrm{~nm}$ of the treatment group, or the wells with extracts, and absorbance at $595 \mathrm{~nm}$ of the control group, or untreated wells showing normal growth for each cell line. Percent viability was calculated for each concentration 
of each extract and then triplicates were averaged. Note that percent viability (used in the cytotoxicity assay) is the inverse of percent inhibition (used in the anti-bacterial assay).

$$
\text { Viability }=\left(\frac{\mathrm{Abs}_{595}}{\text { AbsControl }_{595}}\right) \times 100
$$

\section{RESULTS}

\section{Anti-Bacterial Assay}

The first anti-bacterial screening identified 20 of the 34 crude extracts that inhibited at least one strain of bacteria (Table 4.3).

Table 4.3 Results from the Initial Bioassay showing MICs $(\mu \mathrm{g} / \mathrm{ml})$ of any crude extracts that exhibited bacterial inhibition against one or more bacterial pathogens

\begin{tabular}{|c|c|c|c|c|c|c|c|c|c|c|c|c|c|c|}
\hline \multirow[b]{2}{*}{ Extracts } & \multicolumn{14}{|c|}{ Bacteria } \\
\hline & Bs & Ec & Ef & Kр & Lm & $\mathbf{P a}$ & Se & St & $\mathbf{S a}$ & Sf & Ss & Vp & Ye & $\mathbf{Y u}$ \\
\hline AC met & & 512 & & & & & & & 256 & & & 256 & 512 & \\
\hline AM met & & 256 & & & 256 & & & & & & & 512 & 128 & \\
\hline CO met & & 512 & & & & & & & & & & & & \\
\hline HP met & 256 & 128 & 64 & & 64 & & & & 64 & 512 & 256 & 32 & 128 & \\
\hline ML met & & 256 & & & & & & & 256 & & & 128 & & \\
\hline PR met & 256 & 128 & & & 256 & & & & & & 256 & 128 & & \\
\hline RhC met & 256 & 8 & & & 64 & & & & 256 & 512 & 64 & & 64 & 64 \\
\hline RoCF met & 128 & 512 & & & 128 & & & & & & 512 & 32 & & 64 \\
\hline RoCF aq & & & & & & & & & & & & & & 256 \\
\hline RoCG met & & 128 & & & 64 & 64 & & 512 & 256 & 128 & 256 & 16 & 256 & 256 \\
\hline RPF met & & 512 & & & 128 & & & & 256 & & 512 & & & 256 \\
\hline RPL met & 256 & & & & 128 & & & & & & & 512 & & \\
\hline TF met & 128 & 512 & & & 64 & & & & 256 & & & 256 & & 256 \\
\hline TF aq & & & & & & & & & & & & 128 & & \\
\hline TP met & 256 & 512 & & & 32 & & & & 128 & & & 256 & & 256 \\
\hline TP aq & & & & & & & & & & & & 512 & & \\
\hline TT met & 128 & 256 & & & 64 & & & & & & & 256 & & \\
\hline UD met & 256 & 128 & & & 32 & & & & 256 & & & 256 & & \\
\hline VAA met & 64 & 256 & & & 16 & & & & 256 & & & & & 128 \\
\hline VAC met & 256 & 128 & & & 16 & & 64 & & 256 & & 512 & 32 & 256 & \\
\hline
\end{tabular}

MICs are the lowest 2 out of triplicates. Abbreviations for plants and bacteria names can be found in List of Plants (Table 4.1) and List of Bacteria (Table 4.2). Cells left blank when no inhibition was observed within the concentration range. 
Using these data (Table 4.3), the five extracts that inhibited the most bacteria at the lowest concentrations were selected for further investigation in the secondary phase of the anti-bacterial assay. Methanolic extracts of Hypericum perforatum, Rhus coriaria, Rosa canina fruits, $R$. canina galls, and Vitex agnus-castus were selected because these plant extracts inhibited a total of $9,8,6,10$, and 8 bacteria strains, respectively. The resulting $\mathrm{MIC}_{50}$ and $\mathrm{MIC}_{90}$ of the five extracts and the five antibiotic controls are tallied in Table 4.4 below.

Table 4.4 $\mathrm{MIC}_{50}$ and $\mathrm{MIC}_{90}$ for the five most-inhibitive extracts and five antibiotics for clinically relevant comparisons

\begin{tabular}{|c|c|c|c|c|c|c|c|c|c|c|c|}
\hline \multirow{2}{*}{\multicolumn{2}{|c|}{ Bacteria }} & \multicolumn{5}{|c|}{ Five Plant Extracts } & \multicolumn{5}{|c|}{ Five Antibiotics } \\
\hline & & \multirow{2}{*}{\begin{tabular}{r|}
$\mathbf{H P}$ \\
128 \\
\end{tabular}} & \multirow{2}{*}{$\begin{array}{r}\text { RhC } \\
64\end{array}$} & \multirow[t]{2}{*}{ RoCF } & \multirow{2}{*}{$\begin{array}{r}\text { RoCG } \\
4\end{array}$} & \multirow{2}{*}{$\begin{array}{r}\mathbf{V A C} \\
128\end{array}$} & \multirow{2}{*}{$\begin{array}{r}\text { Cipro } \\
0.5\end{array}$} & \multirow{2}{*}{$\begin{array}{r}\text { Azithro } \\
<0.25\end{array}$} & \multirow{2}{*}{$\frac{\text { Amp }}{<0.25}$} & \multirow{2}{*}{\begin{tabular}{r|} 
Nitro \\
16 \\
\end{tabular}} & \multirow{2}{*}{$\begin{array}{c}\text { Vanco } \\
<0.25\end{array}$} \\
\hline Bs-1 & MIC50 & & & & & & & & & & \\
\hline & MIC90 & & 512 & & & 512 & 1 & 0.5 & 0.5 & 32 & 0.5 \\
\hline \multirow[t]{2}{*}{ Ec-0 } & MIC50 & 512 & 512 & 512 & 256 & & 0.25 & 0.5 & 4 & $<0.25$ & 32 \\
\hline & MIC90 & & & & 512 & & 0.5 & 4 & 8 & 0.25 & 128 \\
\hline \multirow[t]{2}{*}{ Ec-1 } & MIC50 & & 512 & & 64 & 512 & $<0.25$ & $<0.25$ & 1 & 4 & 64 \\
\hline & MIC90 & & & & 512 & & 0.25 & 0.5 & 2 & 8 & 256 \\
\hline \multirow[t]{2}{*}{ Ef-1 } & MIC50 & 64 & 256 & & 256 & 256 & 1 & $<0.25$ & 1 & 16 & 0.25 \\
\hline & MIC90 & 512 & & & 512 & & 4 & 0.5 & 2 & 64 & 0.5 \\
\hline \multirow[t]{2}{*}{ Kp-1 } & MIC50 & 256 & 256 & 128 & 64 & 64 & 128 & 4 & & 128 & 128 \\
\hline & MIC90 & & & & 256 & & 256 & 16 & & 256 & 512 \\
\hline \multirow[t]{2}{*}{ Lm-1 } & MIC50 & 512 & 256 & 512 & 128 & 256 & 1 & 0.5 & 1 & 16 & 16 \\
\hline & MIC90 & & 512 & & 512 & 512 & 8 & 1 & 2 & 32 & 128 \\
\hline \multirow[t]{2}{*}{ Lm-2 } & MIC50 & 64 & 128 & 512 & 128 & 64 & $<0.25$ & $<0.25$ & $<0.25$ & 8 & 0.25 \\
\hline & MIC90 & 128 & 256 & & 256 & 128 & 1 & $<0.25$ & $<0.25$ & 16 & 0.5 \\
\hline \multirow[t]{2}{*}{ Pa-1 } & MIC50 & 128 & 32 & 128 & 8 & 128 & 1 & 0.5 & 512 & 256 & 128 \\
\hline & MIC90 & 512 & 256 & 512 & 128 & 512 & 4 & 2 & & 512 & \\
\hline \multirow[t]{2}{*}{ Sa-1 } & MIC50 & 128 & 256 & 512 & 64 & 64 & 0.5 & $<0.25$ & $<0.25$ & 16 & 0.5 \\
\hline & MIC90 & 512 & 512 & & 512 & 512 & 2 & 0.25 & $<0.25$ & 32 & 1 \\
\hline \multirow[t]{2}{*}{ Sa-2 } & MIC50 & 256 & 256 & & 128 & 256 & 0.25 & $<0.25$ & $<0.25$ & 16 & 0.5 \\
\hline & MIC90 & 512 & 512 & & 512 & 512 & 2 & $<0.25$ & 0.25 & 32 & 1 \\
\hline \multirow[t]{2}{*}{ Sa-3 } & MIC50 & 256 & 256 & 256 & 128 & 256 & 2 & 0.25 & $<0.25$ & 16 & 1 \\
\hline & MIC90 & 512 & 512 & 512 & 512 & 512 & 8 & 0.5 & $<0.25$ & 32 & 2 \\
\hline \multirow[t]{2}{*}{$\mathrm{Sa}-4$} & MIC50 & 256 & 256 & 256 & 128 & 256 & 1 & 0.25 & 0.5 & 16 & 0.5 \\
\hline & MIC90 & 512 & 512 & 512 & 512 & 512 & 4 & 0.5 & 1 & 32 & 1 \\
\hline
\end{tabular}




\begin{tabular}{|c|c|c|c|c|c|c|c|c|c|c|c|}
\hline \multirow[t]{2}{*}{ Se-1 } & MIC50 & & 512 & & 128 & 512 & $<0.25$ & 0.5 & 1 & 8 & 128 \\
\hline & MIC90 & & & & 256 & & $<0.25$ & 1 & 2 & 16 & 256 \\
\hline \multirow[t]{2}{*}{ Sf-1 } & MIC50 & 128 & 64 & 256 & 16 & 128 & $<0.25$ & $<0.25$ & 2 & 4 & 4 \\
\hline & МIC90 & & 512 & & 128 & 256 & $<0.25$ & $<0.25$ & 4 & 8 & 8 \\
\hline \multirow[t]{2}{*}{ Ss-1 } & MIC50 & 512 & 256 & 512 & 128 & 128 & $<0.25$ & 0.5 & 1 & 4 & 16 \\
\hline & MIC90 & & & & 512 & & $<0.25$ & 1 & 2 & $>512$ & 128 \\
\hline \multirow[t]{2}{*}{ St-4 } & MIC50 & 128 & 128 & 256 & 16 & 128 & $<0.25$ & 0.5 & 0.5 & 4 & 64 \\
\hline & MIC90 & & & & 512 & & $<0.25$ & 1 & 1 & 16 & 256 \\
\hline \multirow[t]{2}{*}{ Vp-1 } & MIC50 & & 128 & 256 & 16 & 512 & 0.25 & $<0.25$ & 1 & 4 & 16 \\
\hline & МIC90 & & 512 & & 64 & & 0.5 & $<0.25$ & 4 & 8 & 32 \\
\hline \multirow[t]{2}{*}{ Ye-1 } & MIC50 & 64 & 64 & 64 & 8 & 64 & $<0.25$ & 0.25 & 4 & 1 & 4 \\
\hline & МIC90 & & 512 & 512 & 256 & 512 & $<0.25$ & 0.5 & 8 & 32 & 128 \\
\hline \multirow[t]{2}{*}{ Ye-2 } & MIC50 & 128 & 128 & 128 & 64 & 256 & 0.25 & $<0.25$ & 8 & 8 & 8 \\
\hline & MIC90 & & 512 & & 128 & 512 & 0.5 & $<0.25$ & 16 & 16 & 256 \\
\hline \multirow[t]{2}{*}{ Yu-1 } & MIC50 & 64 & 256 & 64 & 128 & 32 & 0.25 & 1 & 0.25 & 64 & 16 \\
\hline & MIC90 & 256 & 512 & 512 & 512 & 512 & 0.5 & 4 & 0.5 & & 256 \\
\hline \multirow[t]{2}{*}{ Yu-2 } & MIC50 & 512 & 256 & 512 & 128 & 512 & 0.5 & 0.5 & $<0.25$ & 32 & 8 \\
\hline & MIC90 & & 512 & & 512 & & 1 & 4 & $<0.25$ & 64 & 512 \\
\hline
\end{tabular}

Abbreviations for plants and bacteria names can be found in List of Plants (Table 4.1) and List of Bacteria (Table 4.2). Blank cells denote no observed inhibition within concentration range.

When MICs of $64 \mu \mathrm{g} / \mathrm{ml}$ or lower were reached (Table 4.4), the data were analyzed statistically for significant differences between concentrations using separate ANOVAs with Tukey post-hoc tests for each extract and bacterial strain (Table 4.5). Methanolic crude extracts of $H$. perforatum, a plant often used as a mood elevator, inhibited $L$. monocytogenes at $32 \mu \mathrm{g} / \mathrm{ml}$ and $Y$. pseudotuberculosis at $16 \mu \mathrm{g} / \mathrm{ml}$. Methanolic crude extract of $R$. coriaria inhibited $B$. subtilis at $256 \mu \mathrm{g} / \mathrm{ml}$, but it also inhibited $P$. aeruginosa and $S$. flexneri at low concentrations of $16 \mu \mathrm{g} / \mathrm{ml}$. Methanolic extract of $V$. agnus-castus inhibited three bacteria (K. pneumonia, L. monocytogenes, and S. aureus) at $32 \mu \mathrm{g} / \mathrm{ml}$ and Y. pseudotuberculosis at $16 \mu \mathrm{g} / \mathrm{ml}$.

Methanolic extracts of $R$. canina were prepared from rosehips and galls of rosehips produced by cynipid wasps. The rosehip methanolic extract inhibited $Y$. pseudotuberculosis at $256 \mu \mathrm{g} / \mathrm{ml}$. The gall extract did not significantly inhibit $Y$. 
pseudotuberculosis in this assay. However, methanolic crude gall extract inhibited several other bacteria. Yersinia enterocolitica, S. enterica typhimurium, K. pneumonia, and B. subtilis were inhibited at $256 \mu \mathrm{g} / \mathrm{ml}$. Staphylococcus aureus was inhibited by methanolic extract of $R$. canina galls at $128 \mu \mathrm{g} / \mathrm{ml}$, while $E$. coli growth was inhibited at $64 \mu \mathrm{g} / \mathrm{ml}$. In even smaller concentrations, $R$. canina methanolic gall extract inhibited $E$. faecalis and $S$. flexneri at $32 \mu \mathrm{g} / \mathrm{ml}, V$. parahaemolytics at $8 \mu \mathrm{g} / \mathrm{ml}$, and $P$. aeruginosa at $4 \mu \mathrm{g} / \mathrm{ml}$.

Table 4.5 Significant MIC $(\mu \mathrm{g} / \mathrm{ml})$ results statistically analyzed by ANOVA and Tukey post-hoc tests for top five extracts and inhibited bacterial pathogens

\begin{tabular}{|l|r|r|r|r|r|r|r|r|r|r|r|r|}
\hline Top 5 & \multicolumn{10}{|c|}{ Bacteria } \\
\cline { 2 - 14 } \\
HPtracts & Bs & Ec & Ef & Kp & Lm & Pa & Sa & Sf & St & Vp & Ye & Yu \\
\hline RhC & & & & & 32 & & & & & & & 16 \\
\hline RoCF & & & & & & & & & & & & 256 \\
\hline RoCG & 256 & 64 & 32 & 256 & & 4 & 128 & 32 & 256 & 8 & 256 & \\
\hline VAC & & & & 32 & 32 & & 32 & & & & & 16 \\
\hline
\end{tabular}

Each extract and bacteria were analyzed separately from other extracts and bacteria. Differences in bacterial growth (OD) between extract concentrations were significant at $p<0.05$. Abbreviations for plants and bacteria names can be found in List of Plants (Table 4.1) and List of Bacteria (Table 4.2). Blank cells denote no significant inhibition within concentration range.

Because the methanolic extracts of $R$. canina showed such high rates of inhibition at low concentratios for 10 of the 21 bacteria in this study, they were selected for further analysis by bioassay-guided fractionation (see Chapter V).

Significant differences in $\left[\mathrm{OD}_{\text {Tpeak }}-\mathrm{OD}_{\text {Tinitial }}\right]$ were compared between concentrations for each extract that showed inhibition of growth in specific bacteria. The differences were further analyzed by Tukey post-hoc tests to determine significant differences $(p<0.05)$ and plotted for visual clarity. 


\section{Cytotoxicity Assay}

The majority of the extracts showed no cytotoxicity toward the tested human cells. However, 13 out of 34 showed some form of toxicity in the initial screening, when bluered color changes were judged by eye (Table 4.5). Prostate (PC-3) and skin melanoma (SkMEL-5) cell lines were more sensitive than the hepatocytes (HepG-2) to the plant extracts, especially the methanolic extracts. Although DMSO was the solvent vehicle for the methanolic extracts, the controls showed no inhibitory effect of DMSO in the cell lines. The DMSO was kept to $<5 \%$ of total well volume. For hepatocytes, methanolic extracts of $H$. perforatum, R. coriaria, R. patientia fruits, and V.agnus-castus showed inhibition at $25 \mu \mathrm{g} / \mathrm{ml}$ and $5 \mu \mathrm{g} / \mathrm{ml}$. Extracts that showed inhibition at $100 \mu \mathrm{g} / \mathrm{ml}$ or less in the preliminary screening were evaluated in the more elaborate secondary screening process.

Table 4.5 Results of the Preliminary Alamar Blue Assay showing any IC's of $100 \mu \mathrm{g} / \mathrm{ml}$ or less. (Non-toxic results are not shown).

\begin{tabular}{|l|c|c|c|c|c|}
\hline Plant & Solvent & Extract \# & PC-3 & SkMEL-5 & HepG-2 \\
\hline Ajuga chamaepitys & $\mathrm{MeOH}$ & 1 & 100 & 50 & 200 \\
\hline Achillea millefolium & $\mathrm{MeOH}$ & 3 & 100 & 50 & 50 \\
\hline Hypericum perforatum & $\mathrm{MeOH}$ & 7 & 25 & 5 & 25 \\
\hline Mentha longifolia & $\mathrm{MeOH}$ & 9 & 100 & 5 & 200 \\
\hline Rhus coriaria & $\mathrm{MeOH}$ & 13 & 5 & 5 & 25 \\
\hline Rosa canina galls & $\mathrm{MeOH}$ & 17 & 50 & 100 & 200 \\
\hline Rumex patientia fruits & $\mathrm{MeOH}$ & 19 & 100 & 50 & 25 \\
\hline Rumex patientia leaves & $\mathrm{MeOH}$ & 21 & 200 & 25 & 200 \\
\hline Tribulus terrestris & $\mathrm{MeOH}$ & 27 & 50 & 5 & 50 \\
\hline Tribulus terrestris & $\mathrm{Aq}$ & 28 & 25 & 100 & 50 \\
\hline Urtica dioica & $\mathrm{MeOH}$ & 29 & 100 & 5 & 50 \\
\hline Vitex agnus-castus & $\mathrm{MeOH}$ & 31 & 5 & 5 & 5 \\
\hline Viscum album & $\mathrm{MeOH}$ & 33 & 200 & 50 & 100 \\
\hline DMSO & & 35 & 200 & 200 & 200 \\
\hline PBS & & 36 & 200 & 200 & 200 \\
\hline CAMPTOTHECIN & & 37 & 5 & 50 & 5 \\
\hline
\end{tabular}


Although the aqueous extract of $T$. terrestris inhibited PC-3 cells (78.4\% viability at $32 \mu \mathrm{g} / \mathrm{ml}$ and $85.3 \%$ viability at $64 \mu \mathrm{g} / \mathrm{ml}$ ), these differences were not significant at $\mathrm{p}<0.05$. Urtica dioica methanolic extract showed minor inhibition of PC-3 cell growth with $82.6 \%$ viability at $64 \mu \mathrm{g} / \mathrm{ml}$ and $89.3 \%$ viability at $32 \mu \mathrm{g} / \mathrm{ml}$. Vitex agnus-castus methanolic extract showed slight inhibition of PC-3 cells with $85.9 \%$ viability at $32 \mu \mathrm{g} / \mathrm{ml}$ and $86.6 \%$ viability at $64 \mu \mathrm{g} / \mathrm{ml}$. However, the overall inhibition of human cell lines was negligible in the secondary cytotoxicity screening that utilized spectrophotometric readings. In fact, the extracts seemed to help the human cells grow, with most viability percentages over $100 \%$ and no $\mathrm{MIC}_{50}$ or $\mathrm{MIC}_{90}$ reached.

\section{DISCUSSION}

\section{Anti-bacterial Properties}

Of the fifteen Turkish anti-diarrheal plants assayed in this study, all inhibited, to some degree, one or more bacterial strains. Besides the top five plants analyzed, three methanolic extracts inhibited L. monocytogenes at low concentrations. T. polium and $U$. dioica inhibited L. monocytogenes at $32 \mu \mathrm{g} / \mathrm{ml}$ while $V$. album inhibited L. monocytogenes at $16 \mu \mathrm{g} / \mathrm{ml}$. These three plants were commonly used to treat diarrhea and a wide variety of gastrointestinal ailments and auto-immune complaints. The severity of diarrhea has been linked to increases in interleukins and other inflammatory signals in the intestines. The mistletoe $V$. album grows on oak, pear, and other tree species in Central Anatolia. Locals and botanists (Türe, et al. 2010) reported that $V$. album harvested from different trees bear different medicinal or chemical properties. Following local use patterns, only V. album from pear trees was used to prepare extracts. 
Hypericum perforatum exhibits a variety of biological activities, including activity against Gram positive bacteria and MRSA, but the plant's anti-bacterial properties are not exhaustively known (Saddiqe, et al. 2010). In part, the variation in reports of antibacterial activity might be the result of seasonal changes in chemical concentrations of $H$. perforatum (Borchardt, et al. 2008). Previous research has analyzed the essential oils of Serbian H. perforatum against several Gram negative and Gram positive bacteria to great effect (Saroglou, et al. 2007). In the present study, methanolic extractions of $H$. perforatum inhibited Gram negative L. monocytogenes at $32 \mu \mathrm{g} / \mathrm{ml}$ and $Y$. pseudotuberculosis at $16 \mu \mathrm{g} / \mathrm{ml}$.

Rhus coriaria is commonly used as sumac spice throughout much of the Middle East. Methanolic extract of $R$. coriaria inhibited P. aeruginosa and S. flexneri at $16 \mu \mathrm{g} / \mathrm{ml}$. Both $P$. aeruginosa and $S$. flexneri are infectious agents with growing resistance to prophylactic treatments, and new treatments would prove beneficial. Previous research of antibacterial properties of aqueous extracts of $R$. coriaria ripened and unripened fruits showed inhibition of mostly Gram positive bacteria including $S$. aureus, as well as some Gram negative bacteria including E. coli and Proteus sp. (Nasar-Abbasa and Halkman 2004). Other investigations showed inhibition of Moraxella catarrhalis (syn.

Branhamella catarrhalis) (Sokmen, et al. 1999), as well as MRSA at high concentrations (Abu-Shanab, et al. 2005), and other Gram positive strains (Khalil 1996).

The methanolic extract of $V$. agnus-castus fruits inhibited $K$. pneumoniae, $S$. aureus, and L. monocytogenes at $32 \mu \mathrm{g} / \mathrm{ml}$. Klebsiella pneumoniae is particularly difficult to inhibit. Also, in this study V. agnus-castus inhibited Y. pseudotuberculosis at $16 \mu \mathrm{g} / \mathrm{ml}$, a clinically relevant concentration. Previous studies of V. agnus-castus in India showed that ethyl acetate extracts of the leaves inhibited MRSA (Arokiyaraj, et al. 2009). 
Hexanic and dichloromethanic extracts of Vitex trifolia are cytotoxic against several cancer lines in (Hernández, et al. 1999). Several South African Vitex species inhibited the growth of Gram positive bacteria more than Gram negative bacteria (Nyiligira, et al. 2008). More hydrophobic preparations of leaves were used in previous studies, while more hydrophilic preparations of the fruits were used in the present research.

Methanolic extracts of $R$. canina fruits inhibited Y. pseudotuberculosis at $256 \mu \mathrm{g} / \mathrm{ml}$. Previous research on the antibacterial properties of $R$. canina showed that methanolic extracts of seeds inhibited E. coli (ATCC 8110), while hexane and dichloromethane extracts showed no inhibition (Kumarasamy, et al. 2002). Another study examined the use of common antibiotics (ß-Lactams) with $R$. canina in treating MRSA, with synergistic results (Shiota, et al. 2000).

The antibacterial properties of $R$. canina galls have not been previously reported nor analyzed in bioassays. Galls result from complex biochemical interactions between an insect, parasites to that insect, the plant host, and possible microorganisms. The signaling and biochemical changes are not fully understood. In this study, methanolic extracts of $R$. canina galls inhibited several bacteria: $P$. aeruginosa at $4 \mu \mathrm{g} / \mathrm{ml}, V$. parahaemolyticus at $8 \mu \mathrm{g} / \mathrm{ml}$, E. faecalis and $S$. flexneri at $32 \mu \mathrm{g} / \mathrm{ml}$. With intrinsic resistance to a variety of antibiotics, $P$. aeruginosa and $E$. faecalis constitute serious concerns as nosocomial infections. Vibrio parahaemolyticus and S. flexneri play a significant role in severe diarrhea epidemics. Rosa canina galls show promise as possible antibacterial agents. Similarly, in southeastern Turkey, villagers commonly used galls from oak trees, induced by a closely related wasp, to treat diarrhea. 


\section{Cytotoxicity}

Since the plants under study are commonly ingested by people as spices or for medicines, their cytotoxicity levels were expected to be low. In the preliminary cytotoxicity assay, read as changes in dye color, 13 of 34 plant extracts showed inhibition or death to one or more human cell lines. However, in the secondary cytotoxicity assay in which a spectrophotometer read color wavelengths of the dye, growth was not significantly inhibited in the human cell lines.

In vivo, the ingestion of phytochemicals commonly alters their chemical composition. The acidity of the stomach and secretions of the intestines, pancreas and liver can change the ionic valences or bonded structures of phytochemicals. Enzymes known as cytochrome P450s (CYPs) in humans, plants, bacteria, and all life forms metabolize and activate thousands of exogenous compounds, and are known to interact with phytochemicals (Budzinski, et al. 2007). Drug-transport proteins like Pglycoproteins (P-gps) efflux foreign chemicals back into the lumen (Nair, et al, 2007). Humans are well-equipped to metabolize plant compounds. Also, most of the plants used in traditional Turkish villages were extracted with water, which pulls hydrophilic chemicals out of the plants. The non-toxic aqueous extracts are more representative of what was actually ingested in villages than the methanolic extracts.

\section{CONCLUSIONS}

To answer the tested hypotheses: H1. Several Central Anatolian anti-diarrheal plants inhibited different strains of bacteria. H2. There was a marked difference in bioactivity between methanolic and aqueous extracts, with methanolic extracts inhibiting bacteria more frequently and at much lower concentrations than traditionally used 
aqueous extracts. H3. Central Anatolian anti-diarrheal plants showed insignificant cytotoxicity to the cell lines in the Alamar Blue Cytotoxicity Assay, and are therefore safe for consumption. Regarding whether the data support the use of traditional medicines in Central Anatolia: H4. While several methanolic extracts inhibited bacteria, the more traditional aqueous extracts showed little inhibition when compared to methanolic extract activity. However, cytotoxicity levels were low. Therefore, plants were safe to ingest as treatments. The assay in this study did not detect anti-bacterial activity in aqueous extracts, but a different assay could elucidate bioactivities of aqueous extracts.

Plant extracts that showed the highest rates of inhibition against bacteria included H. perforatum, R. coriaria, R. canina, and V.agnus-castus. The methanolic extracts of these plants inhibited bacteria at concentrations as low as $4 \mu \mathrm{g} / \mathrm{ml}$ (MIC of $R$. canina galls against $P$. aeruginosa). Further analysis of the $R$. canina galls has been undertaken and will be described in the following chapter.

Overall, seven plants used in traditional Turkish pharmacopeias to treat diarrhea showed antibacterial properties at clinically relevant levels $(\leq 32 \mu \mathrm{g} / \mathrm{ml})$. Also, the plants appear safe for consumption. Promising results include the effectiveness of U. dioica, $T$. polium, and $V$. album in inhibiting L. monocytogenes. Vitex agnus-castus showed high inhibition in K. pneumoniae, which is a difficult bacteria to inhibit. Future studies that examine the effectiveness of $R$. canina galls or $R$. coriaria fruits against $P$. aeruginosa would benefit many patients, as would the study of $R$. canina gall extracts in inhibiting $V$. parahaemolyticus. Several results show promise for future work in bacterial inhibition of Turkish anti-diarrheal plants. 


\section{ACKNOWLEDGMENTS}

This research was funded in part by a J. William Fulbright Foreign Scholarship Award, the Turkish Fulbright Commission, an NIH MBRS/RISE fellowship, and a Summer Biomedical Research Initiative (NIH NIGMS R25 GM 061347) through FIU.

Dr. John Berry allowed the appreciable use of his laboratory for the cytotoxicity assay. Special thanks goes to Dr. Kalai Mathee of FIU for strains of $P$. aeruginosa (PA01), E. coli (Ec-0, Nat OH5- $\alpha$ ), and S. aureus (Sa-1). Maria Rojas facilitated the acquisition of E. faecalis, and Dr. Alejandro Barbieri's laboratory allowed the use of $L$. monocytogenes and K. pneumoniae. The strains of S. enterica typhimurium (St-4), $Y$. pseudotuberculosis (Yu-1, III YP KmR) and Y. enterocolitica were generously contributed by Dr. Gary Plano, of the University of Miami. The former Center for Ethnobiology and Natural Products at FIU supplied several other strains, spectrophotometric instruments, and laboratory space.

\section{REFERENCES}

Abu-Shanab, B., Adwan, G., Abu-Safiya, D., Adwan, K., Abu-Shanab, M., 2005. Antibacterial Activity of Rhus coriaria L. Extracts Growing in Palestine. Journal of The Islamic University of Gaza, (Natural Sciences Series). 13(2), 147-153.

Amsterdam, D., 1996. Susceptibility Testing for Antimicrobials in Liquid Media, in: Loman, V. (Ed.), Antibiotics in Laboratory Medicine. Williams \& Wilkins, Baltimore, MD, pp. 52-111.

Arokiyaraj, S., Perinbam, K., Agastian, P., Kumar, R. M., 2009. Phytochemical Analysis and Antibacterial Activity of Vitex agnus-castus. International Journal of Green Pharmacy. April-June, 162-164.

Barry, A., Craig, W., Nadler, N., Barth Reller, L., Sanders, C., Swenson, J., 1999. M26-A, Methods for Determining Bactericidal Activity of Antimicrobial Agents; Approved Guideline. NCCLS Catalog, now Clinical and Laboratory Standards Institute (CLSI). 19(18), 1-30. 
Borchardt, J. R., Wyse, D. L., Sheaffer, C. C., Kauppi, K. L., Fulcher, R. G., Ehlke, N. J., 2008. Antimicrobial activity of native and naturalized plants of Minnesota and Wisconsin. Journal of Medicinal Plants Research. 2, 98-110.

Budzinski, J. W., Trudeau, V. L., Drouin, C. E., Panahi, M., Arnason, J. T., Foster, B. C., 2007. Modulation of human cytochrome P450 3A4 (CYP3A4) and P-glycoprotein (P-gp) in Caco-2 cell monolayers by selected commercial-source milk thistle and goldenseal products. Canadian Journal of Physiology and Pharmacology. 85, 966-978.

Davis, P. H., 1965. Flora of Turkey and the East Aegean Islands, vol. 1 of 11. Edinburgh University Press, Edinburgh.

Gloeckner, H., Jonuleit, T., Lemke, H.-D., 2001. Monitoring of cell viability and cell growth in a hollow-fiber bioreactor by use of the dye Alamar Blue TM. Journal of Immunological Methods. 252, 131-138.

Guerrant, R., Kosek, M., Moore, S., Lorntz, B., Brantley, R., Lima, A., 2002. Magnitude and Impact of Diarrheal Diseases. Archives of Medical Research. 33, 351-355.

Güner, A., Ozhatay, N., Ekim, T., Husnu, K., Baser, C., Hedge, I., 2001. Flora of Turkey and the East Aegean Islands, vol. 11 of 11. Edinburgh University Press, Edinburgh.

Hernández, M. M., Heraso, C., Villarreal, M. L., Vargas-Arispuro, I., Aranda, E., 1999. Biological activities of crude plant extracts from Vitex trifolia L. (Verbenaceae). Journal of Ethnopharmacology. 67, 37-44.

Isenberg, H.D., 2004. Clinical Microbiology Procedures Handbook. ASM Press, Washington, D.C.

Khalil, M., 1996. Antimicrobial Properties of Rhus coriaria seeds (Sumach). Journal of King Saudi University. 8(2), 257-267.

Kumarasamy, Y., Cox, P. J., Jaspars, M., Nahar, L., Sarker, S. D., 2002. Screening Seeds of Scottish Plants for Antibacterial Activity. Journal of Ethnopharmacology. 83, 73-77.

Levine, M., Svennerholm, A. M., 2008. Immunoprophylaxis and Immunologic Control, in: Ericsson, C. (Ed.), Traveler's Diarrhea. BC Deck, Inc., Hamilton, Ontario, pp. 215232.

Nair, V. D. P., Foster, B. C., Arnason, J. T., Mills, E. J., Kanfer, I., 2007. In vitro evaluation of human cytochrome P450 and P-glycoprotein-mediated metabolism of some 
phytochemicals in extracts and formulations of African potato. Phytomedicine. 14, 498507.

Nasar-Abbasa, S.M., Halkman, A. K., 2004. Antimicrobial effect of water extract of sumac (Rhus coriaria L.) on the growth of some food borne bacteria including pathogens. International Journal of Food Microbiology. 97, 63-69.

Nyiligira, E., Viljoen, A. M., Van Heerden, F. R., Van Zyl, R. L., Van Vuurena, S. F., Steenkamp, P. A., 2008. Phytochemistry and in vitro pharmacological activities of South African Vitex (Verbenaceae) species. Journal of Ethnopharmacology 119, 680-685.

O'Brien, J., Wilson, I., Orton, T., Pognan, F., 2000. Investigation of the Alamar Blue (resazurin) fluorescent dye for the assessment of mammalian cell cytotoxicity. European Journal of Biochemistry. 267(17), 5421-5426.

Palombo, E., 2006. Phytochemicals from traditional medicinal plants used in the treatment of diarrhoea: Modes of action and effects on intestinal function. Phytotherapy Research. 20, 717-724.

Peel, M. C., Finlayson, B. L., McMahon, T. A., 2007. Updated world map of the KöppenGeiger climate classification. Hydrology and Earth System Sciences. 11, 1633-1644.

Quave, C., Plano, L. R. W., Pantuso, T., Bennett, B., 2008. Effects of extracts from Italian medicinal plants on planktonic growth, biofilm formation and adherence of methicillinresistant Staphylococcus aureus. Journal of Ethnopharmacology. 118, 418-428.

Saddiqe, Z., Naeem, I., Maimoona, A., 2010. A Review of the Antibacterial Activity of Hypericum perforatum L. Journal of Ethnopharmacology. 131, 511-521.

Sanchez, J., Holmgren, J., 2005. Virulence factors, pathogenesis and vaccine protection in cholera and ETEC diarrhea. Current Opinion in Immunology. 17, 388-398.

Saroglou, V., Marin, P., D., Rancic, A., Veljic, M., Skaltsa, H., 2007. Composition and antimicrobial activity of the essential oil of six Hypericum species from Serbia. Biochemical Systematics and Ecology. 35, 146-152.

Shiota, S., Shimizu, M., Mizusima, T., Ito, H., Hatano, T., Yoshida, T., 2000. Restoration of effectiveness of $\beta$-lactams on methicillin-resistant Staphylococcus aureus by tellimagrandin I from rose red. FEMS Microbiology Letters. 185, 135-138.

Sokmen, A., Jones, B., Erturk, M., 1999. The in vitro Antibacterial Activity of Turkish Medicinal Plants. Journal of Ethnopharmacology. 67, 79-86. 
Türe, C., Böcük, H., Aşan, Z., 2010. Nutritional relationships between hemi-parasitic mistletoe and some of its deciduous hosts in different habitats. Biologia. 65(5), 859-867.

WHO, 2009. Diarrhoeal Diseases. World Health Organization, Geneva. 


\title{
Chapter V
}

\section{IDENTIFICATION OF ELLAGIC ACID AS THE ANTI-BACTERIAL COMPONENT OF ROSA CANINA L. (DOG ROSE) GALLS}

\begin{abstract}
In the spring of 2009, I conducted ethnobotanical fieldwork with villagers of Central Anatolia, Turkey, and gathered information about plant-based remedies used to treat diarrhea. Fifteen of these plants were later evaluated in two microtiter-broth dilution assays for bacterial inhibition. Of the plants collected and tested, the crude methanolic extracts of galls from Rosa canina L. (Rosaceae) showed the lowest minimum inhibitory concentrations (MICs) (from 4 to $64 \mu \mathrm{g} / \mathrm{ml}$ ) against eight bacteria strains. Methanolic extracts of $R$. canina hips (fruits) were less potent (from 128 to $512 \mu \mathrm{g} / \mathrm{ml}$ ). Methanolic gall and fruit extracts were then tested for cytotoxicity and found to exhibit acceptable inhibitory concentrations (ICs) with liver, prostate, and skin cancer cell lines. Finally, $R$. canina fruit and gall extracts were fractionated by high-performance liquid chromatography (HPLC) and analyzed via bioassay-guided fractionation. Using ElectroSpray Ionization Mass Spectrometry (ESI-MS) the active fraction was shown to contain almost pure ellagic acid, a common yet under-studied phytoalexin — a plant defense compound that could be used for human medicines.
\end{abstract}




\section{INTRODUCTION}

For thirty years, international NGOs have worked to halt the millions of deaths per year resulting from diarrheal disease (WHO and UNICEF 2004, WHO 2009). Since the 1980s, the Turkish Ministry of Health has addressed this issue by teaming with WHO and other agencies to sponsor education campaigns for treating diarrhea (The Ministry of Health of Turkey 2004). Most efforts prescribe clean water, hygienic food preparations, and oral-rehydration-therapy (ORT) for treating symptoms. When diarrhea occurs, it usually is first treated at home by a family caregiver with plant-based remedies.

In previous ethnobotanical fieldwork, I described and analyzed the efficacy and cytotoxicity of plant-based remedies for treating diarrhea in rural areas of Turkey (Chapters II, III and IV). The methanolic extract of $R$. canina galls inhibited more bacteria strains at lower doses and was selected for further chemical analysis and bioassay-guided fractionation.

Turkish villagers commonly use $R$. canina to treat a variety of gastrointestinal disorders. The achene-filled pseudofruits of R. canina are called kuşburnu in Turkish, or rosehips in English. Rosehips from $R$. canina are used to treat abdominal pain, diarrhea, hemorrhoids, stomach aches, and kidney stones (Sezik et al., 2001, Tuzlac1 and Aymaz, 2001, Yeşilada et al., 1995, Yeşilada et al., 1999). Rosehips are steeped in hot water and drunk as a tea, but infusions or decoctions of flowers, roots, root bark, and root tumors also are employed. Informants in the region of Çamlidere (100 km north of Ankara) described the use of $R$. canina galls, or fruit tumors, of $R$. canina for therapeutic infusions to treat diarrhea. Rosa canina vouchers (JR0023 and JR0032) were deposited in GAZI.

Rosa canina is a perennial, long-lived shrub which grows throughout the Northern Hemisphere (Shorthouse, 2005). It likely originated in Central Asia, as the area retains 
the highest levels of diversity for several roses, including $R$. canina (Krussmann, 1982). Rosehips have been evaluated for their anti-nociceptive and anti-inflammatory properties in Turkey (Orhan et al., 2007). However, no publications analyzing the medicinal uses of the galls have been found.

Galls are induced in rosehips by cynipid wasps of the Diplolepis genus. Each species of wasp induces galls in different parts of the host plant, creating different morphological features (Redfern and Shirley, 2002). Galls used in this study occured in $R$. canina rosehips; only Diplolepis fructuum Rübsaamen (Hymenoptera: Cynipidae) is known to infect rosehips in Turkey. As much as $90 \%$ of the rosehips in areas of Central Anatolia are infected by $D$. fructuum each year, leading to economic hardships in the rosehip industry (Güçlü et al., 2008).

The interactions between gall-inducing wasps and their host species are not fully understood (Randolph, 2005), yet after eggs are deposited, large amounts of glycerolipids and phosphoglycerides are sequestered to the nutritive cells adjacent to the egg (Bayer, 1994). Nutritive cells of immature Diplolepis spinosa galls on Rosa rugosa displayed zones of inhibition when grown on nutrient agar plates seeded with E.coli or Staphylococcus aureus (Barrett et al., 1998). When grown in the same conditions, normal stem tissue from $R$. rugosa showed no bacterial inhibition.

Rosa canina galls were selected for analysis in this study because of their significant inhibition of multiple bacteria strains. The novelty of studying the biochemical products of an intriguing ecological relationship also led to this choice. The goal was to isolate and identify the chemical compound(s) responsible for the bioactivity demonstrated by $R$. canina gall extracts in previous antibacterial assays. 


\section{METHODS}

\section{Extract preparation}

Using Clinical and Laboratory Standards Institute (CLSI) guidelines (Barry, et al. 1999), I prepared crude extracts from bulk samples collected during field work in Turkey (IRB Approval No. 082508-01). Galls and rosehips were collected from multiple individual plants. I made aqueous extracts via infusion $(1 \mathrm{~g} / 15 \mathrm{ml})$, filtration, freezing, and lyophilizing. Methanol extracts were made via a $72 \mathrm{hr}$ soak $(1 \mathrm{~g} / 20 \mathrm{ml})$ with agitation, filtration, rotary evaporation, and desiccation. Dried methanolic extracts were reconstituted in DMSO $(10 \mathrm{mg} / \mathrm{ml})$ and aqueous extracts were reconstituted in PBS Solution $(10 \mathrm{mg} / \mathrm{ml})$. Stocks were sterile filtered $(0.2 \mu \mathrm{m})$ and stored at $-20^{\circ}$ or $-5^{\circ} \mathrm{C}$.

\section{Anti-Bacterial Assays}

Two microdilution assays were performed. The first assay used 10 bacterial strains from Turkish (Refik Saydam Kültür Koleksiyonu, RSKK) and American (American Type Culture Collection and Northern Regional Research Laboratory) institutes. Gram-negative strains included Escherichia coli (ATCC 35218), Pseudomonas aeruginosa (ATCC 10145), Klebsiella pneumoniae (RSKK 574), Salmonella enteriditis (RSKK 538), Shigella dysenteriae (RSKK 851), and Vibrio cholerae Ojawa (RSKK 96023). Gram-positive strains included Staphylococcus aureus (ATCC 25923), Enterococcus faecalis (ATCC 29212), Bacillus cereus (NRRL B-3711), and Bacillus subtilis (ATCC 6633). Bacteria cultures were grown in Cation-Adjusted Mueller Hinton Broth at $35^{\circ} \mathrm{C}$.

I serially diluted extracts in 96-well plates with concentrations ranging from $512 \mu \mathrm{g} / \mathrm{mL}$ to $0.25 \mu \mathrm{g} / \mathrm{mL}$ with controls for positive growth, media, vehicles, and negative 
growth with antibiotics ampicillin, ciprofloxacin, gentamicin, nitrofurantoin, azithromicin, vancomycin, and TMP-SMX (Barry, et al. 1999). Bacteria were grown to $\log$ phase and suspended at $5 \times 10^{5}$ colony-forming units $(\mathrm{CFU}) / \mathrm{ml}$. Plates were incubated overnight. Assays were completed in triplicate. Wells displaying inhibition or no visible growth were further tested for bactericidal (MBC) or bacteriostatic (MBS) properties. From clear wells, $10 \mu \mathrm{l}$ of well contents were transferred to Mueller Hinton agar plates. After overnight incubation, $\mathrm{CFU} / \mathrm{ml}$ were counted. If no new growth occurred, the previous extract concentration was deemed bactericidal. If bacteria grew, the extract concentration was bacteriostatic.

For the second assay, 21 strains of diarrhea-causing bacteria were challenged (Chapter IV). Bacteria were grown in Cation-Adjusted Mueller Hinton broth at $37^{\circ} \mathrm{C}$. Extracts were serially diluted from $512 \mu \mathrm{g} / \mathrm{mL}$ to $0.25 \mu \mathrm{g} / \mathrm{mL}$ in $96-w e l l$ plates with growth, media, vehicle and antibiotic (ampicillin, ciprofloxacin, nitrofurantoin, azithromicin, and vancomycin) negative controls in triplicate. Bacteria were grown to log phase and diluted to $5 \times 10^{5} \mathrm{CFU} / \mathrm{ml}$. The plates were read for optical density (OD) at $600 \mathrm{~nm}$ wavelength (Biotek PowerWave Spectrophotometer) at initial and peak times for each bacterial strain. Results were calculated as percent inhibitions and minimum inhibitory concentrations (MICs) for 50\% lethality and 90\% lethality. Statistical analyses were performed on PASW SPSS software. One-way ANOVAs with Tukey post-hoc tests were used to evaluate significant differences in categorical data, with significance set at $\mathrm{p}<0.05$. 


\section{Cytotoxicity Assay}

An Alamar Blue Cytotoxicity Assay (O'Brien et al., 2000) was used to determine the concentrations of crude extracts which inhibited human cell growth. Human cell lines included the prostate adenocarcinoma PC-3 (ATCC CRL-1435), the skin melanoma SKMEL-5 (ATCC HTB-70), and the hepatocellular carcinoma HEP G-2 (ATCC CRL11997). Cells were grown in appropriate RPMI and Eagle's Medium, with 10\% Fetal Bovine Serum and $1 \%$ antibiotics.

Cells were grown to confluence at $37^{\circ} \mathrm{C}$ with $100 \%$ humidity and $5 \%$ carbon dioxide. Extracts were introduced in triplicate at a range of $512 \mu \mathrm{g} / \mathrm{mL}$ to $4 \mu \mathrm{g} / \mathrm{mL}$ in white, flat-bottomed 96-well plates and incubated for 18 hours. Spent media was removed and replaced with fresh broth containing 10\% Alamar Blue (AbD Serotec BUF012B). As per the manufacturer's instructions, the plates were read after 4 hours of incubation in a Biotek Spectrophotometer at 595nm. Cytotoxicity was expressed as percent viability and statistically analyzed using 2-tailed t tests on PASW SPSS software.

\section{Bio-assay Guided Fractionation}

The HPLC analysis was performed on a Thermo Spectra-System HPLC apparatus, using a reverse phase $\mathrm{C} 18$ column. The gradient system was phase $\mathrm{A}$ : $\mathrm{H}_{2} \mathrm{O}$; phase $\mathrm{B}$ : acetonitrile. Flow rate was $1 \mathrm{ml} / \mathrm{min}$. This procedure was used to analyze the methanolic crude extracts of $R$. canina galls and fruits.

The methanolic crude extract of $R$. canina galls was separated into four fractions using HPLC (liquid phase $=0 \%$ ACN: $100 \% \mathrm{H}_{2} \mathrm{O}$ to $100 \% \mathrm{ACN}: 0 \% \mathrm{H}_{2} \mathrm{O}$ ). Each fraction was reconstituted in DMSO at $50 \mathrm{~g} / \mathrm{ml}$ and tested against only the bacteria that were inhibited in previous assays. Further spectroscopic analyses were conducted using 
HPLC/UV/ESI-MSn with positive and negative ESI (ThermoFinnigan LCQ with electrospray ionization). The HPLC (Agilent 1100 series binary pump) was run with a Waters XTerra MS C18 column with a Phenomenex C18 guard column (2x4mm). The mobile phase was A: $0.2 \%$ acetic acid in $\mathrm{H}_{2} \mathrm{O} ; \mathrm{B}: 0.2 \%$ acetic acid in Methanol. For ion detections, an Agilent 1100 G1314A UV/V was used with wavelengths at 254 and $280 \mathrm{~nm}$. After chemical analyses determined that the major constituent peak of the third fraction was ellagic acid, and the third fraction was consistently inhibiting the bacteria, another assay using pure ellagic acid (Sigma-Aldrich E2250) was conducted to determine the MICs of the pure compound. Ellagic acid precipitated into crystal form in aqueous broths but dissolved with slight heating.

\section{RESULTS}

\section{Antibacterial Assay}

The first anti-bacterial assay showed that $R$. canina gall methanolic extracts inhibited six bacteria (E. coli, P. aeruginosa, S. enteriditis, Vibrio cholerae, Staphylococcus aureus, and Enterococcus faecalis) at low concentrations (Figure 5.1). Clinical variants of these bacteria are antibiotic resistant. 
Figure 5.1 MIC's ( $\mu \mathrm{g} / \mathrm{mL})$ of Rose Galls against Bacteria from First Bioassay

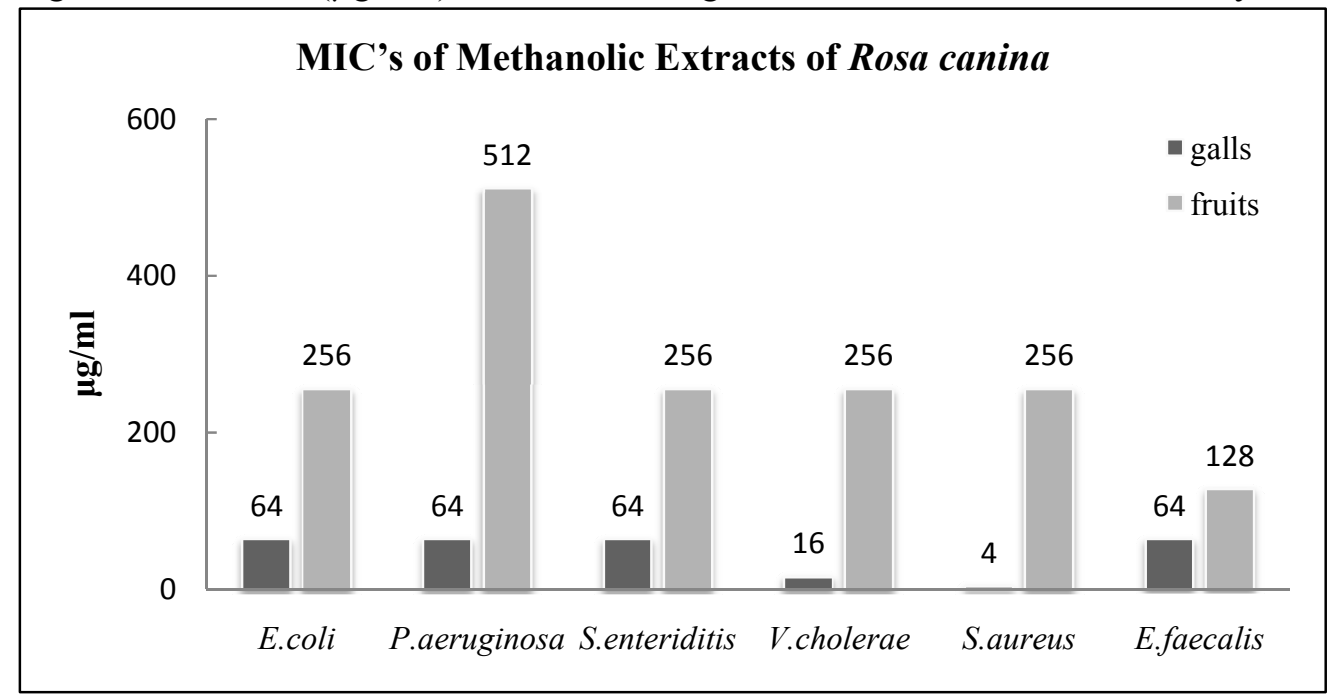

In the second bioassay, $R$. canina galls and fruits inhibited fourteen strains of bacteria (Table 5.1). Pseudomonas aeruginosa was the most sensitive to methanolic rose gall extracts at $4 \mu \mathrm{g} / \mathrm{ml} \mathrm{MIC}$, and $S$. flexneri was inhibited at $8 \mu \mathrm{g} / \mathrm{ml}$. Vibrio parahaemolyticus also was sensitive to methanolic rosehip extracts $(32 \mu \mathrm{g} / \mathrm{ml} \mathrm{MIC})$ and methanolic rose gall extracts $(16 \mu \mathrm{g} / \mathrm{ml} \mathrm{MIC})$. Methanolic extracts also showed inhibition against L. monocytogenes (rosehips at $128 \mu \mathrm{g} / \mathrm{ml} \mathrm{MIC}$ and galls at $64 \mu \mathrm{g} / \mathrm{ml} \mathrm{MIC)}$ ). Enterococcus faecalis and S. enterica typhimurium were inhibited at $32 \mu \mathrm{g} / \mathrm{ml}$. Other bacteria were inhibited at concentrations of $64 \mu \mathrm{g} / \mathrm{ml}$ or above. 
Table 5.1 Secondary assay MICs $(\mu \mathrm{g} / \mathrm{mL})$ of Rosa canina fruit and gall extracts

\begin{tabular}{|l|c|c|c|c|c|c|c|c|c|c|c|c|c|c|}
\hline \multirow{2}{*}{ Extract } & \multicolumn{10}{|c|}{ Bacterial Pathogens } \\
\cline { 2 - 15 }$y$ & Bs & Ec & Ef & Kp & Lm & Pa & Se & St & Sa & Sf & Ss & Vp & Ye & Yu \\
\hline RoCF met & 128 & 512 & & & 128 & & & & & & 512 & 32 & & 64 \\
\hline RoCF aq & & & & & & & & & & & & & & 256 \\
\hline RoCG met & 256 & 64 & 32 & 256 & 64 & 4 & 128 & 32 & 256 & 8 & 256 & 16 & 256 & 64 \\
\hline
\end{tabular}

Blank cells denote no inhibition.

RoCF=Rosa canina Fruits, RoCG=Rosa canina Galls; met=methanolic, aq=aqueous

Bacteria coded: $\mathrm{Bs}=$ Bacillus subtilis; $\mathrm{Ec}=$ Escherichica coli; $\mathrm{Ef}=$ Enterococcus faecalis; $\mathrm{Kp}=$ Klebsiells

pneumoniae; $\mathrm{Lm}=$ Listeria monocytogenes; $\mathrm{Pa}=$ Pseudomonas aeruginosa $; \mathrm{Se}=$ Salmonella enterica $; \mathrm{St}=S$.

enterica typhimurium; $\mathrm{Sa}=$ Staphylococcus aureus; $\mathrm{Sf}=$ Shigella flexneri; $\mathrm{Ss}=$ Shigella sonnei; $\mathrm{V}$ =Vibrio

parahaemolyticus; $\mathrm{Ye}=$ Yersinia enterocoliticus; $\mathrm{Yu}=$ Y. pseudotuberculosis

\section{Cytotoxicity Assay}

In the preliminary Alamar Blue assay, methanolic extracts of R.canina galls showed cytotoxicity of the prostate cell line at $50 \mu \mathrm{g} / \mathrm{ml}$ and of the skin melanoma cell line at $100 \mu \mathrm{g} / \mathrm{ml}$. There was no cytotoxicity indicated for the hepatic HepG-2 cell line.

Camptothecin showed toxicity in all cell lines at $5 \mu \mathrm{g} / \mathrm{ml}$. Considering the liver is the site for foreign chemical reduction and neutralization in the human body, inhibition of HepG2 was considered a better indicator of cytotoxicity after ingestion of plant materials than inhibition of Sk-Mel or PC-3 cell lines.

Further evaluation of cytotoxic activity showed that aqueous and methanolic extracts of $R$. canina did not significantly inhibit human cell-line growth. The optical density (OD) readings for cell lines with $R$. canina extracts showed higher metabolic rates because of the growth and increase of cells. Therefore, after cytotoxicity assays, the $R$. canina extracts were considered ideal for further evaluation of their bacterial inhibition properties. 


\section{Bio-assay Guided Fractionation}

Several peaks were seen in the HPLC of the $R$. canina gall methanolic extract. The peak at 29.562 min predominated the composition of the extract (Figure 5.2). The methanolic crude extract of $R$. canina galls was split into four fractions, with the first the most hydrophilic and the last the most hydrophobic. The third fraction showed inhibition in the repeated bioassays and was considered to hold the active component.

Figure 5.2 HPLC chromatogram of the methanolic $R$. canina gall extract

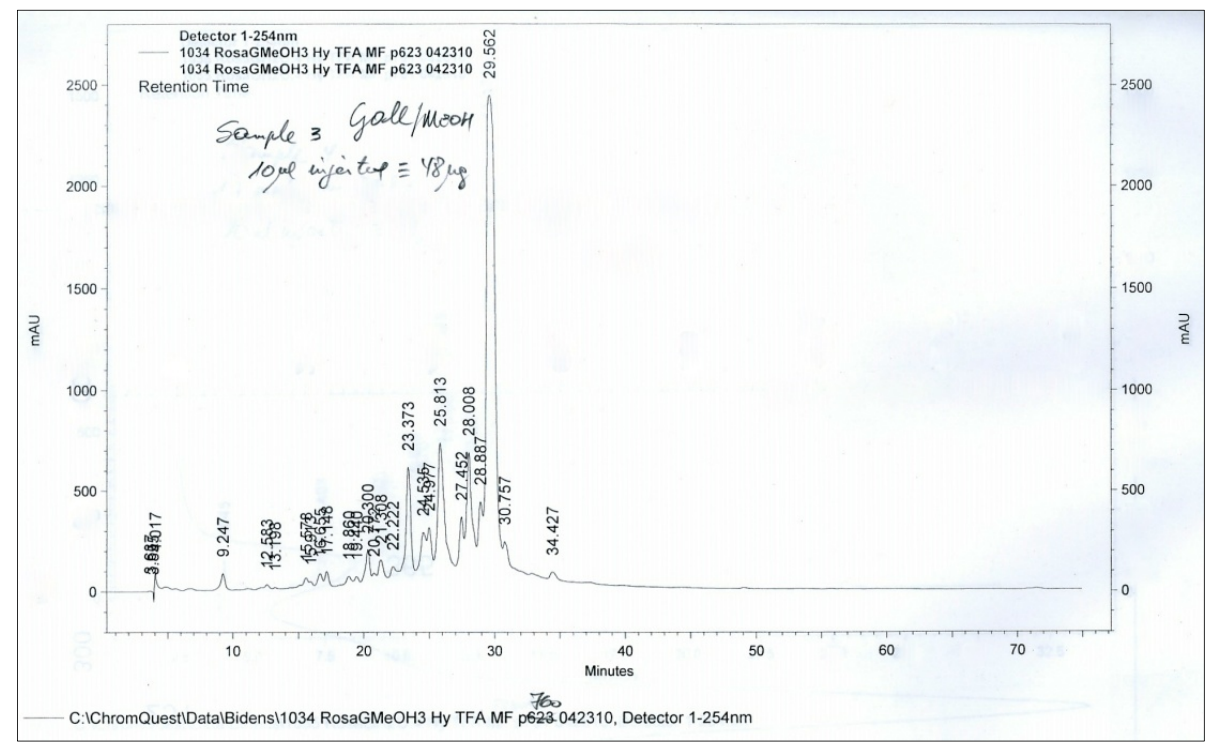

Fraction 3, which correlated with the peak retention time of $29.562 \mathrm{~min}$. in the initial chromatogram, was further analyzed by HPLC/UV/ESI-MSn. A compound of molecular weight (MW) 302 was most abundant, with minor amounts of MW 434 and 464 monoglycosides of the MW 302 aglycone. Other compounds included larger compounds (MW 788, 936, and 1118) which most likely correlate with glycosides of gallic acid or ellagic acid, and might be gallotannins or ellagitannins. With UV analysis, ions characteristic of ellagic acid (Figure 5.3) were identified (m/z 284, 257, 229, 201, 
and 185). The (-)ESI-MS/MS spectra did not match quercetin (MW 302.25), hesperetin (MW 302), morin (MW 302.25), or homoeriodictyol spectra (MW 302.29). Ellagic acid is a polyphenolic compound. Its molecular formula is $\mathrm{C}_{14} \mathrm{H}_{6} \mathrm{O}_{8}, \mathrm{MW} 302$, with IUPAC name 2,3,7,8-Tetrahydroxy-chromeno [5,4,3-cde]chromene-5, 10-dione.

Figure 5.3 Chemical structure of ellagic acid<smiles>O=c1oc2c(O)c(O)cc3c(=O)oc4c(O)c(O)cc1c4c23</smiles>

After ellagic acid was determined by MS-ESI, the bioassay was repeated using an ellagic acid standard (Table 5.2). Escherichia coli $\mathrm{Nat} \mathrm{OH} 5$ alpha and Y. enterocolitica O18 8081v with pYv were inhibited by ellagic acid at $\mathrm{MIC}_{50} 32 \mu \mathrm{g} / \mathrm{ml}$. Yersinia enterocolitica $8081 \mathrm{c}$ without pYv was minimally inhibited by ellagic acid, as was the case with $R$. canina extracts. At $64 \mu \mathrm{g} / \mathrm{ml}$, L. monocytogenes (ATCC19015) was inhibited more than $50 \%$, as was $Y$. pseudotuberculosis III YP KmR. The PA 01 strain of $P$. aeruginosa showed $\mathrm{MIC}_{90}$ of $256 \mu \mathrm{g} / \mathrm{ml}$ and $\mathrm{MIC}_{50}$ of $8 \mu \mathrm{g} / \mathrm{ml}$, a concentration that is low enough to be considered for clinical medications. Several bacterial strains were inhibited at $8 \mu \mathrm{g} / \mathrm{ml}$, including $S$. aureus (ATCC 29213) with an average percent inhibition of $78.5 \%, V$. parahaemolyticus (ATCC 17802) with an average $75.9 \%$ inhibition, and $S$. flexneri (ATCC 9199) with an average 78.8\% inhibition. The closely related S. sonnei (ATCC 25931), which often is less virulent than S. flexneri, was not inhibited by the ellagic acid except at high concentrations $(512 \mu \mathrm{g} / \mathrm{ml})$. 
Table 5.2 Bioassay Results $(\mu \mathrm{g} / \mathrm{ml})$ using Standard Ellagic acid

\begin{tabular}{|c|c|c|c|}
\hline \multirow{13}{*}{ 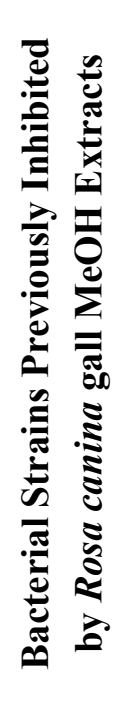 } & \multicolumn{3}{|c|}{ Pure Ellagic Acid MICs } \\
\hline & & $\mathrm{MIC}_{90}$ & $\mathrm{MIC}_{50}$ \\
\hline & Ec-0 & 512 & 32 \\
\hline & Lm-2 & 128 & 64 \\
\hline & Pa-1 & 256 & 8 \\
\hline & Sa-4 & 256 & $<8$ \\
\hline & Sf-1 & 16 & $<8$ \\
\hline & Ss-1 & 512 & - \\
\hline & St-4 & 512 & 128 \\
\hline & Vp-1 & 16 & $<8$ \\
\hline & Ye-1 & 512 & - \\
\hline & Ye-2 & 128 & 32 \\
\hline & Yu-1 & 128 & 64 \\
\hline
\end{tabular}

\section{DISCUSSION}

Ellagic acid explains inhibition of several diarrhea-causing bacteria in methanolic rose gall extract. Ellagic acid is a biphenyl lactone found in fruits and nuts, including fruits of the Rosaceae family such as strawberries, raspberries, and blackberries (Vattem and Shetty, 2005). Previous research has evaluated its antioxidant (Barch et al., 1995, Zhang et al., 1993), anti-carcinogenic (Chen et al., 2003, Kauer et al., 1997, Loarca-Pina et al., 1998, Narayanan et al., 1999, Teel et al., 1986), and anti-inflammatory properties (Gerritsen et al., 1995). With free radical scavenging, ellagic acid directly alleviates oxidative stress in cellular environments, but it can also stimulate cell pathways for reducing agents and increase antioxidant enzyme responses (Vattem and Shetty, 2005). As a biphenyl, ellagic acid is similar in structure to cell signaling molecules, is slightly hydrophobic and able to insert into lipid membranes, and acts as a chelator for sequestering metal ions (Vattem and Shetty 2005). 
As a weak acid, ellagic acid can disassociate cell membranes, disrupt electrostatic gradients, reconfigure membrane proteins and receptors, and interrupt cell functions such as motility, nutrient uptake, ATP generation, and basic metabolism (Vattem and Shetty, 2005). Researchers have investigated the antibacterial properties of ellagic acid against Staphylococcus aureus (Akiyama et al., 2001), in combination with clove compounds against oral pathogens such as Porphyromonas gingivalis, Streptococcus mutans, Actinomyces viscosus, and Prevotella intermedia (Cai and $\mathrm{Wu}, 1996$ ), and in synergistic combination with rosemary and cranberry compounds to prevent Helicobacter pylori urease activity (Lin et al., 2005) and to protect DNA from mutagenic toxins (Vattem et al., 2006). Like other polyphenolic compounds, ellagic acid increases the efficacy of other antioxidants synergistically (Shetty and Wahlqvist, 2004). Ellagic acid was found to significantly prevent biofilm formation of $E$. coli without any bactericidal activity (Hancock et al., 2010). When a proton from ellagic acid's carboxyl or hydroxyl groups acidifies the microenvironments of bacteria, the overall ion charge is altered, allowing partially hydrophobic ellagic acid to insert into bacterial membranes and reconfigure enzymes used for bacterial pathogenicity such as urease (Lin et al., 2005).

Previous chemical research on rose galls has investigated the nutritional properties of the galls with respect to the needs of growing larvae (Hartley and Lawton, 1992, St. John and Shorthouse, 2000) and possible hormonal changes in the galls when compared to non-galled tissues (Schönrogge et al., 1998). A chemical analysis that focuses on medicinal, antibacterial properties of rose galls logically focuses on plant defense compounds. Injury to a plant leads to up-regulation of defense chemicals, known as the Hypersensitivity Response (HR). After trauma induces HR, secondary pathways might lead to Induced Systemic Resistance (ISR), which is a response to insect or herbivore 
damage. Microbes initiate the Hypersensitivity Response HR and later induce the host's Systemic Acquired Resistance (SAR).

Derived from the shikimate and acetate-malonate biosynthetic pathways (Strack, 1997), ellagic acid is commonly elicited by SAR, or the microbe-induced response. Yet, in a gall, an insect is supposedly initiating the plant response. The rose might produce ellagic acid to prevent bacterial infection, even though Diplolepis wasps maintain a sterile gall environment (Randolph, 2005) by ovipositing and hatching between plant cells and delaying defecation until just before pupation in the spring. Randolph (2005) and Shorthouse (2005) postulate that there is a microbe in the egg, larva, or ovipositor of the female wasp which induces changes in plant phenolic compound production. Bacterial infection of wasps is exemplified in Wolbachia-induced parthenogenesis (Plantard, 1999), as females predominate the population.

Oak leaves with cynipid wasp galls have increased levels of tannins correlated with higher species diversity and abundance of wasps (Taper and Case, 1987). Tannins were hypothesized to protect cynipid larvae from fungal attack. More recent research found that concentrations of phenolic compounds, including tannins, increased in Cecidomyiidae galled leaves, and this prevented foliverous insects from eating the leaves later in the season (Pascual-Alvarado, et al., 2008). Tannins are closely related to ellagic acid, which forms hydrolysable ester bonds with glucosides in plant tissues, forming complex ellagitannins.

A possible explanation for ellagic acid production in response to galls is the control for oxidative stress from larvae chewing through cells while maintaining photosynthetic rates. In Brazil, researchers found decreased concentrations of chlorophylls and carotenoids in galled tissues but increased numbers of plastoglobules, 
allowing for thylakoid membrane recovery and maintenance of comparable maximum

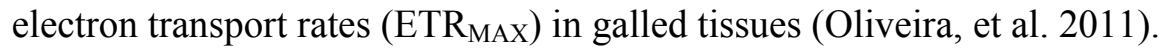

Cynipid Andricus palustris wasp galls alter the composition and distribution of two types of host plant cell membrane lipids - glycerolipids and phosphoglycerides (Bayer, 1994). Since polyphenolic compounds like ellagic acid are able to acidify cellular environments, alter electrochemical gradients, and embed within lipid membranes, perhaps ellagic acid functions as a signal or regulator for nutrient sink activities in the galled host tissues while also preventing infection or herbivory. Ellagic acid can prevent tumorigenic, mutagenic, and carcinogenic activity in human cells, and might be used in a similar manner in plant cells.

Better understanding the functions and properties of plant chemicals in their original plant cell environment and later in the human (or other herbivore) body would facilitate medicinal research on beneficial phytochemicals. Whether ellagic acid production in rose galls is induced by an insect, an unknown microbe, or the innate plant defense response, it has multiple potential benefits for treating and preventing human infectious disease as well as plant pathogens and herbivory. Gall ecology might also be used to increase desirable compounds for the biopharmaceutical or herbal supplement industry. 


\section{CONCLUSIONS}

Rosa canina galls are used in decoctions to treat gastrointestinal illness and diarrhea in Central Anatolian villages. While rosehips are a common medicinal remedy for a variety of ailments, the galls of the rosehips are not used as often. After evaluation in antibacterial bioassays involving 10 and 21 bacteria and a cytotoxicity screening, the methanolic extracts of $R$. canina galls, and not rosehips, were able to significantly inhibit bacterial growth in B. subtilis, E. coli, P. aeruginosa, S. aureus, S. flexneri, S. enterica typhimurium, V. cholerae, V. parahaemolyticus, and $Y$. enterocolitica.

Using bioassay-guided fractionation techniques, an antibacterial fraction was identified and found to be primarily composed of ellagic acid when analyzed by ESI-MS. The bioassay was performed again with $100 \%$ ellagic acid against previously inhibited bacteria, with comparable results to the MIC's of the methanolic extract of $R$. canina galls. Bacteria that were highly inhibited by ellagic acid (at $8 \mu \mathrm{g} / \mathrm{ml}$ or lower $\mathrm{MIC}_{50}$ 's) included $V$. parahaemolyticus, $P$. aeruginosa, L. monocytogenes, and $S$. aureus.

The preceding laboratory research was the culmination of a process of ethnobotanical inquiry. Such techniques are promising for the discovery of effective, safe plants that can be used to treat bacterial infectious diseases forthright, or with chemical isolation and manipulation after overarching mechanisms of action are described.

Future research with $R$. canina galls will involve further evaluation of the biochemistry of the galls and fruits to better understand the intricate relationships between cynipid wasps, roses, and possible microbes. How these relationships induce defensive chemicals, or phytoalexins, that are inhibitory of bacterial growth should be further investigated, along with the in vivo functions of ellagic acid within plants. 


\section{ACKNOWLEDGMENTS}

I received funding from the J. William Fulbright Foreign Scholarship Award, the Turkish Fulbright Commission, an NIH MBRS/RISE fellowship, and a Summer Biomedical Research Initiative (NIH NIGMS R25 GM 061347) through FIU in order to complete my doctoral research. Horacio Priestap offered guidance and assisted with chemical analyses, as did John Berry. Jodie Johnson facilitated the use of the HPLC/UV/ESI-MSn equipment at the University of Florida. Use of laboratory space and equipment was granted by the Center for Ethnobiology and Natural Products at FIU.

\section{REFERENCES}

Akiyama, H., Fujii, K., Yamasaki, O., Oono, T., and Iwatsuki, K., 2001. Antibacterial action of several tannins against Staphylococcus aureus. Journal of Antimicrobial Chemotherapy. 48, 487-491.

Barch, D. H., Rundhaugen, L. M., and Pillay, N. S., 1995. Ellagic acid Induces Transcription of the Rat Glutathione S-transferase-Ya Gene. Carcinogenesis. 16, 665-668.

Barrett, J. D., Clarke, P. V., Richardson, D. H. S., 1998. The in vitro culture of rose-gall tissue induced by the cynipid was Diplolepis spinosa (Ashmead). Symbiosis. 25, 229-236.

Barry, A., Craig, W., Nadler, N., Reller, L. B., Sanders, C., Swenson, J., 1999. M26-A, Methods for Determining Bactericidal Activity of Antimicrobial Agents; Approved Guideline. NCCLS Catalog, now Clinical and Laboratory Standards Institute (CLSI), 19(18), 1-30.

Bayer, M. H., 1994. Biochemical modification of the phenotype in cynipid galls: cell membrane lipids, in: Williams, M. (Ed.), Plant Galls. Clarendon Press, Oxford, pp. 429446.

Cai, L., Wu, C., 1996. Compounds from Syzygium aromaticum Possessing Growth Inhibitory Activity against Oral Pathogens. Journal of Natural Products. 59, 987-990.

Chen, C., Shen,G., Hebbar, V., Hu, R., Owuor, E. D., Kong, A. N., 2003. Epigallocatechin-3-gallate-induced Stress Signals in HT-29 Human Colon Adenocarcinoma Cells. Carcinogenesis. 24, 1369-1378. 
Gerritsen, M. E., Carley, W. W., Ranges, G. E., Chien-Ping, S., Phan, S. A., Ligon, G. F., Perry, C. A., 1995. Flavonoids inhibit cytokine-induced endothelial cell adhesion protein gene expression. American Journal of Pathology. 147, 278-292.

Güçlü, S., Hayat, R., Shorthouse, J., Tozlu, G., 2008. Gall-inducing Wasps of the Genus Diplolepis (Hymenoptera: Cynipidae) on Shrub Roses of Turkey. Proceedings of the Entomological Society of Washington. 110, no. 1, 204-217.

Hancock, V., Dahl, M., Vejborg R. M., Klemm, P., 2010. Dietary plant components ellagic acid and tannic acid inhibit Escherichia coli biofilm formation. Journal of Medical Microbiology. 59, 496-498.

Hartley, S. E., Lawton, J. H., 1992. Host-plant manipulation by gall-insects - A test of the nutrition hypothesis. Journal of Animal Ecology. 61, 113-119.

Kauer, S., Grover, I. S., Kumar, S., 1997. Antimutagenic Potential of Ellagic Acid Isolated from Terminalia arjuna. Indian Journal of Experimental Biology. 35, 478-482.

Krussmann, G., 1982. Roses. English Edition. B. T. Batsford, London.

Lin, Y. T., Kwon, Y. I., Labbe, R. G., Shetty, K., 2005. Inhibition of Helicobacter pylori and Associated Urease by Oregano and Cranberry Phytochemical Synergies. Applied and Environmental Microbiology. 71, no. 12, 8558-8564.

Loarca-Pina, G., Kuzmicky, P.A., De Mejia, E. G., Kado, N. Y., 1998. Inhibitory Effects of Ellagic Acid on the Direct-acting Mutagenicity of Aflatoxin B1 in the Salmonella Microsuspenstion Assay. Mutation Research. 398, no. 1-2, 183-187.

Narayanan, B., Geoffroy, O., Willingham, M., Re, G., Nixon, D., 1999.

p53/p21(WAF1/CIP1) expression and its possible role in G1 arrest and apoptosis in ellagic acid treated cancer cells. Cancer Letters. 136, 215-221.

O'Brien, J., Wilson, I., Orton, T., Pognan, F., 2000. Investigation of the Alamar Blue (resazurin) fluorescent dye for the assessment of mammalian cell cytotoxicity. European Journal of Biochemistry. 267, no. 17, 5421-5426.

Oliveira, D. C. de, Santos Isaias, R. M. dos, Moreira, A. S. F. P., Magalhães, T. A., Lemos-Filho, J. P. de, 2011. Is the oxidative stress caused by Aspidosperma spp. galls capable of altering leaf photosynthesis? Plant Science. 180, 489-495. 
Orhan, D. D., Hartevioalu, A., Kupeli, E., Yeşilada, E., 2007. In vivo anti-inflammatory and antinociceptive activity of the crude extract and fractions from Rosa canina L. fruits. Journal of Ethnopharmacology. 112, no. 2, 394-400.

Pascual-Alvarado, E., Cuevas-Reyes, P., Quesada, M., Oyama, K., 2008. Interactions between galling insects and leaf-feeding insects: the role of plant phenolic compounds and their possible interference with herbivores. Journal of Tropical Ecology. 24, 329-336.

Plantard, O., Rasplus, J. Y., Mondor, G. Le, Clainche, I., Solignac, M., 1999. Distribution and phylogeny of Wolbachia inducing thelytoky in 'Rhoditini' and 'Aylacini' (Hemenoptera: Cynipidae). Insect Molecular Biology. 8, 185-191.

Randolph, S., 2005. The Natural History of the Rose Bedeguar Gall and its Insect Community. The British Plant Gall Society, Suffolk.

Redfern, M., Shirley, P., 2002. British Plant Galls: Identification of Galls on Plants and Fungi. Field Studies. 10, 207-531.

Schönrogge, K., Harper, L. J., Brooks, S. E., Shorthouse, J. D., Lichtenstein, C. P., 1998. Reprogramming plant development: Two approaches to study the molecular mechanism of gall formation, in: Csoka, G., Mattson, W. J., Stone, G. N., Price, P. W. (Eds.), Biology of Gall-Inducing Arthropods. US Department of Agriculture, Forest Service, St. Paul, MN, pp. 153-160.

Sezik, E., Yeşilada, E., Honda, G., Takaishi, Y., Takeda, Y., Tanaka, T., 2001. Traditional Medicine in Turkey X. Folk Medicine in Central Anatolia. Journal of Ethnopharmacology 75, 95-115.

Shetty, K., Wahlqvist, M.L., 2004. A Model for the Role of Proline-linked Pentose Phosphate Pathway in Phenolic Phytochemical Biosynthesis and Mechanism of Action for Human Health and Environmental Applications. Asia Pacific Journal of Clinical Nutrition. 13, 1-24.

Shorthouse, J., 2005. Foreword, in: Randolph, S., The Natural History of the Rose Bedeguar Gall and its Insect Community, The British Plant Gall Society, Suffolk, pp. 5-7.

St. John, M. G., and Shorthouse, J. D., 2000. Allocation Patterns of Organic Nitrogen and Mineral Nutrients within Stem Galls of Diplolepis spinosa and Diplolepis triforma (Hymenoptera: Cynipidae) on Wild Roses (Rosaceae). Canadian Entomologist. 132, 635648. 
Strack, D., 1997. Phenolic Metabolism, in: Dey, P. M., Harborne, J. B. (Eds.), Plant Biochemistry, Academic Press, San Diego, CA, pp. 387-416.

Taper, M. L., Case, T. J., 1987. Interactions between oak tannins and parasite community structure: Unexpected benefits of tannins to cynipid gall-wasps. Oecologia. 71, 254-261.

Teel, R., Babcock, M., Dixit, R., Stone, G., 1986. Ellagic acid toxicity and interaction with Benzo[A]pyrene and Benzo[A]pyrene 7,8-dihydrodiol in human bronchial epithelial cells. Cell Biology and Toxicology. 2, no. 1, 53-62.

The Ministry of Health of Turkey, 2004. Turkey Health Report. The Ministry of Health of Turkey (Türkiye Cumhuriyeti Sağlık Bakanlığı) and The School of Public Health (Refik Saydam Hıfzıssıhha Mektebi Müdürlüğü), Ankara.

Tuzlac1, E., Aymaz, P. E., 2001. Turkish Folk Medicinal Plants, Part IV: Gonen (Balikesir). Fitoterapia. 72, 323-343.

Vattem, D. A., Shetty, K., 2005. Biological Funcionality of Ellagic Acid: A Review. Journal of Food Biochemistry. 29, 234-266.

Vattem, D. A., Jang, H. D., Levin, R., Shetty, K., 2006. Synergism of Cranberry Phenolics with Ellagic Acid and Rosmarinic Acid for Antimutagenic and DNA Protection Functions. Journal of Food Biochemistry. 30, 98-116.

WHO and UNICEF. 2004. Clinical Management of Acute Diarrhoea:

WHO/FCH/CAH/04.7. World Health Organization and United Nations' Children's Fund, Geneva.

WHO. 2009. Diarrhoeal Diseases. World Health Organization, Geneva.

Yeşilada, E., Honda, G., Sezik, E., Tabata, M., Takeda, Y., 1995. Traditional Medicine in Turkey. V. Folk Medicine in the Inner Taurus Mountains. Journal of Ethnopharmacology. 46, 133-152.

Yeşilada, E., Gürbüz, İ., Shibata, H., 1999. Screening of Turkish anti-ulcerogenic folk remedies for anti-Helicobacter pylori activity. Journal of Ethnopharmacology. 66, no. 3, 289-293.

Zhang, Z., Hamilton, S. M., Stewart, C., Strother, A., Teel, R. W., 1993. Inhibition of Liver Microsomal Cytochrome P450 Activity and Metabolism of the Tobacco-specific Nitrosamine NNK by Capsaicin and Ellagic acid. Anticancer Research. 13, no. 6a, 23412346. 


\section{APPENDICES}

TITLE

PAGE

1. Survey Instrument in Turkish 115

2. Survey Instrument Back-translated into English 117

3. Literature Review Results for Turkish Anti-Diarrheal Plants 119

4. Antibacterial Activity of Extracts (1-34) and Controls 130 
Appendix 1: Survey Instrument in Turkish
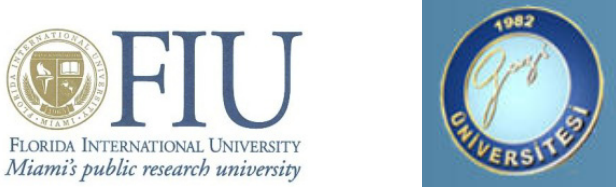

Türkiye' de ishal için kullanilan bitkisel

Merhaba. Bize yardim ettiginiz için çok tesekkür ederiz. Biz Ankara Gazi Üniversitesi'nde ögrenciyiz. Bu bilgiyi okul kimliklerimizden kontrol edebilirsiniz. Lütfen asagidaki sorulara sizin için uygun olan cevabi veriniz. Sizden herhangi bir kimlik bilgisi istemiyoruz. Sadece düsüncelerinizi yazmanizi istiyoruz.

Yasiniz:

Cinsiyetiniz:

Memleketiniz:

Medeni Haliniz: Evli Bekâr Bosanmis Dul Diger

Mesleginiz:

Çocuklariniz var mi? Evet Hayir

Torunlariniz var mi? Evet Hayir

Kaç senedir burada yasiyorsunuz?

Buradan önce baska bir yerde yasadiniz mi?

Eger yanitiniz evetse kaç yil baska yerde yasadiginizi belirtiniz.

Etnik kökeniniz nedir?

Çalisma alanimiz Türkiye' de ishal için kullanilan bitkisel tedavi yöntemleri ve diger dogal yöntemlerle ilgili uygulamalar. Asagidaki sorulari cevaplarsaniz çok seviniriz.

1. "Ishal" disinda bu hastalik için kullandiginiz baska sözcükler var mi? Varsa neler?

2. Sizce neden insanlar ishal olur?

3. Bildiginiz ishal çesitleri var mi? Varsa bu farklari belirtebiliri misiniz?

4. Daha önce ishal tedavisi için hiç bitkisel ya da dogal baska bir yönteme basvurdunuz mu?

Cevabiniz "hayir"sa anketimiz burada bitmistir. Tesekkür ederiz.

5. Ishal tedavisinde kullandiginiz bitki ve yiyecekleri nelerdir?

6. Sizce ishale en iyi gelen bitki nedir?

7. Bu bitkiye kolaylikla ulasabiliyor musunuz? Ulasamiyorsaniz ikinci tercihiniz nedir? 
8. Bu bitkinin ishale iyi geldigini nereden ögrendiniz? (büyüklerinizden, annenizden, babanizdan, dergilerden, televizyondan, diger)

9. Ishal hakkinda bildiklerinizi baskalarina da anlatiyor musunuz? (Örnegin:

Komsunuzun

çocugu hasta olsa ona da bunu tavsiye eder misiniz?) Yanitiniz evetse bunu en çok nerelerde

kullaniyorsunuz.

10. Bu bitkileri kendiniz mi topluyorsunuz?

Yanitiniz hayirsa lütfen 18. Soruya geçiniz. Evetse 11. soruyla devam ediniz.

11. Hangi bitkileri topluyorsunuz?

12. Bitki toplamaya tek basiniza mi yoksa grup halinde mi gidiyorsunuz?

Birileriyle birlikte gidiyorsaniz kimlerle gittiginizi belirtiniz.

13. Genellikle bu bitkileri toplamak için nereye gidersiniz?

14. Yilin hangi zamani bu bitkileri toplarsiniz?

15. Bitkinin hangi parçasini toplarsiniz?

16. Topladiginiz bitkileri nasil saklarsiniz. (Kurutarak, asarak, konserve yaparak diger)

17. Topladiklarinizi kimler kullanir. (müsteriler, aile vs)

18. Eger kullanacaginiz bitkiyi kendiniz toplamiyorsaniz nereden elde edersiniz? (arkadaslardan, aktardan, diger)

19. Bitkiyi tedavi amaçli kullanima nasil hazirliyorsunuz? (kaynatarak, pisirerek vs)

20. Ilaci hazirlarken ne kadar bitki kullaniyorsunuz?

21. Hasta kisi bu tedaviyi ne kadar zaman uygulamali?

22. Hiç bu konuda bir uzmana gider misiniz? Ne zaman?

23. Eger ishal hastasi bir çocugu ya da kendi çocugunuzu görürseniz tedavi olarak ne yaparsiniz?

24. Bir çocuga uyguladiginiz tedavi ile kendinize ya da daha yasli birisine uyguladiginiz tedavi arasinda bir fark var mi?

25. Bu konuda söylemek istediginiz baska bir seyler var mi?

Anketimiz bitti tesekkür ederiz. 
Appendix 2: Survey Instrument Back-translated into English
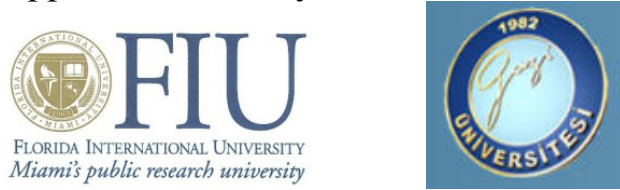

Hello. Thank you for assisting us in our research today. We are graduate students from Gazi University in Ankara, and we would like to ask you some questions. You may speak with us if you like, but you are under no obligation. Please feel free to ask us questions as well. Your answers will be recorded, but we will not record your name or any contact information so that you will remain anonymous in our research.

Age:

Nationality:

Village or Hometown:

Marital Status: Married Single Divorced Widowed Other

Occupation:

Do you have children? Yes No

Do you have grandchildren? Yes No

How long have you lived here?

If you've lived somewhere else, where was it?

If you've lived somewhere else, how many years were you there?

What ethnicity would you call yourself?

The following questions ask about herbal remedies used to treat diarrhea.

1. What is a common term you use for "diarrhea"? Do you use other names?

2. When someone you know gets diarrhea, what do you do?

3. Are there different kinds of diarrhea? What would they be?

4. Have you ever used a plant-based remedy to treat diarrhea?

If you answered "no" to question 4, then there are no more questions. Thank you for your time.

5. Which plants or foods do you use to treat diarrhea?

6. What is the best herb or food for treating diarrhea?

7. Is your favorite herb easy to obtain? If you can't find it, is there something else you use?

8. Where did you learn about these herbs? (books, your parents, your friends, TV, Other)

9. If you learn that a friend of yours has diarrhea, what would you advise? (Or, if one of your children is sick with diarrhea, what would you do?)

10. Do you collect anti-diarrheal plants?

If no, please skip to question 18. If yes, continue to question 11.

11. Which plants do you collect?

12. Do you collect these plants alone or in a group? With who would you go?

13. Generally, from where do you collect this plant? 
14. In what season do you collect it?

15. Which parts of the plant do you collect?

16. How do you store it once it's collected? (dry, cook, don't do anything to it)

17. Do you share the plant with anyone? (Neighbors, Family, etc...)

18. If you do not collect the plant yourself, from where do you get it? (Friends, Store, other...)

19. How do you prepare this plant if someone is sick with diarrhea? (steam, tea, etc...)

20. How much of the plant or its preparation do you give to the patient?

21. For how long do you give the plant or its preparation to the patient?

22. Do you ever go to the doctor to treat diarrhea? When?

23. If a child is sick with diarrhea, do they get sick in a different way?

24. Is a child given the same plants and doses?

25. Do you have anything else you'd like to add?

Thank you so much for your help. 
Appendix 3. Literature Review Results for Turkish Anti-Diarrheal Plants

\begin{tabular}{|c|c|c|c|c|c|c|}
\hline $\begin{array}{l}\text { Species } \\
\text { (Family) }\end{array}$ & $\begin{array}{l}\text { Common } \\
\text { name(s) }\end{array}$ & $\begin{array}{l}\text { Voucher } \\
\text { or Locale }\end{array}$ & $\begin{array}{l}\text { Part } \\
\text { Used }\end{array}$ & Preparation & Source & Area \\
\hline $\begin{array}{l}\text { Achillea millefolium } \mathrm{L} . \\
\text { (Asteraceae) }\end{array}$ & Amelotu & 13 & $\mathrm{Fl}$ & Diarrhea; Infusion, internal & $\begin{array}{l}\text { Yeşilada, et } \\
\text { al. } 1993\end{array}$ & Mediterranean \\
\hline $\begin{array}{l}\text { Achillea millefolium L. } \\
\text { ssp. millefolium } \\
\text { (Asteraceae) }\end{array}$ & $\begin{array}{l}\text { Akbaşotu, } \\
\text { Ayvadanası }\end{array}$ & 12 & $\mathrm{Hb}$ & $\begin{array}{l}\text { For abdominal pain, diarrhea, } \\
\text { eaten fresh or dried, decoction }\end{array}$ & $\begin{array}{l}\text { Honda, et al. } \\
1996\end{array}$ & West Anatolia \\
\hline $\begin{array}{l}\text { Adiantum capillus- } \\
\text { veneris } \mathrm{L} . \\
\quad \text { (Pteridaceae) }\end{array}$ & İshalotu & 8600049 & Lf & $\begin{array}{l}\text { Leaf pounded, mixed with flour, } \\
\text { given to calf for diarrhea }\end{array}$ & $\begin{array}{l}\text { Tabata et al, } \\
1988\end{array}$ & $\begin{array}{l}\text { Artvin, Borçka, } \\
\text { Muratlı }\end{array}$ \\
\hline $\begin{array}{l}\text { Ajuga chamaepitys (L.) } \\
\text { Schreb. ssp chia Arcang. } \\
\text { var. ciliata Banks \& Sol. } \\
\text { (Lamiaceae) }\end{array}$ & Kiraçotu & 25 & $\mathrm{Hb}$ & $\begin{array}{l}\text { For diarrhea, internal disease, } \\
\text { hemorrhoids, internal, decoction }\end{array}$ & $\begin{array}{l}\text { Yeşilada, et } \\
\text { al. } 1995\end{array}$ & $\begin{array}{l}\text { South Anatolia, } \\
\text { Taurus Mts }\end{array}$ \\
\hline $\begin{array}{l}\text { Asparagus acutifolius L. } \\
\text { (Asparagaceae) }\end{array}$ & Zamparna & 3 & $\mathrm{Rt}$ & $\begin{array}{l}\text { Dysentery, severe diarrhea; } \\
\text { Decoction, keep one night in } \\
\text { cool place, internal }\end{array}$ & $\begin{array}{l}\text { Yeşilada, et } \\
\text { al. } 1993\end{array}$ & Mediterranean \\
\hline $\begin{array}{l}\text { Bellis perennis L. } \\
\quad \text { (Asteraceae) }\end{array}$ & Koyun gözü & $24,30,43$ & $\mathrm{Fl}$ & $\begin{array}{l}\text { For diarrhea, as diuretic, } \\
\text { purgative, inf, internal }\end{array}$ & $\begin{array}{l}\text { Özgökçe \& } \\
\text { Özçelik } \\
2004\end{array}$ & East Anatolia \\
\hline $\begin{array}{l}\text { Camellia sinensis }(\mathrm{L} .) \\
\text { Kuntze } \\
\quad \text { (Theaceae) }\end{array}$ & Çay & 4,13 & Lf & $\begin{array}{l}\text { To stop diarrhea; a teaspoonful } \\
\text { of tea leaves is drunk }\end{array}$ & $\begin{array}{l}\text { Yeşilada, et } \\
\text { al. } 1999\end{array}$ & Northwest Anatolia \\
\hline
\end{tabular}




\begin{tabular}{|c|c|c|c|c|c|c|}
\hline $\begin{array}{l}\text { Camellia sinensis (L.) } \\
\text { Kuntze } \\
\quad \text { (Theaceae) }\end{array}$ & & 13 & $\mathrm{Lf}$ & $\begin{array}{l}\text { For diarrhea, pounded with } \\
\text { honey }\end{array}$ & $\begin{array}{l}\text { Yeşilada, et } \\
\text { al. } 1995\end{array}$ & $\begin{array}{l}\text { South Anatolia, } \\
\text { Taurus Mts }\end{array}$ \\
\hline $\begin{array}{l}\text { Camellia sinensis }(\mathrm{L} .) \\
\text { Kuntze } \\
\quad \text { (Theaceae) }\end{array}$ & Çay & 94407 & $\mathrm{Lf}$ & Powdered black tea leaves eaten & $\begin{array}{l}\text { Honda, et al. } \\
1996\end{array}$ & $\begin{array}{l}\text { Central Anatolia, } \\
\text { Kayseri, Akkışla, } \\
\text { Ortaköy }\end{array}$ \\
\hline $\begin{array}{l}\text { Capsella bursa-pastoris } \\
\text { (L.) Medik } \\
\text { (Brassicaceae) }\end{array}$ & Çobançantası & 513 & All & $\begin{array}{l}\text { For diarrhea (dysmenorrhea), } \\
\text { infusion, internal }\end{array}$ & $\begin{array}{l}\text { Aslan, et al. } \\
2007\end{array}$ & Izmir (Ödemiş) \\
\hline $\begin{array}{l}\text { Cedrus libani A. Rich. } \\
\text { (Pinaceae) }\end{array}$ & Sedir ağac1 & 9 & $\operatorname{Tr}$ & $\begin{array}{l}\text { For abdominal pain, diarrhea, } \\
\text { external poultice, internal, one } \\
\text { drop in glass of water }\end{array}$ & $\begin{array}{l}\text { Yeşilada, et } \\
\text { al. } 1995\end{array}$ & $\begin{array}{l}\text { South Anatolia, } \\
\text { Taurus Mts }\end{array}$ \\
\hline $\begin{array}{l}\text { Celtis australis L. } \\
\text { (Cannabaceae) }\end{array}$ & Kara çıtlık & 43 & $\begin{array}{l}\text { Fr, } \\
\mathrm{Lf}\end{array}$ & $\begin{array}{l}\text { For diarrhea, especially } \\
\text { children, decoction, eaten before } \\
\text { meals, internal }\end{array}$ & $\begin{array}{l}\text { Tuzlacı \& } \\
\text { Sadikoğlu } \\
2007\end{array}$ & Koçarlı (Aydın) \\
\hline $\begin{array}{l}\text { Centaurea cyanus L. } \\
\text { (Asteraceae) }\end{array}$ & $\begin{array}{l}\text { Mavi süpürge } \\
\text { çiçeği }\end{array}$ & & $\mathrm{Fl}$ & $\begin{array}{l}\text { For diarrhea, infusion } 3 \times 1 \text {, } \\
\text { internal }\end{array}$ & $\begin{array}{l}\text { Tuzlaci \& } \\
\text { Alparslan } \\
2007\end{array}$ & $\begin{array}{l}\text { Babaeski } \\
\text { (Kırklareli) }\end{array}$ \\
\hline $\begin{array}{l}\text { Centaurium erythraea } \\
\text { Rafn. ssp. turcicum } \\
\text { (Velen.) Melderis } \\
\quad \text { (Gentianaceae) }\end{array}$ & Kantariye & 54 & All & $\begin{array}{l}\text { For diarrhea, whole plant used } \\
\text { in decoction, internal }\end{array}$ & $\begin{array}{l}\text { Tuzlac1 \& } \\
\text { Tolon } 2000\end{array}$ & Şile (Istanbul) \\
\hline $\begin{array}{l}\text { Centaurium pulchellum } \\
\text { (Sw.) Druce } \\
\text { (Gentianaceae) }\end{array}$ & Kantaron & 54 & All & $\begin{array}{l}\text { For diarrhea, whole plant used } \\
\text { in decoction, internal }\end{array}$ & $\begin{array}{l}\text { Tuzlaci \& } \\
\text { Tolon } 2000\end{array}$ & Şile (Istanbul) \\
\hline
\end{tabular}




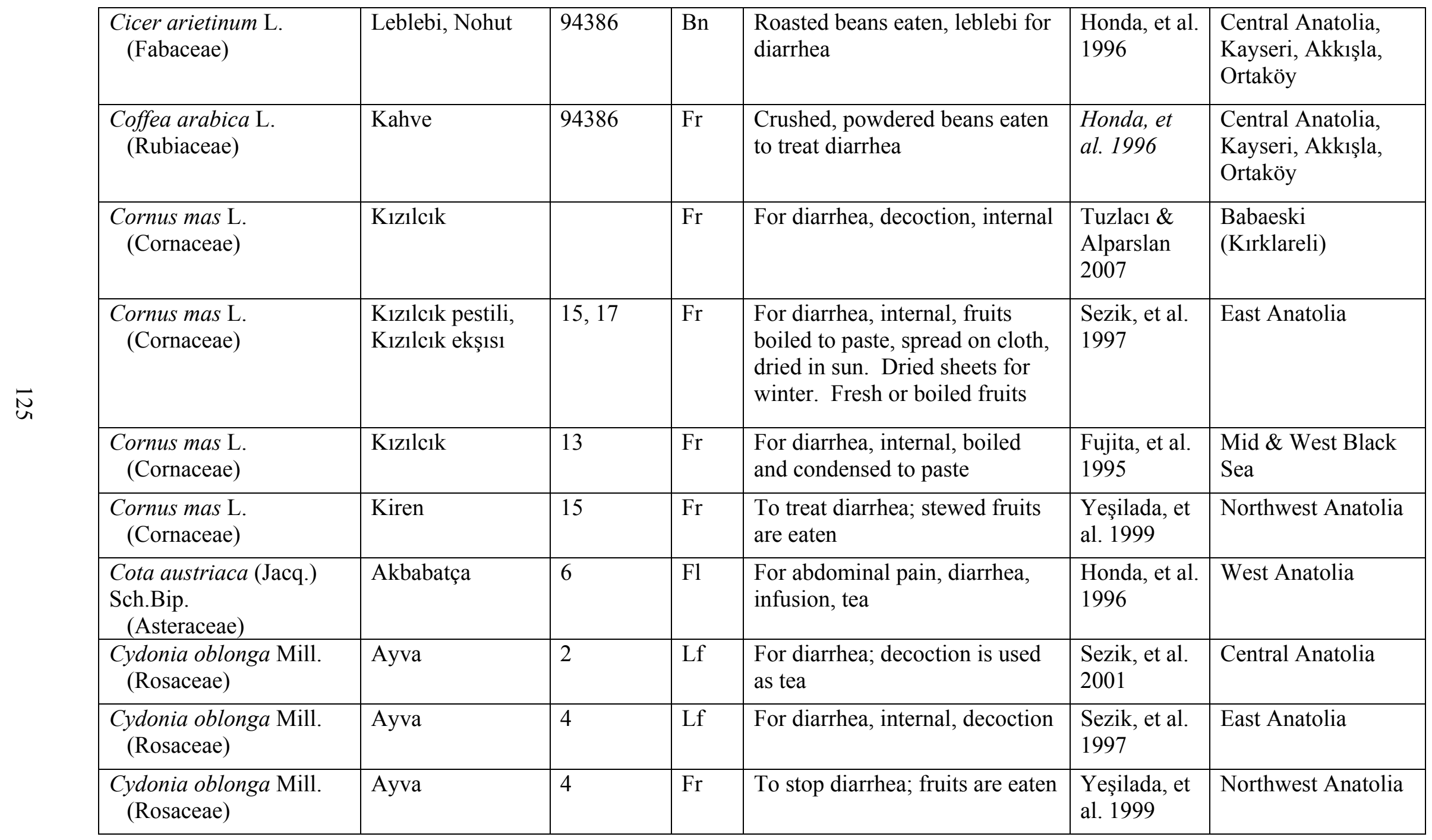




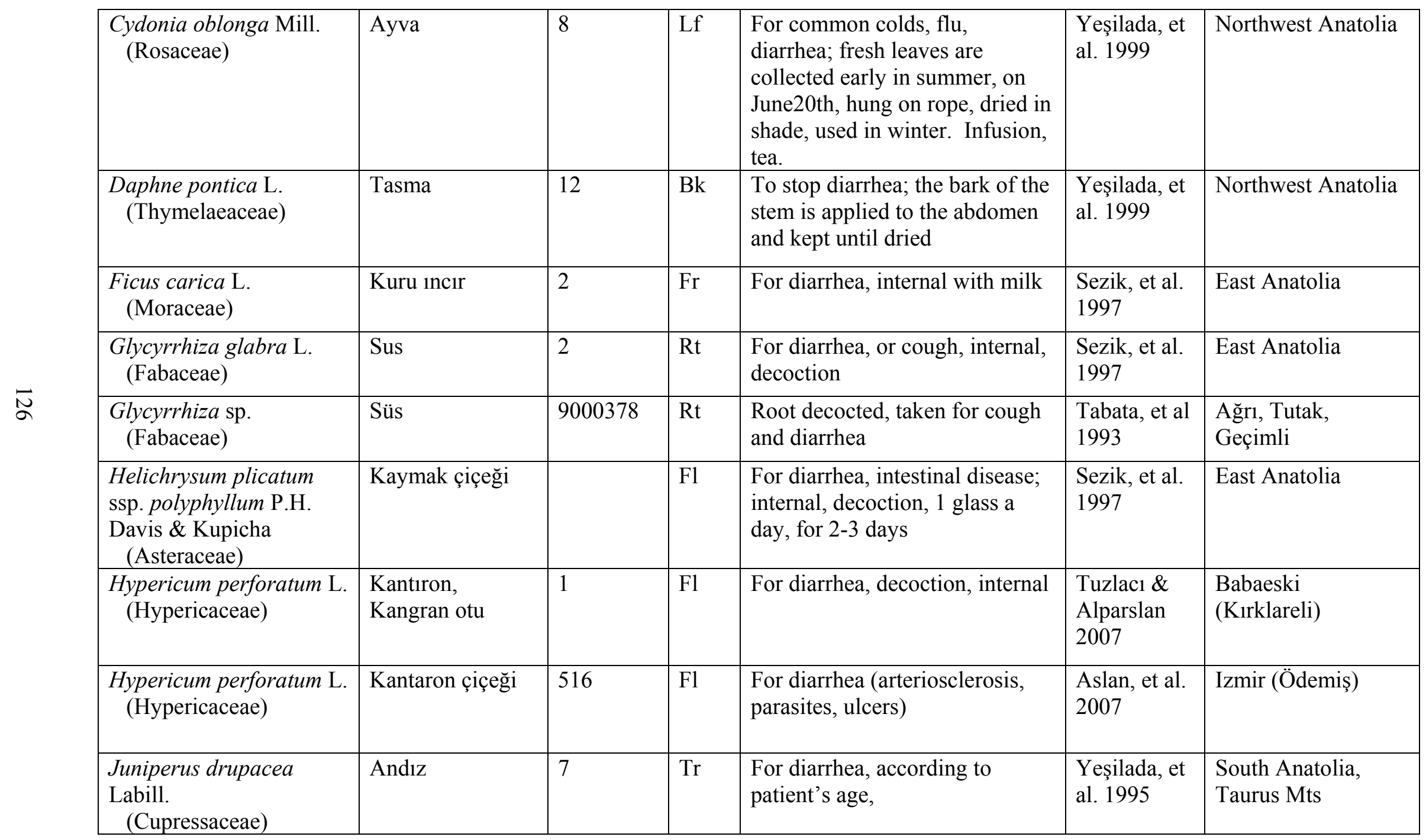




\begin{tabular}{|c|c|c|c|c|c|c|}
\hline $\begin{array}{l}\text { Lycopersicon esculentum } \\
\text { Mill. } \\
\text { (Solanaceae) }\end{array}$ & Domates & 94567 & $\mathrm{Fr}$ & $\begin{array}{l}\text { Fruit juice drunk to stop } \\
\text { diarrhea }\end{array}$ & $\begin{array}{l}\text { Honda, et al. } \\
1996\end{array}$ & $\begin{array}{l}\text { Central Anatolia, } \\
\text { Konya, Halkapınar, } \\
\text { Büyük Doğan }\end{array}$ \\
\hline $\begin{array}{l}\text { Mespilus germanica L. } \\
\quad \text { (Rosaceae) }\end{array}$ & & 22 & Fr & $\begin{array}{l}\text { For diarrhea; dried fruits are } \\
\text { eaten }\end{array}$ & $\begin{array}{l}\text { Yeşilada, et } \\
\text { al. } 1999\end{array}$ & Northwest Anatolia \\
\hline $\begin{array}{l}\text { Micromeria myrtifolia } \\
\text { Boiss. \& Hohen. } \\
\text { (Lamiaceae) }\end{array}$ & Amelotu & 537 & $\mathrm{Ae}$ & For diarrhea, infusion, internal & $\begin{array}{l}\text { Aslan, et al. } \\
2007\end{array}$ & Izmir (Ödemiş) \\
\hline $\begin{array}{l}\text { Papaver rhoeas L. } \\
\text { (Papaveraceae) }\end{array}$ & Gelincik & 1 & $\mathrm{Fl}$ & For diarrhea, infusion, internal & $\begin{array}{l}\text { Tuzlacı \& } \\
\text { Alparslan } \\
2007\end{array}$ & $\begin{array}{l}\text { Babaeski } \\
\text { (Kırklareli) }\end{array}$ \\
\hline $\begin{array}{l}\text { Papaver rhoeas L. } \\
\text { (Papaveraceae) }\end{array}$ & Gelincik & 22 & $\mathrm{Fl}$ & For diarrhea, infusion, internal & $\begin{array}{l}\text { Tuzlaci \& } \\
\text { Sadikoğlu } \\
2007\end{array}$ & Koçarlı (Aydın) \\
\hline $\begin{array}{l}\text { Pinus brutia Ten. } \\
\text { (Pinaceae) }\end{array}$ & Çam & 4 & Fr & $\begin{array}{l}\text { For diarrhea; decoction kept } \\
\text { overnight in cool place, internal }\end{array}$ & $\begin{array}{l}\text { Yeşilada, et } \\
\text { al. } 1993\end{array}$ & Mediterranean \\
\hline $\begin{array}{l}\text { Pinus brutia Ten. } \\
\text { (Pinaceae) }\end{array}$ & Çam & 10 & $\operatorname{Tr}$ & $\begin{array}{l}\text { For bloating and diarrhea; add } \\
\text { olive oil, onion; external, on } \\
\text { abdomen }\end{array}$ & $\begin{array}{l}\text { Yeşilada, et } \\
\text { al. } 1993\end{array}$ & Mediterranean \\
\hline $\begin{array}{l}\text { Pinus nigra J. F. Arnold } \\
\text { ssp. pallasiana (Lamb.) } \\
\text { Holmboe } \\
\text { (Pinaceae) }\end{array}$ & Çam kabuğu & 12 & $\mathrm{Bk}$ & $\begin{array}{l}\text { For diarrhea, ground on stone } \\
\text { mortar, mixed with yogurt, } \\
\text { eaten }\end{array}$ & $\begin{array}{l}\text { Yeşilada, et } \\
\text { al. } 1995\end{array}$ & $\begin{array}{l}\text { South Anatolia, } \\
\text { Taurus Mts }\end{array}$ \\
\hline
\end{tabular}




\begin{tabular}{|c|c|c|c|c|c|c|}
\hline $\begin{array}{l}\text { Pinus nigra J. F. Arnold } \\
\text { ssp. pallasiana (Lamb.) } \\
\text { Holmboe } \\
\text { (Pinaceae) }\end{array}$ & Bise & 4 & $\operatorname{Tr}$ & $\begin{array}{l}\text { For abdominal pain, diarrhea, } \\
\text { internal, one drop in glass of } \\
\text { water }\end{array}$ & $\begin{array}{l}\text { Yeşilada, et } \\
\text { al. } 1995\end{array}$ & $\begin{array}{l}\text { South Anatolia, } \\
\text { Taurus Mts }\end{array}$ \\
\hline $\begin{array}{l}\text { Pinus sp. } \\
\quad \text { (Pinaceae) }\end{array}$ & Çam Katranı & 8600274 & $\operatorname{Tr}$ & $\begin{array}{l}\text { Small pieces of onion mixed } \\
\text { with tar and olive oil for } \\
\text { diarrhea; applied to abdomen for } \\
\text { cold in stomach }\end{array}$ & $\begin{array}{l}\text { Tabata et al, } \\
1988\end{array}$ & $\begin{array}{l}\text { Konya, Akseki, } \\
\text { Çimi köy, Kuyu } \\
\text { District }\end{array}$ \\
\hline $\begin{array}{l}\text { Pinus sp. } \\
\text { (Pinaceae) }\end{array}$ & Karacaotu & 9100406 & $\operatorname{Tr}$ & $\begin{array}{l}\text { Tar applied on abdomen, or one } \\
\text { drop in glass of water, drunk } \\
\text { against abdominal pain or } \\
\text { diarrhea }\end{array}$ & $\begin{array}{l}\text { Tabata, et al } \\
1993\end{array}$ & $\begin{array}{l}\text { Konya, Hadım, } \\
\text { Dolhanlar }\end{array}$ \\
\hline $\begin{array}{l}\text { Punica granatum L. } \\
\text { (Punicaceae) }\end{array}$ & Nar & 10 & $\mathrm{Pe}$ & $\begin{array}{l}\text { For diarrhea; dried rind of the } \\
\text { fruit is ingested }\end{array}$ & $\begin{array}{l}\text { Sezik, et al. } \\
2001\end{array}$ & Central Anatolia \\
\hline $\begin{array}{l}\text { Pyracantha coccinea } \mathrm{M} . \\
\text { Roem. } \\
\quad \text { (Rosaceae) }\end{array}$ & Yemişen & 91 & $\mathrm{Lf}$ & $\begin{array}{l}\text { For diarrhea (in humans or } \\
\text { animals), decoction, internal, } 1 \\
\text { x 1, used cold }\end{array}$ & $\begin{array}{l}\text { Tuzlaci \& } \\
\text { Aymaz } \\
2001\end{array}$ & Gönen (Balıkesir) \\
\hline $\begin{array}{l}\text { Pyrus elaeagnifolia Pall. } \\
\text { (Rosaceae) }\end{array}$ & Kirahlat1 & 9 & $\mathrm{Fr}$ & For diarrhea, ingest dried fruits & $\begin{array}{l}\text { Honda, et al. } \\
1996\end{array}$ & West Anatolia \\
\hline $\begin{array}{l}\text { Pyrus elaeagnifolia Pall. } \\
\text { (Rosaceae) }\end{array}$ & Çördük & 23 & $\mathrm{Fr}$ & $\begin{array}{l}\text { For diarrhea, dried, eaten, } \\
\text { intenra }\end{array}$ & $\begin{array}{l}\text { Fujita, et al. } \\
1995\end{array}$ & $\begin{array}{l}\text { Mid \& West Black } \\
\text { Sea }\end{array}$ \\
\hline $\begin{array}{l}\text { Pyrus elaeagnifolia } \\
\text { Pallas } \\
\quad \text { (Rosaceae) }\end{array}$ & Ahlat & 10 & $\mathrm{Fr}$ & For diarrhea; stewed fruits & $\begin{array}{l}\text { Sezik, et al. } \\
2001\end{array}$ & Central Anatolia \\
\hline
\end{tabular}




\begin{tabular}{|c|c|c|c|c|c|c|}
\hline $\begin{array}{l}\text { Pyrus elaeagnifolia } \\
\text { Pallas } \\
\quad \text { (Rosaceae) }\end{array}$ & Bozahlat & 32 & $\mathrm{Fr}$ & $\begin{array}{l}\text { For diarrhea; fresh or dried } \\
\text { fruits are eaten or decoction as } \\
\text { tea }\end{array}$ & $\begin{array}{l}\text { Sezik, et al. } \\
2001\end{array}$ & Central Anatolia \\
\hline $\begin{array}{l}\text { Pyrus spinosa Forssk. } \\
\text { (Rosaceae) }\end{array}$ & Ahlat & & Fr & For diarrhea, eaten fresh & $\begin{array}{l}\text { Tuzlaci \& } \\
\text { Bulut } 2007\end{array}$ & Ezine (Çanakkale) \\
\hline $\begin{array}{l}\text { Quercus coccifera } \mathrm{L} . \\
\text { (Fagaceae) }\end{array}$ & $\begin{array}{l}\text { Bodur ağaç, Pelit, } \\
\text { Pinar }\end{array}$ & 1 & $\mathrm{Br}$ & $\begin{array}{l}\text { For diarrhea, decoction, internal, } \\
1 \times 1\end{array}$ & $\begin{array}{l}\text { Tuzlacı \& } \\
\text { Sadikoğlu } \\
2007\end{array}$ & Koçarlı (Aydın) \\
\hline $\begin{array}{l}\text { Quercus ithaburensis } \\
\text { Decne. ssp. macrolepis } \\
\text { (Kotschy) Hedge \& Yalt. } \\
\text { (Fagaceae) }\end{array}$ & Meşe pelit & 46 & $\mathrm{Sd}$ & $\begin{array}{l}\text { For diarrhea, crush and cook } \\
\text { seeds, internal }\end{array}$ & $\begin{array}{l}\text { Tuzlacı \& } \\
\text { Sadikoğlu } \\
2007\end{array}$ & Koçarlı (Aydın) \\
\hline $\begin{array}{l}\text { Quercus petraea (Matt.) } \\
\text { Liebl. ssp. iberica } \\
\text { (Steven ex M. Bieb.) } \\
\text { Krassiln. } \\
\quad \text { (Fagaceae) }\end{array}$ & Meşe & 35 & $\mathrm{Bk}$ & For diarrhea, decoction, internal & $\begin{array}{l}\text { Tuzlacı \& } \\
\text { Alparslan } \\
2007\end{array}$ & $\begin{array}{l}\text { Babaeski } \\
\text { (Kırklareli) }\end{array}$ \\
\hline $\begin{array}{l}\text { Quercus sp. } \\
\text { (Fagaceae) }\end{array}$ & Meşe & 9000084 & Gl & $\begin{array}{l}\text { Gall or mesemazisi pounded and } \\
5-10 \mathrm{~g} \text { of powder mixed with } \\
\text { albumen, orally for diarrhea }\end{array}$ & $\begin{array}{l}\text { Tabata, et al } \\
1993\end{array}$ & $\begin{array}{l}\text { Muğla, Göktepe, } \\
\text { Taşlı, Osman Kara }\end{array}$ \\
\hline $\begin{array}{l}\text { Rheum ribes } \mathrm{L} . \\
\text { (Polygonaceae) }\end{array}$ & Iskin, Ribes & $9,11,46$ & $\mathrm{Rt}$ & $\begin{array}{l}\text { For diabetes, diarrhea, } \\
\text { anthelmintic, decoction, tea }\end{array}$ & $\begin{array}{l}\text { Özgökçe \& } \\
\text { Özçelik } \\
2004\end{array}$ & East Anatolia \\
\hline
\end{tabular}




\begin{tabular}{|c|c|c|c|c|c|c|}
\hline $\begin{array}{l}\text { Rheum ribes } \mathrm{L} . \\
\text { (Polygonaceae) }\end{array}$ & & 36,44 & $\mathrm{Sd}$ & For diarrhea, decoction, internal & $\begin{array}{l}\text { Özgökçe \& } \\
\text { Özçelik } \\
2004\end{array}$ & East Anatolia \\
\hline $\begin{array}{l}\text { Rheum ribes } \mathrm{L} . \\
\text { (Polygonaceae) }\end{array}$ & Işgı̀n & 1 & $\mathrm{Rt}$ & $\begin{array}{l}\text { Ulcer, Diarrhea, Anthelmentic; } \\
\text { Decoction, internal }\end{array}$ & $\begin{array}{l}\text { Tabata, et } \\
\text { al. } 1994\end{array}$ & East Anatolia \\
\hline $\begin{array}{l}\text { Rheum ribes } \mathrm{L} . \\
\quad \text { (Polygonaceae) }\end{array}$ & Işgı̀, Revas & 5 & $\mathrm{Rt}$ & $\begin{array}{l}\text { Diarrhea in animals; Poultice, } \\
\text { internal }\end{array}$ & $\begin{array}{l}\text { Tabata, et } \\
\text { al. } 1994\end{array}$ & East Anatolia \\
\hline $\begin{array}{l}\text { Rheum ribes } \mathrm{L} . \\
\text { (Polygonaceae) }\end{array}$ & Işgın & 2 & $\begin{array}{l}\text { Rt, } \\
\text { Sd }\end{array}$ & Diarrhea; Decoction, internal & $\begin{array}{l}\text { Tabata, et } \\
\text { al. } 1994\end{array}$ & East Anatolia \\
\hline $\begin{array}{l}\text { Rhus coriaria } L . \\
\text { (Anacardiaceae) }\end{array}$ & Sumak & 1 & Fr & $\begin{array}{l}\text { For diarrhea-powdered fruits } \\
\text { sprinkled on boiled egg, } \\
\text { ingested }\end{array}$ & $\begin{array}{l}\text { Sezik, et al. } \\
2001\end{array}$ & Central Anatolia \\
\hline $\begin{array}{l}\text { Rhus coriaria } L . \\
\text { (Anacardiaceae) }\end{array}$ & Somak & & Fr & $\begin{array}{l}\text { For dysentery, diarrhea, boiled } \\
\text { with water and sat, eaten }\end{array}$ & $\begin{array}{l}\text { Honda, et al. } \\
1996\end{array}$ & West Anatolia \\
\hline $\begin{array}{l}\text { Rosa canina } \mathrm{L} . \\
\quad \text { (Rosaceae) }\end{array}$ & & 37,41 & $\begin{array}{l}\text { Tr, } \\
\mathrm{Rt}\end{array}$ & $\begin{array}{l}\text { For hemorrhoids and diarrhea; } \\
\text { decoction as tea }\end{array}$ & $\begin{array}{l}\text { Sezik, et al. } \\
2001\end{array}$ & Central Anatolia \\
\hline $\begin{array}{l}\text { Rosa canina } \mathrm{L} . \\
\quad \text { (Rosaceae) }\end{array}$ & $\begin{array}{l}\text { Sitmagülu, } \\
\text { Kuşburnu }\end{array}$ & 17 & $\mathrm{Fr}$ & $\begin{array}{l}\text { For diarrhea (malaria, } \\
\text { hemorrhoids, hepatitis, stomach } \\
\text { ache, bronchitis), decoction, } \\
\text { internal }\end{array}$ & $\begin{array}{l}\text { Tuzlacı \& } \\
\text { Aymaz } \\
2001\end{array}$ & Gönen (Balıkesir) \\
\hline $\begin{array}{l}\text { Rosa canina } \mathrm{L} . \\
\quad \text { (Rosaceae) }\end{array}$ & Kuşburnu & 11 & Fl & $\begin{array}{l}\text { For abdominal pain, diarrhea, } \\
\text { decoction }\end{array}$ & $\begin{array}{l}\text { Yeşilada, et } \\
\text { al. } 1999\end{array}$ & Northwest Anatolia \\
\hline $\begin{array}{l}\text { Rosa canina L. } x \text { R. } \\
\text { heckeliana Tratt. } \\
\text { (Rosaceae) }\end{array}$ & İtburnu & 15 & $\mathrm{Rt}$ & $\begin{array}{l}\text { For abdominal pain, diarrhea, } \\
\text { decoction }\end{array}$ & $\begin{array}{l}\text { Yeşilada, et } \\
\text { al. } 1995\end{array}$ & $\begin{array}{l}\text { South Anatolia, } \\
\text { Taurus Mts }\end{array}$ \\
\hline
\end{tabular}




\begin{tabular}{|c|c|c|c|c|c|c|}
\hline $\begin{array}{l}\text { Rosa sempervirens } \mathrm{L} . \\
\quad \text { (Rosaceae) }\end{array}$ & $\begin{array}{l}\text { Sitmagülu, } \\
\text { Kuşburnu }\end{array}$ & 17 & Fr & $\begin{array}{l}\text { For diarrhea (malaria, } \\
\text { hemorrhoids, hepatitis, stomach } \\
\text { ache, bronchitis), decoction, } \\
\text { internal }\end{array}$ & $\begin{array}{l}\text { Tuzlac1 \& } \\
\text { Aymaz } \\
2001\end{array}$ & Gönen (Balıkesir) \\
\hline $\begin{array}{l}\text { Rubus canescens DC. } \\
\text { (Rosaceae) }\end{array}$ & Karantı, Karamuk & 17 & Fr & $\begin{array}{l}\text { For diarrhea (antiemetic, } \\
\text { hemorrhoids, anaemia, } \\
\text { asthenopia, woundes), fruits } \\
\text { eaten }\end{array}$ & $\begin{array}{l}\text { Tuzlaci \& } \\
\text { Aymaz } \\
2001\end{array}$ & Gönen (Balıkesir) \\
\hline $\begin{array}{l}\text { Rubus sp. } \\
\quad \text { (Rosaceae) }\end{array}$ & Böğürtlencik & 8600294 & $\mathrm{Rt}$ & Decoction taken for diarrhea & $\begin{array}{l}\text { Tabata et al, } \\
1988\end{array}$ & $\begin{array}{l}\text { South Anatolia, } \\
\text { Taurus Mts, } \\
\text { Antalya, Elmalı, } \\
\text { Büyük Söğle }\end{array}$ \\
\hline $\begin{array}{l}\text { Rubus ulmifolius Schott } \\
\text { (Rosaceae) }\end{array}$ & Karantı, Karamuk & 17 & Fr & $\begin{array}{l}\text { For diarrhea (antiemetic, } \\
\text { hemorrhoids, anaemia, } \\
\text { asthenopia, woundes), fruits } \\
\text { eaten }\end{array}$ & $\begin{array}{l}\text { Tuzlaci \& } \\
\text { Aymaz } \\
2001\end{array}$ & Gönen (Balıkesir) \\
\hline $\begin{array}{l}\text { Rumex conglomeratus } \\
\text { Murray } \\
\quad \text { (Polygonaceae) }\end{array}$ & İlabada & 11 & $\mathrm{Sd}$ & For diarrhea, decoction, internal & $\begin{array}{l}\text { Yeşilada, et } \\
\text { al. } 1993\end{array}$ & Mediterranean \\
\hline $\begin{array}{l}\text { Rumex patienta L. } \\
\text { (Polygonaceae) }\end{array}$ & Enikmancar & $23,17,18$ & $\mathrm{Sd}$ & $\begin{array}{l}\text { To stop diarrhea, decoction of } \\
\text { seeds, leaf used Guylek, Efelek }\end{array}$ & $\begin{array}{l}\text { Simsek, et } \\
\text { al.2004 }\end{array}$ & Ankara area \\
\hline $\begin{array}{l}\text { Salvia fruticosa Mill. } \\
\text { (Lamiaceae) }\end{array}$ & $\begin{array}{l}\text { Ada çay1, } \\
\text { Moşapla }\end{array}$ & 21 & Lf & $\begin{array}{l}\text { For stomach ailment, diarrhea, } \\
\text { decoction, internal }\end{array}$ & $\begin{array}{l}\text { Tuzlacı \& } \\
\text { Bulut } 2007\end{array}$ & Ezine (Çanakkale) \\
\hline $\begin{array}{l}\text { Sorbus domestica L. } \\
\text { (Rosaceae) }\end{array}$ & Övez & 25 & Fr & $\begin{array}{l}\text { For diarrhea, } 5-10 \text { pieces of } \\
\text { fresh fruit eaten }\end{array}$ & $\begin{array}{l}\text { Simsek, et } \\
\text { al.2004 }\end{array}$ & Ankara area \\
\hline $\begin{array}{l}\text { Sorbus domestica L. } \\
\quad \text { (Rosaceae) }\end{array}$ & Hurma & & Frt & For diarrhea, internal, eaten & $\begin{array}{l}\text { Sezik, et al. } \\
1997\end{array}$ & East Anatolia \\
\hline
\end{tabular}




\begin{tabular}{|c|c|c|c|c|c|c|}
\hline $\begin{array}{l}\text { Sorbus domestica L. } \\
\quad \text { (Rosaceae) }\end{array}$ & Uvaz & 2,4 & $\mathrm{Fr}$ & $\begin{array}{l}\text { To stop diarrhea; red fruits are } \\
\text { eaten }\end{array}$ & $\begin{array}{l}\text { Yeşilada, et } \\
\text { al. } 1999\end{array}$ & Northwest Anatolia \\
\hline $\begin{array}{l}\text { Sorghum cernuum Willd. } \\
\text { (Poaceae) }\end{array}$ & Gilgil & 25 & $\mathrm{Fr}$ & $\begin{array}{l}\text { For diarrhea, roasted, millet } \\
\text { eaten }\end{array}$ & $\begin{array}{l}\text { Yeşilada, et } \\
\text { al. } 1995\end{array}$ & $\begin{array}{l}\text { South Anatolia, } \\
\text { Taurus Mts }\end{array}$ \\
\hline $\begin{array}{l}\text { Stachys sp. } \\
\quad \text { (Lamiaceae) }\end{array}$ & & 94578 & $\mathrm{Hb}$ & $\begin{array}{l}\text { Decoction used as tea against } \\
\text { colitis }\end{array}$ & $\begin{array}{l}\text { Honda, et al. } \\
1996\end{array}$ & $\begin{array}{l}\text { Konya, Halkapınar, } \\
\text { Büyük Doğan }\end{array}$ \\
\hline $\begin{array}{l}\text { Teucrium polium } \mathrm{L} . \\
\text { (Lamiaceae) }\end{array}$ & Merven & 2 & $\mathrm{Hb}$ & $\begin{array}{l}\text { For diarrhea, internal, decoction, } \\
\text { also hemorrhoids }\end{array}$ & $\begin{array}{l}\text { Sezik, et al } \\
1997\end{array}$ & East Anatolia \\
\hline $\begin{array}{l}\text { Teucrium polium } \mathrm{L} . \\
\text { (Lamiaceae) }\end{array}$ & Acı yavşan & 18 & $\mathrm{Hb}$ & $\begin{array}{l}\text { For abdominal pain, diarrhea, } \\
\text { high fever, decoction, internal }\end{array}$ & $\begin{array}{l}\text { Yeşilada, et } \\
\text { al. } 1995\end{array}$ & $\begin{array}{l}\text { South Anatolia, } \\
\text { Taurus Mts }\end{array}$ \\
\hline $\begin{array}{l}\text { Tribulus terrestris } \mathrm{L} . \\
\text { (Zygophyllaceae) }\end{array}$ & Dadaşotu & 28 & $\mathrm{Hb}$ & For diarrhea, internal, decoction & $\begin{array}{l}\text { Sezik, et al. } \\
1997\end{array}$ & East Anatolia \\
\hline $\begin{array}{l}\text { Unknown } \\
\text { (Poaceae) }\end{array}$ & $\begin{array}{l}\text { Gilgil, } \\
\text { Süpürgedarıs1 }\end{array}$ & 9000213 & $\mathrm{Sd}$ & $\begin{array}{l}\text { Seeds roasted, milled, mixed } \\
\text { with poultice of komec, Malva } \\
\text { neglecta, taken for diarrhea }\end{array}$ & $\begin{array}{l}\text { Tabata, et al } \\
1993\end{array}$ & $\begin{array}{l}\text { Maraş, Andırın, } \\
\text { Darıvası, } \\
\text { Ballarobası mah, } \\
\text { Dede bal }\end{array}$ \\
\hline $\begin{array}{l}\text { Urtica dioica L., } U . \\
\text { urens } \mathrm{L} . \\
\quad \text { (Urticaceae) }\end{array}$ & Gezerek, Yığınç & 8 & Lf & Diarrhea; Tea, internal & $\begin{array}{l}\text { Tabata, et } \\
\text { al. } 1994\end{array}$ & East Anatolia \\
\hline
\end{tabular}




\begin{tabular}{|c|c|c|c|c|c|c|}
\hline $\begin{array}{l}\text { Urtica sp. } \\
\text { (Urticaceae) }\end{array}$ & Gezerek yığınç & 8600147 & Lf & Decoction for diarrhea & $\begin{array}{l}\text { Tabata et al, } \\
1988\end{array}$ & $\begin{array}{l}\text { Northwest Anatolia, } \\
\text { Bitlis, Sibek, } \\
\text { Aridağ, Yanıkçay }\end{array}$ \\
\hline $\begin{array}{l}\text { Urtica urens L. } \\
\text { (Urticaceae) }\end{array}$ & Isırgan otu & all & $\mathrm{Lf}$ & For diarrhea, tea, internal & $\begin{array}{l}\text { Özgökçe \& } \\
\text { Özçelik } \\
2004\end{array}$ & East Anatolia \\
\hline $\begin{array}{l}\text { Verbascum sp. } \\
\text { (Scrophulariaceae) }\end{array}$ & Mosi jehri & 8600065 & Rt & $\begin{array}{l}\text { Root boiled, cooled, } 1 \text { Tbs taken } \\
\text { every AM 1-2 days for diarrhea }\end{array}$ & $\begin{array}{l}\text { Tabata et al, } \\
1988\end{array}$ & $\begin{array}{l}\text { East Anatolia, Van, } \\
\text { Gevaş }\end{array}$ \\
\hline $\begin{array}{l}\text { Vicia ervilia (L.) Willd. } \\
\text { (Fabaceae) }\end{array}$ & Burçak & 9 & $\mathrm{Sd}$ & $\begin{array}{l}\text { For diarrhea, pounded with } \\
\text { honeycomb and eggs, pills }\end{array}$ & $\begin{array}{l}\text { Honda, et al. } \\
1996\end{array}$ & West Anatolia \\
\hline $\begin{array}{l}\text { Viscum album L. var. } \\
\text { album } \\
\quad \text { (Santalaceae) }\end{array}$ & Güveltek otu & 10 & $\mathrm{Hb}$ & $\begin{array}{l}\text { For diarrhea; plant collected } \\
\text { from pear tree is dried and } \\
\text { pounded with honey and } \\
\text { ingested }\end{array}$ & $\begin{array}{l}\text { Sezik, et al. } \\
2001\end{array}$ & Central Anatolia \\
\hline $\begin{array}{l}\text { Vitex agnus-castus } \mathrm{L} . \\
\text { (Lamiaceae) }\end{array}$ & Ayit & 29 & $\begin{array}{l}\text { Fr, } \\
\text { Lf }\end{array}$ & $\begin{array}{l}\text { For diarrhea, internal, Leaves } \\
\text { for nausea, headache }\end{array}$ & $\begin{array}{l}\text { Tuzlaci \& } \\
\text { Bulut } 2007\end{array}$ & Ezine (Çanakkale) \\
\hline
\end{tabular}

$\mathrm{Ae}=$ Aerial parts, $\mathrm{All}=$ Whole plant, $\mathrm{Bk}=\mathrm{Bark}, \mathrm{Bn}=\mathrm{Bean}, \mathrm{Br}=\mathrm{Branches}, \mathrm{Fl}=\mathrm{Flowers}, \mathrm{Fr}=\mathrm{Fruits}, \mathrm{Hb}=\mathrm{Herb}, \mathrm{Lf}=\mathrm{Leaves}, \mathrm{Pe}=\mathrm{Pericarp}, \mathrm{Rt}=\mathrm{Root}$, $\mathrm{Sd}=$ Seed, $\mathrm{Tr}=\mathrm{Tar}$ 
Appendix 4. Antibacterial Activity of Extracts (1-34) and Controls

(MICs in $\mu \mathrm{g} / \mathrm{ml}$, minimum bactericidal/-static (MBC)/(MBS) concentrations in $\mu \mathrm{g} / \mathrm{ml}$, and plated CFU's)

\begin{tabular}{|c|c|c|c|c|c|c|}
\hline \multirow[b]{3}{*}{ Extracts } & \multicolumn{6}{|c|}{ Gram negative } \\
\hline & \multicolumn{3}{|c|}{$\begin{array}{l}\text { Escherichia coli } \\
\text { ATCC } 35218\end{array}$} & \multicolumn{3}{|c|}{$\begin{array}{c}\text { Pseudomonas aeruginosa } \\
\text { ATCC } 10145\end{array}$} \\
\hline & MIC & MBC/MBS & CFU/mL & MIC & $\mathrm{MBC} / \mathrm{MBS}$ & $\mathrm{CFU} / \mathrm{mL}$ \\
\hline 1. $\mathrm{AC} \mathrm{MeOH}$ & 128 & $512 / 128$ & $1.1 \times 10^{5}$ & 64 & $-/ \geq 128$ & $1.8 \times 10^{5}$ \\
\hline 2. $\mathrm{AC} \mathrm{H}_{2} \mathrm{O}$ & 128 & $512 / \geq 128$ & $1.2 \times 10^{5}$ & 64 & $-/ \geq 128$ & $6.5 \times 10^{4}$ \\
\hline 3. $\mathrm{AM} \mathrm{MeOH}$ & 128 & $512 / 128$ & $7.8 \times 10^{4}$ & 64 & $-/ \geq 128$ & $3.1 \times 10^{4}$ \\
\hline 4. $\mathrm{AM} \mathrm{H}_{2} \mathrm{O}$ & 128 & $-/ \geq 128$ & TNC & 64 & $-/ \geq 128$ & $1.1 \times 10^{5}$ \\
\hline 5. $\mathrm{CO} \mathrm{MeOH}$ & 128 & $512 / 128$ & $1.8 \times 10^{5}$ & 64 & $-/ \geq 128$ & $4.9 \times 10^{4}$ \\
\hline 6. $\mathrm{CO} \mathrm{H}_{2} \mathrm{O}$ & 128 & $512 / \geq 128$ & $9.2 \times 10^{4}$ & 64 & $-/ \geq 128$ & $4.5 \times 10^{4}$ \\
\hline 7. $\mathrm{HP} \mathrm{MeOH}$ & 128 & $512 / 128$ & $1.7 \times 10^{5}$ & 64 & $-/ \geq 128$ & $4.0 \times 10^{4}$ \\
\hline 8. $\mathrm{HP} \mathrm{H}_{2} \mathrm{O}$ & 128 & $512 / \geq 128$ & $7.0 \times 10^{4}$ & 64 & $-/ \geq 128$ & $3.0 \times 10^{5}$ \\
\hline 9. $\mathrm{ML} \mathrm{MeOH}$ & 128 & $512 / 128$ & $2.7 \times 10^{5}$ & 64 & $-/ \geq 128$ & $4.7 \times 10^{4}$ \\
\hline 10. $\mathrm{ML} \mathrm{H}_{2} \mathrm{O}$ & 128 & $512 / \geq 128$ & $1.9 \times 10^{5}$ & 128 & $-/ \geq 128$ & $7.4 \times 10^{4}$ \\
\hline 11. $\mathrm{PR} \mathrm{MeOH}$ & 128 & $512 / 128$ & $8.2 \times 10^{5}$ & 128 & $-/ \geq 128$ & $6.2 \times 10^{4}$ \\
\hline 12. $\mathrm{PR} \mathrm{H}_{2} \mathrm{O}$ & 128 & $512 / \geq 128$ & $7.2 \times 10^{4}$ & 128 & $-/ \geq 128$ & $5.4 \times 10^{4}$ \\
\hline 13. $\mathrm{RhC} \mathrm{MeOH}$ & 128 & $-/ 128$ & TNC & 128 & $-/ \geq 128$ & $3.0 \times 10^{4}$ \\
\hline 14. $\mathrm{RhC} \mathrm{H}_{2} \mathrm{O}$ & 128 & $-/ \geq 128$ & TNC & 128 & $-/ \geq 128$ & $4.9 \times 10^{4}$ \\
\hline 15. RoC MeOH & 128 & $-/ 128$ & TNC & 128 & $-/ \geq 128$ & $2.6 \times 10^{4}$ \\
\hline 16. RoC $\mathrm{H}_{2} \mathrm{O}$ & 128 & $-/ \geq 128$ & TNC & 128 & $-/ \geq 128$ & $5.5 \times 10^{4}$ \\
\hline 17. RoCG MeOH & 64 & $-1 \geq 64$ & TNC & 64 & $128 / 64$ & $1.5 \times 10^{4}$ \\
\hline 18. RoCG $\mathrm{H}_{2} \mathrm{O}$ & 128 & $512 / 128$ & $8.0 \times 10^{4}$ & 128 & $-/ 128$ & $2.0 \times 10^{4}$ \\
\hline 19. RPF MeOH & 128 & $512 / \geq 128$ & $9.5 \times 10^{4}$ & 128 & $-/ 128$ & $9.0 \times 10^{4}$ \\
\hline 20. $\mathrm{RPF} \mathrm{H}_{2} \mathrm{O}$ & 128 & $512 / 128$ & $6.0 \times 10^{4}$ & 128 & $-/ \geq 128$ & TNC \\
\hline 21. RPL MeOH & 128 & $512 / \geq 128$ & $1.0 \times 10^{4}$ & 128 & $-/ \geq 128$ & TNC \\
\hline 22. $\mathrm{RPL} \mathrm{H}_{2} \mathrm{O}$ & 128 & $512 / 128$ & $5.4 \times 10^{4}$ & 128 & $-/ \geq 128$ & $6.4 \times 10^{4}$ \\
\hline 23. TF MeOH & 128 & $-/ \geq 128$ & TNC & 64 & $-/ \geq 64$ & TNC \\
\hline 24. $\mathrm{TF} \mathrm{H}_{2} \mathrm{O}$ & 128 & $512 / 128$ & $1.9 \times 10^{4}$ & 128 & $-/ \geq 128$ & TNC \\
\hline 25. TP MeOH & 128 & $512 / \geq 128$ & $9.2 \times 10^{4}$ & 64 & $\geq 128 /-$ & - \\
\hline 26. TP $\mathrm{H}_{2} \mathrm{O}$ & 128 & $512 / 128$ & $1.7 \times 10^{5}$ & 64 & $\geq 128 /-$ & - \\
\hline 27. TT MeOH & 128 & $-/ \geq 128$ & TNC & 64 & $\geq 256 / \geq 64$ & - \\
\hline 28. TT $\mathrm{H}_{2} \mathrm{O}$ & 128 & $-/ 128$ & TNC & 64 & $256 / \geq 64$ & - \\
\hline 29. UD MeOH & 128 & $-/ \geq 128$ & TNC & 64 & $\geq 128 /-$ & - \\
\hline 30. UD $\mathrm{H}_{2} \mathrm{O}$ & 128 & $-/ 128$ & TNC & 64 & $256 / \geq 64$ & - \\
\hline 31. VAA MeO & 128 & $512 / \geq 128$ & $2.5 \times 10^{5}$ & 64 & $256 / \geq 64$ & - \\
\hline 32. VAA $\mathrm{H}_{2} \mathrm{O}$ & 128 & $512 / 128$ & $6.0 \times 10^{4}$ & 64 & $\geq 128 / 64$ & - \\
\hline 33. VAC MeOH & 64 & $\geq 128 / \geq 64$ & $2.3 \times 10^{4}$ & 64 & $256 / \geq 64$ & - \\
\hline 34. VAC $\mathrm{H}_{2} \mathrm{O}$ & 64 & $-/ \geq 64$ & TNC & 64 & $\geq 128 / 64$ & - \\
\hline Ciprofloxacin & 0.12 & & & 1 & & \\
\hline Gentamicin & - & & & 0.5 & & \\
\hline TMP-SMX & 2 & & & - & & \\
\hline Nitrofurantoin & - & & & - & & \\
\hline Azithromicin & - & & & - & & \\
\hline
\end{tabular}

$\mathrm{MeOH}$ : methanolic extract; $\mathrm{H}_{2} \mathrm{O}$ : water extract 
Appendix 4. Antibacterial Activity of Extracts (1-34) and Controls

\begin{tabular}{|c|c|c|c|c|c|c|}
\hline \multirow[b]{3}{*}{ Extracts } & \multicolumn{6}{|c|}{ Gram negative } \\
\hline & \multicolumn{3}{|c|}{$\begin{array}{c}\text { Klebsiella pneumoniae } \\
\text { RSKK } 574\end{array}$} & \multicolumn{3}{|c|}{$\begin{array}{c}\text { Salmonella enteriditis } \\
\text { RSKK } 538\end{array}$} \\
\hline & MIC & MBC/MBS & $\mathrm{CFU} / \mathrm{mL}$ & MIC & MBC/MBS & $\mathrm{CFU} / \mathrm{mL}$ \\
\hline 1. $\mathrm{AC} \mathrm{MeOH}$ & 64 & $\geq 128 / 64$ & $4.6 \times 10^{3}$ & 128 & $\geq 256 / 128$ & $7.4 \times 10^{3}$ \\
\hline 2. $\mathrm{AC} \mathrm{H}_{2} \mathrm{O}$ & 64 & $\geq 128 / 64$ & $7.6 \times 10^{3}$ & 128 & $\geq 256 / 128$ & $8.1 \times 10^{3}$ \\
\hline 3. $\mathrm{AM} \mathrm{MeOH}$ & 64 & $\geq 128 / 64$ & $6.5 \times 10^{3}$ & 128 & $\geq 256 / 128$ & $6.4 \times 10^{3}$ \\
\hline 4. $\mathrm{AM} \mathrm{H}_{2} \mathrm{O}$ & 64 & $\geq 128 / 64$ & $5.9 \times 10^{3}$ & 128 & $\geq 256 / 128$ & $6.0 \times 10^{3}$ \\
\hline 5. $\mathrm{CO} \mathrm{MeOH}$ & 64 & $\geq 128 / 64$ & $1.1 \times 10^{3}$ & 128 & $\geq 256 / 128$ & $9.0 \times 10^{2}$ \\
\hline 6. $\mathrm{CO} \mathrm{H}_{2} \mathrm{O}$ & 64 & $\geq 128 / 64$ & $8.5 \times 10^{3}$ & 128 & $\geq 256 / 128$ & $3.7 \times 10^{3}$ \\
\hline 7. $\mathrm{HP} \mathrm{MeOH}$ & 64 & $\geq 128 / 64$ & $8.2 \times 10^{3}$ & 128 & $\geq 256 / 128$ & $3.4 \times 10^{3}$ \\
\hline 8. $\mathrm{HP} \mathrm{H}_{2} \mathrm{O}$ & 64 & $\geq 128 / 64$ & $8.3 \times 10^{3}$ & 128 & $\geq 256 / 128$ & $9.1 \times 10^{3}$ \\
\hline 9. $\mathrm{ML} \mathrm{MeOH}$ & 128 & $\geq 128 / 64$ & $3.7 \times 10^{3}$ & 128 & $\geq 256 / 128$ & $1.2 \times 10^{4}$ \\
\hline 10. $\mathrm{ML} \mathrm{H}_{2} \mathrm{O}$ & 128 & $\geq 256 / 128$ & $3.9 \times 10^{3}$ & 128 & $\geq 256 / 128$ & $5.4 \times 10^{3}$ \\
\hline 11. $\mathrm{PR} \mathrm{MeOH}$ & 128 & $\geq 256 / 128$ & $2.8 \times 10^{3}$ & 128 & $\geq 256 / 128$ & $5.1 \times 10^{3}$ \\
\hline 12. $\mathrm{PR} \mathrm{H}_{2} \mathrm{O}$ & 128 & $\geq 256 / 128$ & $2.0 \times 10^{3}$ & 128 & $\geq 256 / 128$ & $2.4 \times 10^{3}$ \\
\hline 13. $\mathrm{RhC} \mathrm{MeOH}$ & 128 & $\geq 256 / 128$ & $4.2 \times 10^{3}$ & 128 & $\geq 256 / 128$ & $4.6 \times 10^{3}$ \\
\hline 14. $\mathrm{RhC} \mathrm{H}_{2} \mathrm{O}$ & 128 & $\geq 256 / 128$ & $1.0 \times 10^{4}$ & 128 & $\geq 256 / 128$ & $6.8 \times 10^{3}$ \\
\hline 15. $\mathrm{RoCMeOH}$ & 128 & $\geq 256 / 128$ & $3.2 \times 10^{3}$ & 128 & $\geq 256 / 128$ & $8.8 \times 10^{3}$ \\
\hline 16. $\mathrm{RoC} \mathrm{H}_{2} \mathrm{O}$ & 128 & $\geq 256 / 128$ & $2.9 \times 10^{3}$ & 128 & $\geq 256 / 128$ & $6.1 \times 10^{3}$ \\
\hline 17. RoCG MeOH & 128 & $\geq 256 / 128$ & $9.4 \times 10^{3}$ & 64 & $\geq 256 / 128$ & $3.2 \times 10^{4}$ \\
\hline 18. RoCG $\mathrm{H}_{2} \mathrm{O}$ & 128 & $\geq 256 / 128$ & $4.6 \times 10^{3}$ & 128 & $\geq 256 / 128$ & $1.5 \times 10^{4}$ \\
\hline 19. RPF MeOH & 128 & $\geq 256 / 128$ & $8.0 \times 10^{3}$ & 128 & $\geq 256 / 128$ & $7.8 \times 10^{3}$ \\
\hline 20. $\mathrm{RPF} \mathrm{H}_{2} \mathrm{O}$ & 128 & $\geq 256 / 128$ & $3.3 \times 10^{3}$ & 128 & $\geq 256 / 128$ & $1.6 \times 10^{4}$ \\
\hline 21. RPL MeOH & 128 & $\geq 256 / 128$ & $5.0 \times 10^{3}$ & 128 & $\geq 256 / 128$ & $1.4 \times 10^{4}$ \\
\hline 22. $\mathrm{RPL} \mathrm{H}_{2} \mathrm{O}$ & 128 & $\geq 256 / 128$ & $5.4 \times 10^{3}$ & 128 & $\geq 256 / 128$ & $1.1 \times 10^{4}$ \\
\hline 23. TF MeOH & 128 & $\geq 256 / 128$ & $3.9 \times 10^{3}$ & 128 & $\geq 256 / 128$ & $1.1 \times 10^{4}$ \\
\hline 24. $\mathrm{TF} \mathrm{H}_{2} \mathrm{O}$ & 128 & $\geq 256 / 128$ & $7.8 \times 10^{3}$ & 128 & $\geq 256 / 128$ & $6.7 \times 10^{3}$ \\
\hline 25. TP MeOH & 128 & $\geq 128 /-$ & - & 128 & $\geq 256 / 128$ & $2.7 \times 10^{4}$ \\
\hline 26. TP $\mathrm{H}_{2} \mathrm{O}$ & 128 & $\geq 128 /-$ & - & 128 & $\geq 256 / 128$ & $9.1 \times 10^{3}$ \\
\hline 27. TT MeOH & 128 & $512 / 128$ & $7.1 \times 10^{3}$ & 128 & $\geq 256 / 128$ & $2.7 \times 10^{4}$ \\
\hline 28. TT $\mathrm{H}_{2} \mathrm{O}$ & 128 & $512 / 128$ & $1.0 \times 10^{4}$ & 128 & $\geq 256 / 128$ & $2.4 \times 10^{4}$ \\
\hline 29. UD MeOH & 128 & $\geq 128 /-$ & - & 128 & $\geq 256 / 128$ & $1.5 \times 10^{4}$ \\
\hline 30. UD $\mathrm{H}_{2} \mathrm{O}$ & 128 & $\geq 256 / 128$ & $6.6 \times 10^{3}$ & 128 & $\geq 256 / 128$ & $1.4 \times 10^{4}$ \\
\hline 31. VAA MeO & 128 & $\geq 256 / 128$ & $3.7 \times 10^{3}$ & 128 & $\geq 256 / 128$ & $2.0 \times 10^{4}$ \\
\hline 32. VAA $\mathrm{H}_{2} \mathrm{O}$ & 128 & $128 /-$ & $1.1 \times 10^{4}$ & 128 & $\geq 256 / 128$ & $1.3 \times 10^{4}$ \\
\hline 33. VAC $\mathrm{MeOH}$ & 128 & $128 /-$ & $7.5 \times 10^{3}$ & 128 & $\geq 256 / 128$ & $1.3 \times 10^{4}$ \\
\hline 34. VAC $\mathrm{H}_{2} \mathrm{O}$ & 128 & $128 /-$ & $8.5 \times 10^{3}$ & 128 & $\geq 256 / 128$ & $5.8 \times 10^{3}$ \\
\hline Ciprofloxacin & 0.5 & & & 0.5 & & \\
\hline Gentamicin & - & & & - & & \\
\hline TMP-SMX & 1 & & & 1 & & \\
\hline Nitrofurantoin & - & & & 0.25 & & \\
\hline Azithromycin & - & & & 0.5 & & \\
\hline
\end{tabular}

$\mathrm{MeOH}$ : methanolic extract; $\mathrm{H}_{2} \mathrm{O}$ : water extract 
Appendix 4. Antibacterial Activity of Extracts (1-34) and Controls

\begin{tabular}{|c|c|c|c|c|c|c|}
\hline \multirow[b]{3}{*}{ Extracts } & \multicolumn{6}{|c|}{ Gram negative } \\
\hline & \multicolumn{3}{|c|}{$\begin{array}{c}\text { Shigella dysenteriae } \\
\text { RSKK } 851\end{array}$} & \multicolumn{3}{|c|}{$\begin{array}{c}\text { Vibrio cholerae ojawa } \\
\text { RSKK } 96023\end{array}$} \\
\hline & MIC & MBC/MBS & $\mathrm{CFU} / \mathrm{mL}$ & MIC & MBC/MBS & $\mathrm{CFU} / \mathrm{mL}$ \\
\hline 1. $\mathrm{AC} \mathrm{MeOH}$ & 64 & $256 / 128$ & $6.4 \times 10^{3}$ & 64 & $128 / \geq 64$ & $2.3 \times 10^{4}$ \\
\hline 2. $\mathrm{AC} \mathrm{H}_{2} \mathrm{O}$ & 128 & $256 / 128$ & $9.9 \times 10^{3}$ & 64 & $128 / \geq 64$ & $2.3 \times 10^{4}$ \\
\hline 3. $\mathrm{AM} \mathrm{MeOH}$ & 128 & $256 / 128$ & $2.1 \times 10^{4}$ & 64 & $128 / \geq 64$ & $2.9 \times 10^{4}$ \\
\hline 4. $\mathrm{AM} \mathrm{H}_{2} \mathrm{O}$ & 128 & $256 / 128$ & $1.4 \times 10^{4}$ & 64 & $128 / \geq 64$ & $2.5 \times 10^{4}$ \\
\hline 5. $\mathrm{CO} \mathrm{MeOH}$ & 128 & $256 / 128$ & $6.7 \times 10^{3}$ & 64 & $128 / \geq 64$ & $2.4 \times 10^{4}$ \\
\hline 6. $\mathrm{CO} \mathrm{H}_{2} \mathrm{O}$ & 128 & $256 / 128$ & $9.4 \times 10^{3}$ & 64 & $128 / \geq 64$ & $3.1 \times 10^{4}$ \\
\hline 7. $\mathrm{HP} \mathrm{MeOH}$ & 128 & $256 / 128$ & $2.1 \times 10^{4}$ & 64 & $128 / \geq 64$ & $8.2 \times 10^{3}$ \\
\hline 8. $\mathrm{HP} \mathrm{H}_{2} \mathrm{O}$ & 128 & $256 / 128$ & $1.7 \times 10^{4}$ & 64 & $128 / \geq 64$ & $2.1 \times 10^{4}$ \\
\hline 9. $\mathrm{ML} \mathrm{MeOH}$ & 128 & $256 / 128$ & $1.9 \times 10^{4}$ & 64 & $512 / \geq 64$ & $2.2 \times 10^{4}$ \\
\hline 10. $\mathrm{ML} \mathrm{H}_{2} \mathrm{O}$ & 128 & $256 / 128$ & $2.0 \times 10^{4}$ & 64 & $512 / \geq 64$ & $1.0 \times 10^{4}$ \\
\hline 11. $\mathrm{PR} \mathrm{MeOH}$ & 128 & $256 / 128$ & $1.2 \times 10^{4}$ & 64 & $512 / \geq 64$ & $2.2 \times 10^{4}$ \\
\hline 12. $\mathrm{PR} \mathrm{H}_{2} \mathrm{O}$ & 128 & $256 / 128$ & $2.4 \times 10^{4}$ & 64 & $512 / \geq 64$ & $1.4 \times 10^{4}$ \\
\hline 13. $\mathrm{RhC} \mathrm{MeOH}$ & 128 & $256 / 128$ & $2.6 \times 10^{4}$ & 64 & $512 / \geq 64$ & $1.2 \times 10^{4}$ \\
\hline 14. $\mathrm{RhC} \mathrm{H}_{2} \mathrm{O}$ & 128 & $256 / 128$ & $2.5 \times 10^{4}$ & 64 & $512 / \geq 64$ & $9.8 \times 10^{3}$ \\
\hline 15. $\mathrm{RoC} \mathrm{MeOH}$ & 128 & $256 / 128$ & $2.8 \times 10^{4}$ & 64 & $512 / \geq 64$ & $1.1 \times 10^{4}$ \\
\hline 16. $\mathrm{RoC} \mathrm{H}_{2} \mathrm{O}$ & 128 & $256 / 128$ & $1.9 \times 10^{4}$ & 64 & $512 / \geq 64$ & $1.2 \times 10^{4}$ \\
\hline 17. RoCG MeOH & 128 & $256 / 128$ & $1.4 \times 10^{4}$ & 16 & $\geq 128 / \geq 16$ & $9.0 \times 10^{3}$ \\
\hline 18. RoCG $\mathrm{H}_{2} \mathrm{O}$ & 128 & $256 / 128$ & - & 64 & $\geq 64 /-$ & - \\
\hline 19. RPF MeOH & 128 & $256 / 128$ & - & 64 & $\geq 64 /-$ & - \\
\hline 20. $\mathrm{RPF} \mathrm{H}_{2} \mathrm{O}$ & 128 & $256 / 128$ & $1.3 \times 10^{4}$ & 64 & $\geq 64 /-$ & - \\
\hline 21. RPL MeOH & 128 & $256 / 128$ & $7.3 \times 10^{3}$ & 128 & $512 / 128$ & $1.8 \times 10^{4}$ \\
\hline 22. $\mathrm{RPL} \mathrm{H}_{2} \mathrm{O}$ & 128 & $256 / 128$ & $2.1 \times 10^{4}$ & 128 & $512 / 128$ & $1.7 \times 10^{4}$ \\
\hline 23. $\mathrm{TF} \mathrm{MeOH}$ & 128 & $256 / 128$ & $2.4 \times 10^{4}$ & 128 & $512 / 128$ & TNC \\
\hline 24. $\mathrm{TF} \mathrm{H}_{2} \mathrm{O}$ & 128 & $256 / 128$ & TNC & 128 & $512 / 128$ & $1.5 \times 10^{4}$ \\
\hline 25. TP MeOH & 128 & $256 / 128$ & $3.5 \times 10^{4}$ & 128 & $512 / 128$ & $2.7 \times 10^{4}$ \\
\hline 26. TP $\mathrm{H}_{2} \mathrm{O}$ & 128 & $256 / 128$ & $3.6 \times 10^{4}$ & 128 & $512 / 128$ & $2.1 \times 10^{4}$ \\
\hline 27. TT MeOH & 128 & $256 / 128$ & $2.7 \times 10^{4}$ & 128 & $512 / 128$ & $1.1 \times 10^{4}$ \\
\hline 28. TT $\mathrm{H}_{2} \mathrm{O}$ & 128 & $256 / 128$ & $3.8 \times 10^{4}$ & 128 & $512 / 128$ & $2.1 \times 10^{4}$ \\
\hline 29. UD MeOH & 128 & $256 / 128$ & $3.3 \times 10^{4}$ & 128 & $512 / 128$ & $1.3 \times 10^{4}$ \\
\hline 30. UD $\mathrm{H}_{2} \mathrm{O}$ & 128 & $256 / 128$ & $3.0 \times 10^{4}$ & 128 & $512 / 128$ & $8.5 \times 10^{3}$ \\
\hline 31. VAA MeO & 128 & $256 / 128$ & $2.9 \times 10^{4}$ & 128 & $512 / 128$ & $2.1 \times 10^{4}$ \\
\hline 32. VAA $\mathrm{H}_{2} \mathrm{O}$ & 128 & $256 / 128$ & $3.7 \times 10^{4}$ & 128 & $512 / 128$ & $2.1 \times 10^{4}$ \\
\hline 33. VAC MeOH & 128 & $256 / 128$ & $1.7 \times 10^{4}$ & 128 & $512 / 128$ & $1.1 \times 10^{4}$ \\
\hline 34. VAC $\mathrm{H}_{2} \mathrm{O}$ & 128 & $256 / 128$ & $2.1 \times 10^{4}$ & 128 & $512 / 128$ & $1.7 \times 10^{4}$ \\
\hline Ciprofloxacin & - & & & - & & \\
\hline Gentamicin & - & & & - & & \\
\hline TMP-SMX & 1 & & & 1 & & \\
\hline Nitrofurantoin & 0.5 & & & 0.25 & & \\
\hline Azithromycin & 0.5 & & & 1 & & \\
\hline
\end{tabular}

MeOH: methanolic extract; $\mathrm{H}_{2} \mathrm{O}$ : water extract 
Appendix 4. Antibacterial Activity of Extracts (1-34) and Controls

\begin{tabular}{|c|c|c|c|c|c|c|}
\hline \multirow[b]{3}{*}{ Extracts } & \multicolumn{6}{|c|}{ Gram positive } \\
\hline & \multicolumn{3}{|c|}{$\begin{array}{c}\text { Staphylococcus aureus } \\
\text { ATCC } 25923\end{array}$} & \multicolumn{3}{|c|}{$\begin{array}{c}\text { Enterococcus faecalis } \\
\text { ATCC } 29212\end{array}$} \\
\hline & MIC & MBC/MBS & $\mathrm{CFU} / \mathrm{mL}$ & MIC & $\mathrm{MBC} / \mathrm{MBS}$ & $\mathrm{CFU} / \mathrm{mL}$ \\
\hline 1. $\mathrm{AC} \mathrm{MeOH}$ & 32 & $512 / \geq 32$ & $2.4 \times 10^{4}$ & 64 & $128 / 64$ & $3.6 \times 10^{4}$ \\
\hline 2. $\mathrm{AC} \mathrm{H}_{2} \mathrm{O}$ & 64 & $512 / \geq 64$ & $2.7 \times 10^{4}$ & 64 & $128 / 64$ & $4.1 \times 10^{4}$ \\
\hline 3. $\mathrm{AM} \mathrm{MeOH}$ & 64 & $512 / \geq 64$ & $3.3 \times 10^{4}$ & 64 & $128 / 64$ & $4.4 \times 10^{4}$ \\
\hline 4. $\mathrm{AM} \mathrm{H}_{2} \mathrm{O}$ & 128 & $512 / \geq 128$ & $2.1 \times 10^{4}$ & 64 & $128 / 64$ & $7.8 \times 10^{4}$ \\
\hline 5. $\mathrm{CO} \mathrm{MeOH}$ & 4 & $512 / \geq 4$ & $1.6 \times 10^{4}$ & 64 & $128 / 64$ & $4.1 \times 10^{4}$ \\
\hline 6. $\mathrm{CO} \mathrm{H}_{2} \mathrm{O}$ & 8 & $512 / \geq 8$ & $3.5 \times 10^{4}$ & 128 & $512 / 128$ & $8.8 \times 10^{3}$ \\
\hline 7. $\mathrm{HP} \mathrm{MeOH}$ & 16 & $512 / \geq 16$ & $2.7 \times 10^{4}$ & 128 & $512 / 128$ & $3.8 \times 10^{3}$ \\
\hline 8. $\mathrm{HP} \mathrm{H}_{2} \mathrm{O}$ & 8 & $512 / \geq 8$ & $3.7 \times 10^{4}$ & 128 & $512 / 128$ & $1.8 \times 10^{4}$ \\
\hline 9. $\mathrm{ML} \mathrm{MeOH}$ & 128 & $512 / \geq 128$ & $2.0 \times 10^{4}$ & 128 & $512 / 128$ & $4.5 \times 10^{4}$ \\
\hline 10. $\mathrm{ML} \mathrm{H} \mathrm{H}_{2} \mathrm{O}$ & 128 & $512 / \geq 128$ & $1.4 \times 10^{4}$ & 128 & $512 / 128$ & $5.4 \times 10^{4}$ \\
\hline 11. PR MeOH & 128 & $-/ \geq 128$ & $8.0 \times 10^{3}$ & 128 & $512 / 128$ & $2.8 \times 10^{4}$ \\
\hline 12. $\mathrm{PR} \mathrm{H}_{2} \mathrm{O}$ & 128 & $-/ \geq 128$ & $1.5 \times 10^{4}$ & 128 & $512 / 128$ & $7.0 \times 10^{4}$ \\
\hline 13. $\mathrm{RhC} \mathrm{MeOH}$ & 8 & $-/ \geq 8$ & $1.1 \times 10^{4}$ & 128 & $512 / 128$ & $5.7 \times 10^{4}$ \\
\hline 14. $\mathrm{RhC} \mathrm{H}_{2} \mathrm{O}$ & 32 & $-/ \geq 32$ & $8.5 \times 10^{4}$ & 128 & $512 / 128$ & $4.9 \times 10^{4}$ \\
\hline 15. $\mathrm{RoC} \mathrm{MeOH}$ & 32 & $-/ \geq 32$ & $8.6 \times 10^{4}$ & 128 & $512 / 128$ & $4.7 \times 10^{4}$ \\
\hline 16. $\mathrm{RoC} \mathrm{H}_{2} \mathrm{O}$ & 32 & $-/ \geq 32$ & $3.4 \times 10^{4}$ & 128 & $512 / 128$ & $5.0 \times 10^{4}$ \\
\hline 17. RoCG MeOH & 16 & $-/ \geq 16$ & $2.4 \times 10^{4}$ & 64 & $512 / \geq 64$ & $3.42 \times 10^{4}$ \\
\hline 18. RoCG $\mathrm{H}_{2} \mathrm{O}$ & 4 & $-/ \geq 4$ & $3.9 \times 10^{4}$ & 64 & $512 / \geq 64$ & $3.8 \times 10^{4}$ \\
\hline 19. RPF MeOH & 8 & $-/ \geq 8$ & $2.4 \times 10^{4}$ & 64 & $512 / \geq 64$ & $4.6 \times 10^{4}$ \\
\hline 20. RPF $\mathrm{H}_{2} \mathrm{O}$ & 32 & $-/ \geq 32$ & $3.1 \times 10^{4}$ & 64 & $512 / \geq 64$ & $1.2 \times 10^{4}$ \\
\hline 21. RPL MeOH & 128 & $-/ \geq 128$ & $1.7 \times 10^{4}$ & 64 & $512 / \geq 64$ & $3.0 \times 10^{4}$ \\
\hline 22. $\mathrm{RPL} \mathrm{H}_{2} \mathrm{O}$ & 128 & $-/ \geq 128$ & $1.8 \times 10^{4}$ & 64 & $512 / \geq 64$ & $3.4 \times 10^{4}$ \\
\hline 23. TF MeOH & 128 & $-/ \geq 128$ & $1.7 \times 10^{4}$ & 64 & $512 / \geq 64$ & $3.9 \times 10^{4}$ \\
\hline 24. $\mathrm{TF} \mathrm{H}_{2} \mathrm{O}$ & 128 & $-/ \geq 128$ & $2.2 \times 10^{4}$ & 64 & $512 / \geq 64$ & $4.0 \times 10^{4}$ \\
\hline 25. TP MeOH & 128 & $-/ \geq 128$ & $1.5 \times 10^{4}$ & 32 & $256 / \geq 32$ & $3.6 \times 10^{4}$ \\
\hline 26. $\mathrm{TP} \mathrm{H}_{2} \mathrm{O}$ & 128 & $-/ \geq 128$ & $1.4 \times 10^{4}$ & 32 & $256 / \geq 32$ & $1.8 \times 10^{4}$ \\
\hline 27. TT MeOH & 128 & $-/ \geq 128$ & $3.5 \times 10^{4}$ & 32 & $256 / \geq 32$ & $1.8 \times 10^{4}$ \\
\hline 28. $\mathrm{TT} \mathrm{H}_{2} \mathrm{O}$ & 128 & $-/ \geq 128$ & $4.2 \times 10^{4}$ & 32 & $256 / \geq 32$ & $1.7 \times 10^{4}$ \\
\hline 29. UD MeOH & 128 & $-/ \geq 128$ & $2.3 \times 10^{4}$ & 32 & $256 / \geq 32$ & $1.9 \times 10^{4}$ \\
\hline 30. UD $\mathrm{H}_{2} \mathrm{O}$ & 128 & $-/ \geq 128$ & $3.3 \times 10^{4}$ & 32 & $256 / \geq 32$ & $3.3 \times 10^{4}$ \\
\hline 31. VAA MeO & 128 & $-/ \geq 128$ & $2.8 \times 10^{4}$ & 32 & $256 / \geq 32$ & $2.8 \times 10^{4}$ \\
\hline 32. VAA $\mathrm{H}_{2} \mathrm{O}$ & 128 & $-/ \geq 128$ & $4.1 \times 10^{4}$ & 32 & $256 / \geq 32$ & $3.9 \times 10^{4}$ \\
\hline 33. VAC MeOH & 128 & $-/ \geq 128$ & $3.0 \times 10^{4}$ & 32 & $256 / \geq 32$ & $3.5 \times 10^{4}$ \\
\hline 34. VAC $\mathrm{H}_{2} \mathrm{O}$ & 128 & $-/ \geq 128$ & $1.8 \times 10^{4}$ & 32 & $256 / \geq 32$ & $2.0 \times 10^{4}$ \\
\hline Ampicillin & 0.12 & & & 1 & & \\
\hline Ciprofloxacin & 0.5 & & & 0.5 & & \\
\hline Gentamicin & 1 & & & 1 & & \\
\hline Vancomycin & 0.12 & & & - & & \\
\hline TMP-SMX & - & & & - & & \\
\hline
\end{tabular}

MeOH: methanolic extract; $\mathrm{H}_{2} \mathrm{O}$ : water extract 
Appendix 4. Antibacterial Activity of Extracts (1-34) and Controls

\begin{tabular}{|c|c|c|c|c|c|c|}
\hline \multirow[b]{3}{*}{ Extracts } & \multicolumn{6}{|c|}{ Gram positive } \\
\hline & \multicolumn{3}{|c|}{$\begin{array}{l}\text { Bacillus cereus } \\
\text { NRRL B-3711 }\end{array}$} & \multicolumn{3}{|c|}{$\begin{array}{c}\text { Bacillus subtilis } \\
\text { ATCC } 6633\end{array}$} \\
\hline & MIC & $\mathrm{MBC} / \mathrm{MBS}$ & $\mathrm{CFU} / \mathrm{mL}$ & MIC & $\mathrm{MBC} / \mathrm{MBS}$ & $\mathrm{CFU} / \mathrm{mL}$ \\
\hline 1. $\mathrm{AC} \mathrm{MeOH}$ & 64 & $-/ \geq 64$ & $4.7 \times 10^{3}$ & 128 & $256 / 128$ & \\
\hline 2. $\mathrm{AC} \mathrm{H}_{2} \mathrm{O}$ & 128 & $\geq 128 /-$ & - & 128 & $256 / 128$ & \\
\hline 3. $\mathrm{AM} \mathrm{MeOH}$ & 128 & $-/ \geq 128$ & TNC & 128 & $256 / 128$ & \\
\hline 4. $\mathrm{AM} \mathrm{H}_{2} \mathrm{O}$ & 256 & $-/ \geq 256$ & $3.5 \times 10^{3}$ & 128 & $256 / 128$ & \\
\hline 5. $\mathrm{CO} \mathrm{MeOH}$ & 128 & $-/ \geq 128$ & $5.4 \times 10^{3}$ & 128 & $256 / 128$ & \\
\hline 6. $\mathrm{CO} \mathrm{H}_{2} \mathrm{O}$ & 128 & $-/ \geq 128$ & TNC & 128 & $256 / 128$ & \\
\hline 7. $\mathrm{HP} \mathrm{MeOH}$ & 128 & $-/ \geq 128$ & TNC & 128 & $256 / 128$ & \\
\hline 8. $\mathrm{HP} \mathrm{H}_{2} \mathrm{O}$ & 128 & $-/ \geq 128$ & TNC & 64 & $128 / 64$ & \\
\hline 9. $\mathrm{ML} \mathrm{MeOH}$ & 128 & $-/ \geq 128$ & $1.6 \times 10^{3}$ & 64 & $128 / 64$ & \\
\hline 10. $\mathrm{ML} \mathrm{H}_{2} \mathrm{O}$ & 256 & $-/ \geq 128$ & $2.1 \times 10^{3}$ & 128 & $256 / 128$ & \\
\hline 11. $\mathrm{PR} \mathrm{MeOH}$ & 128 & $-/ \geq 128$ & $3.6 \times 10^{3}$ & 64 & $128 / 64$ & \\
\hline 12. $\mathrm{PR} \mathrm{H}_{2} \mathrm{O}$ & 128 & $-/ \geq 128$ & $2.0 \times 10^{3}$ & 64 & $128 / 64$ & \\
\hline 13. $\mathrm{RhC} \mathrm{MeOH}$ & 128 & $-/ \geq 128$ & $2.2 \times 10^{3}$ & 128 & $256 / 128$ & \\
\hline 14. $\mathrm{RhC} \mathrm{H}_{2} \mathrm{O}$ & 128 & $-/ \geq 128$ & TNC & 64 & $128 / 64$ & \\
\hline 15. $\mathrm{RoC} \mathrm{MeOH}$ & 128 & $-/ \geq 128$ & $2.8 \times 10^{3}$ & 128 & $256 / 128$ & \\
\hline 16. $\mathrm{RoC} \mathrm{H}_{2} \mathrm{O}$ & 256 & $-/ \geq 256$ & $3.7 \times 10^{3}$ & 128 & $256 / 128$ & \\
\hline 17. RoCG MeOH & 128 & $-/ \geq 128$ & $1.2 \times 10^{3}$ & 128 & $256 / 128$ & \\
\hline 18. RoCG $\mathrm{H}_{2} \mathrm{O}$ & 128 & $-/ \geq 128$ & $3.2 \times 10^{3}$ & 128 & $256 / 128$ & \\
\hline 19. RPF MeOH & 128 & $-/ \geq 128$ & $3.2 \times 10^{3}$ & 128 & $256 / 128$ & \\
\hline 20. $\mathrm{RPF} \mathrm{H}_{2} \mathrm{O}$ & 128 & $-/ \geq 128$ & $3.1 \times 10^{3}$ & 128 & $256 / 128$ & \\
\hline 21. RPL MeOH & 128 & $-/ \geq 128$ & $1.5 \times 10^{3}$ & 128 & $256 / 128$ & \\
\hline 22. $\mathrm{RPL} \mathrm{H}_{2} \mathrm{O}$ & 256 & $-/ \geq 256$ & $3.1 \times 10^{3}$ & 128 & $256 / 128$ & \\
\hline 23. TF MeOH & 128 & $-/ \geq 128$ & $2.1 \times 10^{3}$ & 128 & $256 / 128$ & \\
\hline 24. $\mathrm{TF} \mathrm{H}_{2} \mathrm{O}$ & 128 & $-/ \geq 128$ & $1.4 \times 10^{3}$ & 128 & $256 / 128$ & \\
\hline 25. TP MeOH & 128 & $-/ \geq 128$ & $6.2 \times 10^{3}$ & 128 & $256 / 128$ & \\
\hline 26. TP $\mathrm{H}_{2} \mathrm{O}$ & 128 & $-/ \geq 128$ & $7.3 \times 10^{3}$ & 128 & $256 / 128$ & \\
\hline 27. TT MeOH & 128 & $-/ \geq 128$ & $5.4 \times 10^{3}$ & 128 & $256 / 128$ & \\
\hline 28. $\mathrm{TT} \mathrm{H}_{2} \mathrm{O}$ & 256 & $-/ \geq 256$ & $4.2 \times 10^{3}$ & 128 & $256 / 128$ & \\
\hline 29. UD MeOH & 128 & $-/ \geq 128$ & $7.1 \times 10^{3}$ & 128 & $256 / 128$ & \\
\hline 30. UD $\mathrm{H}_{2} \mathrm{O}$ & 128 & $-/ \geq 128$ & $4.5 \times 10^{3}$ & 128 & $256 / 128$ & \\
\hline 31. VAA MeO & 128 & $-/ \geq 128$ & $3.6 \times 10^{3}$ & 128 & $256 / 128$ & \\
\hline 32. VAA $\mathrm{H}_{2} \mathrm{O}$ & 128 & $-/ \geq 128$ & $7.5 \times 10^{3}$ & 128 & $256 / 128$ & \\
\hline 33. VAC MeOH & 128 & $-/ \geq 128$ & $3.5 \times 10^{3}$ & 128 & $256 / 128$ & \\
\hline 34. VAC $\mathrm{H}_{2} \mathrm{O}$ & 256 & $-/ \geq 256$ & $4.4 \times 10^{3}$ & 128 & $256 / 128$ & \\
\hline Ampicillin & 0.12 & & & 0.12 & & \\
\hline Ciprofloxacin & 0.25 & & & 0.25 & & \\
\hline Gentamicin & 0.5 & & & 0.5 & & \\
\hline Vancomycin & - & & & - & & \\
\hline TMP-SMX & 0.25 & & & 0.12 & & \\
\hline
\end{tabular}

$\mathrm{MeOH}$ : methanolic extract; $\mathrm{H}_{2} \mathrm{O}$ : water extract

Empty cells denote lost plates. 


\section{JANNA LEANN ROSE}

July 20, 1978

May 2000

2000-2001

May 2005

2006-2011

2008

2008-2009

2010

2011

2011
Born, Scott Air Force Base, Illinois, USA

B.A. Biology and Anthropology

Double Major

Illinois Wesleyan University

Bloomington, Illinois

Laboratory Technician

Incyte Genomics, Inc.

St. Louis, Missouri

M.A., Socio-Cultural Anthropology

Tulane University

New Orleans, Louisiana

NIH MBRS/RISE Fellowship

Harvard Summer Botany Course

Fulbright Fellow, Turkey

Society for Economic Botany

Morton Award, Honorable Mention

Botanical Society of America

Graduate Student Award

Phytochemical Section

Women in Botany Award

\section{SELECTED PUBLICATIONS AND PRESENTATIONS}

Rose, Janna. 2011. In Press. The Talloires Declaration: Global Networking and Local Action. Chapter in Deborah Gallagher (Ed.) Environmental Leadership: A Reference Handbook. Sage Publications, Thousand Oaks, CA.

Rose, Janna. 2010. Antibacterial and Cytotoxic Properties of Turkish Anti-Diarrheal Plants. MBRS RISE \& MARC U*STAR Student Symposium, Miami, FL: November 4-5, 2010. 
Rose, Janna. 2010. Bactericidal and Bacteriostatic Properties of Crude Extracts from Rural Turkish Anti-Diarrheal Plants. ICAAC-Interscience Conference on Antimicrobial Agents and Chemotherapy, Boston, MA: September 12-15, 2010.

Rose, Janna. 2010. The Reported Use of Dog Rose Galls (Rosa canina L.) to Treat Human Gastroenteritis. Botanical Society of America, Providence, RI: August 15,2010 .

Rose, Janna, Sema Demir, Evrim Özunel, and Brad Bennett. 2010. Concepts of Gastrointestinal Disease and its Treatment among Rural Turkish Villagers. Society for Economic Botany Annual Meeting, Xalapa, Veracruz, Mexico: June 6-10, 2010. Awarded Honorable Mention for Society's Morton Award.

Rose, Janna, Ílhan Gürbüz, Berrin Özçelik, and Brad Bennett. 2010. Bactericidal and Bacteriostatic Effects of 15 Anti-Diarrheal Plants from Central Anatolia. Society for Economic Botany Annual Meeting, Xalapa, Veracruz, Mexico: June 6-10, 2010. 